Prepared in cooperation with the Alaska Energy Authority

\title{
Effects of Ice Formation on Hydrology and Water Quality in the Lower Bradley River, Alaska-Implications for Salmon Incubation Habitat
}

Water-Resources Investigations Report 98-4191

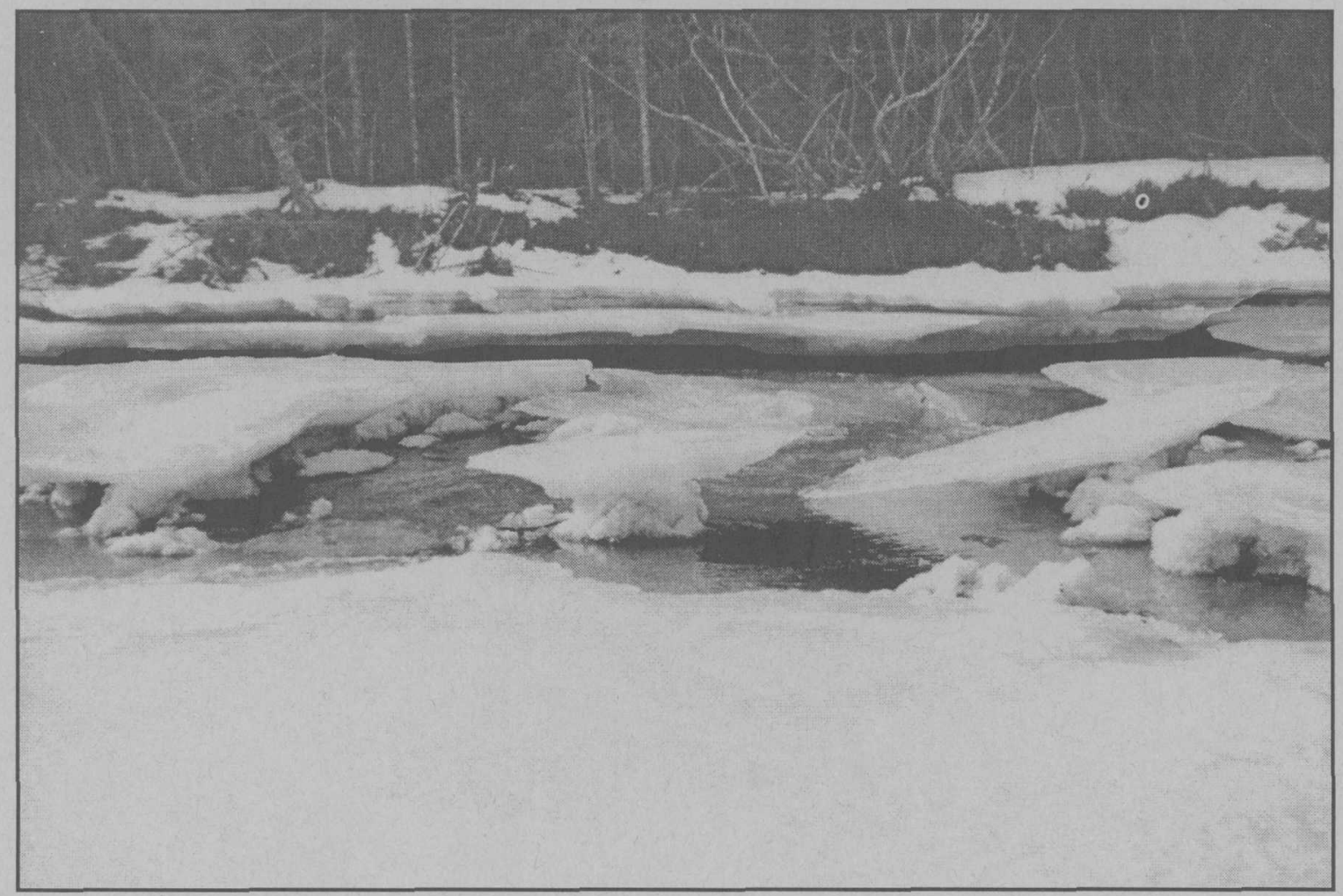

U.S. Department of the Interior U.S. Geological Survey 
Cover photograph: Ice pedestals at Bradley River near Tidewater transect, February 28, 1995. 


\section{Effects of Ice Formation on Hydrology and Water Quality in the Lower Bradley River, Alaska- Implications for Salmon Incubation Habitat}

by Ronald L. Rickman

U.S. GEOLOGICAL SURVEY

Water-Resources Investigations Report 98-4191

Prepared in cooperation with the ALASKA ENERGY AUTHORITY 


\section{U.S. DEPARTMENT OF THE INTERIOR \\ BRUCE BABBITT, Secretary}

U.S. GEOLOGICAL SURVEY

Thomas J. Casadevall, Acting Director

Use of trade names in this report is for identification purposes only and does not constitute endorsement by the U.S. Geological Survey.

For additional information:

District Chief

U.S. Geological Survey 4230 University Drive, Suite 201 Anchorage, AK 99508-4664

http://www-water-ak.usgs.gov
Copies of this report may be purchased from:

U.S. Geological Survey

Branch of Information Services

Box 25286

Denver, CO 80225-0286 


\section{CONTENTS}

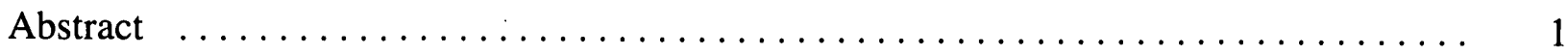

Introduction $\ldots \ldots \ldots \ldots \ldots \ldots \ldots \ldots \ldots \ldots \ldots \ldots \ldots \ldots \ldots \ldots \ldots$

Location of Study Area $\ldots \ldots \ldots \ldots \ldots \ldots \ldots \ldots \ldots \ldots \ldots \ldots \ldots \ldots \ldots$

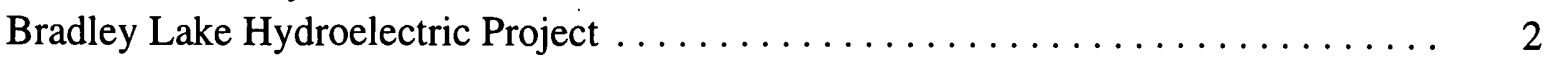

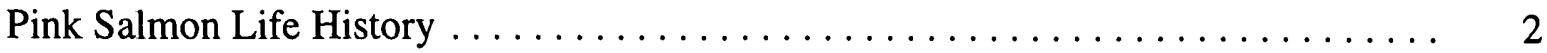

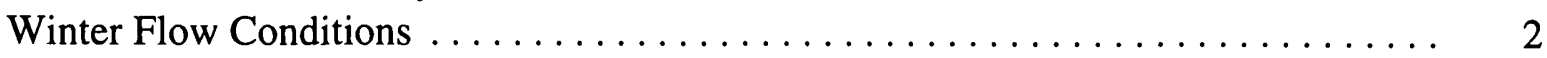

Purpose and Scope. . . . . . . . . . . . . . . . . . . . . . . . . 4

Acknowledgments . . . . . . . . . . . . . . . . . . . . . . . 4

Description of Study Area . . . . . . . . . . . . . . . . . . . . . . . . 4

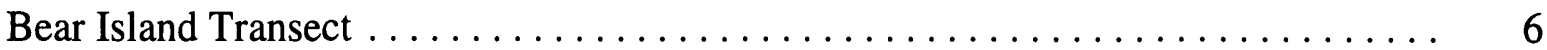

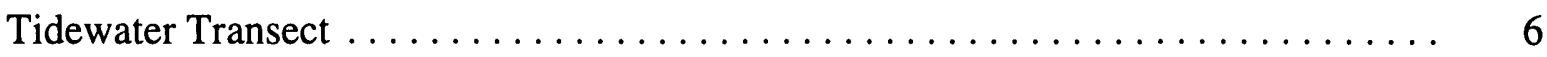

Tree Bar Reach Transect . . . . . . . . . . . . . . . . . . . . . . . . . . . . 6

Below Fish Camp Transect $\ldots \ldots \ldots \ldots \ldots \ldots \ldots \ldots \ldots \ldots \ldots \ldots \ldots \ldots \ldots$

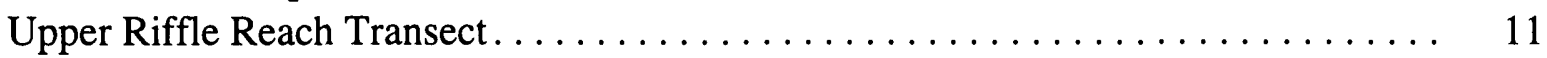

Lower Riffle Reach Transect. . . . . . . . . . . . . . . . . . . . . . . 11

Middle Fork Bradley River below North Fork Bradley River . . . . . . . . . . . . . . 14

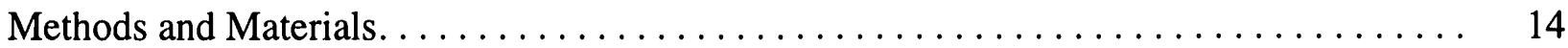

Observation of Spawning Area Locations and Escapement Estimates . . . . . . . . . 14

Measurements of Surface Water . . . . . . . . . . . . . . . . . . . . . . . . 14

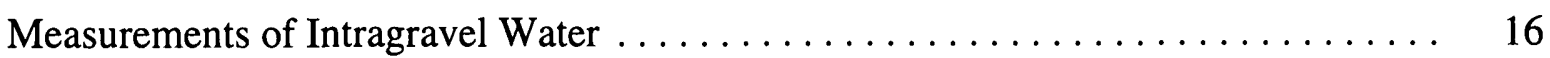

Observations and Estimates of Fine-Sediment Deposition $\ldots \ldots \ldots \ldots \ldots \ldots$

Results and Discussion $\ldots \ldots \ldots \ldots \ldots \ldots \ldots \ldots \ldots \ldots \ldots \ldots \ldots \ldots$

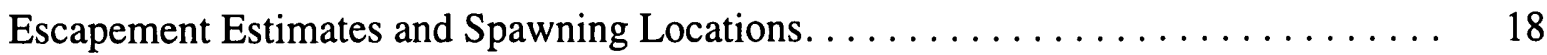

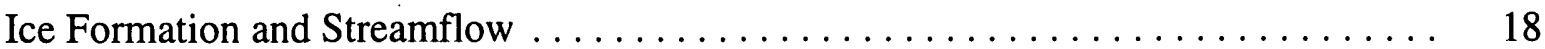

Hydrologic Properties . . . . . . . . . . . . . . . . . . . . . . 23

Surface-Water Hydrostatic Head and Water Depth . . . . . . . . . . 23

Surface-Water Velocity. . . . . . . . . . . . . . . . . . . . . 24

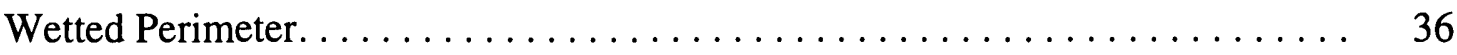

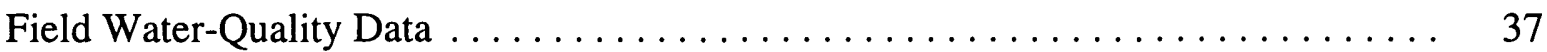

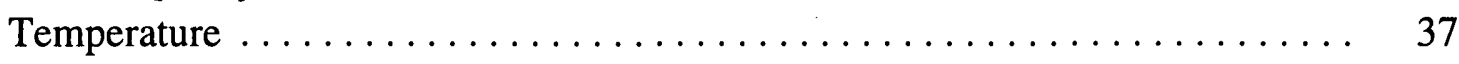

Dissolved Oxygen. . . . . . . . . . . . . . . . . . . . . . . . . 38

Specific Conductance .......................... 40

Fine-Sediment Deposition and Streambed Permeability. . . . . . . . . . . . 40

Fine-Sediment Deposition. . . . . . . . . . . . . . . . 40

Dissolved-Oxygen Interchange . . . . . . . . . . . . . . . . 42

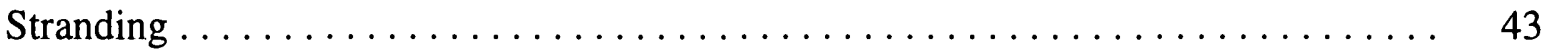

Discharge from the North and Lower Middle Forks Bradley River . . . . . . . . . 45

Summary $\ldots \ldots \ldots \ldots \ldots \ldots \ldots \ldots \ldots \ldots \ldots \ldots \ldots \ldots \ldots \ldots \ldots \ldots \ldots$

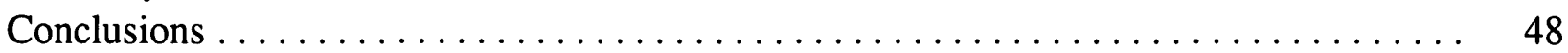

References Cited . . . . . . . . . . . . . . . . . . . . . . . . . . . . . . 49 


\section{FIGURES}

1. Map showing location of Bradley Lake Hydroelectric Project area........... VI

2. Photograph showing aerial view of the study area from Bear Island to Lower Riffle Reach................................ 4

3. Map showing lower Bradley River study cross-section transects .......... 5

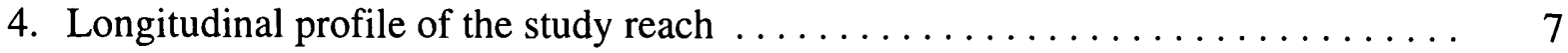

5-10. Photographs showing Bradley River at the:

5. Bear Island transect looking upstream $\ldots \ldots \ldots \ldots \ldots \ldots \ldots \ldots \ldots \ldots$

6. Tidewater transect. ................................. 9

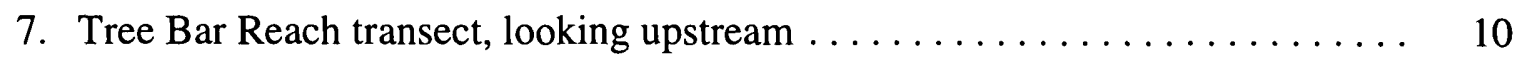

8. Below Fish Camp transect, looking upstream ................ 12

9. Upper Riffle Reach transect, looking upstream ................ 13

10. Lower Riffle Reach transect......................... 15

11. Diagram showing definitions of water depth and hydrostatic head as

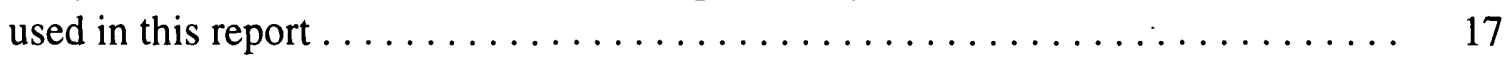

12. Graph of estimated escapement for pink salmon, 1986 to $1997 . \ldots \ldots \ldots \ldots \ldots$

13. Graph showing daily mean discharges for Bradley River near Tidewater...... 20

14. Photograph of water flowing out of holes drilled through the ice during

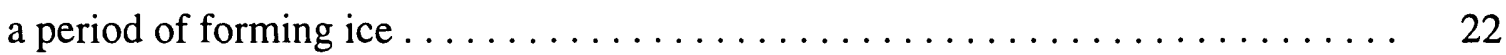

15-20. Graphs showing selected physical properties of Bradley River relative to discharge:

15. At Bear Island transect . . . . . . . . . . . . . . . . . . . . . . . 25

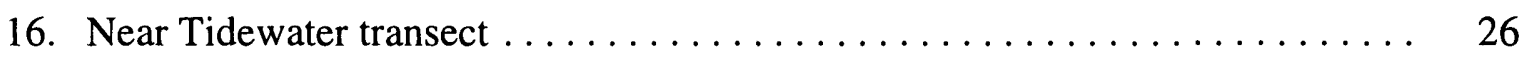

17. At Tree Bar Reach transect............................. 27

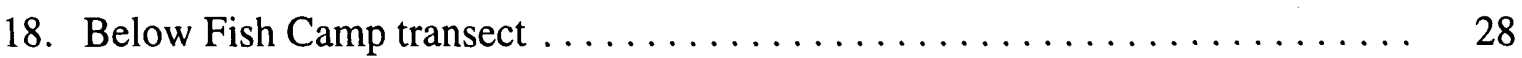

19. At Upper Riffle Reach transect. . . . . . . . . . . . . . . . . . . . 29

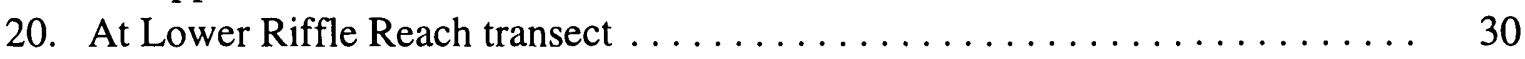

21-22. Graphs showing:

21. Lines of equal velocity for selected ice-forming and ice-free conditions for Bradley River at Tree Bar Reach . .................. 32

22. Selected surface-water velocity distributions for the six transects in the

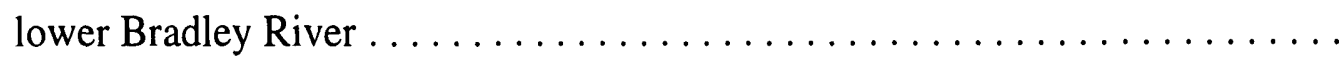

23-24.Boxplots showing:

23. Surface- and intragravel-water dissolved-oxygen concentrations at the six transects of the lower Bradley River. . . . . . . . . . . . . . . . .

24. Dissolved-oxygen percent interchange at the six transects of the lower

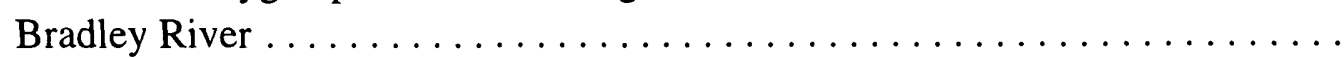

25. Graphs showing instantaneous discharge measurements and daily mean discharges for the Middle Fork Bradley River below North Fork Bradley River ... 


\section{TABLES}

1. Summary of ice formation at stream-gaging station Bradley River near Tidewater .

2. Ice conditions for which mean velocity is likely to exceed 0.5 foot per second for various discharges. . . . . . . . . . . . . . . . . . . . . .

3. Mean intragravel-water temperature and thermal input from January 1 to April 1.

4. Standard settling velocities for quartz particles and corresponding minimum shear velocities required to keep particles in suspension . . . . . . . . . . . . .

5. Mean and range of shear velocities for the six study transects in the lower Bradley River . . . . . . . . . . . . . . . . . . . . . . . . . . .

6. Gravel bar slopes at the six study transects . . . . . . . . . . . . . . .

7. Monthly minimum discharge measured at stream-gaging station Middle Fork Bradley River below North Fork Bradley River and estimated monthly maximum discharge needed from the fish-water bypass to meet minimum flow requirements in the lower Bradley River. . . . . . . . . . . .

\section{CONVERSION FACTORS, ABBREVIATED WATER-QUALITY UNITS AND VERTICAL DATUM}

\begin{tabular}{rll}
\hline Multiply & by & To obtain \\
\hline $\operatorname{inch}(\mathrm{in})$. & 25.4 & millimeter \\
foot $(\mathrm{ft})$ & 0.3048 & meter \\
mile $(\mathrm{mi})$ & 1.609 & kilometer \\
foot per second $(\mathrm{ft} / \mathrm{s})$ & 0.3048 & meter per second \\
foot per minute $(\mathrm{ft} / \mathrm{min})$ & 0.3048 & meter per minute \\
cubic foot per second $\left(\mathrm{ft}^{3} / \mathrm{s}\right)$ & 0.02832 & cubic meter per second \\
foot per second squared $\left(\mathrm{ft} / \mathrm{s}^{2}\right)$ & 0.3048 & meter per second squared \\
\hline
\end{tabular}

In this report, temperature is reported in degrees Celsius $\left({ }^{\circ} \mathrm{C}\right)$, which can be converted to degrees Fahrenheit $\left({ }^{\circ} \mathrm{F}\right)$ by the following equation:

$$
{ }^{\circ} \mathrm{F}=1.8\left({ }^{\circ} \mathrm{C}\right)+32
$$

\section{ABBREVIATED WATER-QUALITY UNITS}

$\mathrm{mL}$, milliliter

$\mathrm{mg} / \mathrm{L}$, milligram per liter

$\mathrm{mm}$, millimeter

$\mu \mathrm{S} / \mathrm{cm}$, microsiemen per centimeter at 25 degrees Celsius

\section{VERTICAL DATUM}

Sea level: In this report, "sea level" refers to the National Geodetic Vertical Datum of 1929-A geodetic datum derived from a general adjustment of the first-order level nets of the United States and Canada, formerly called Sea Level Datum of 1929. 

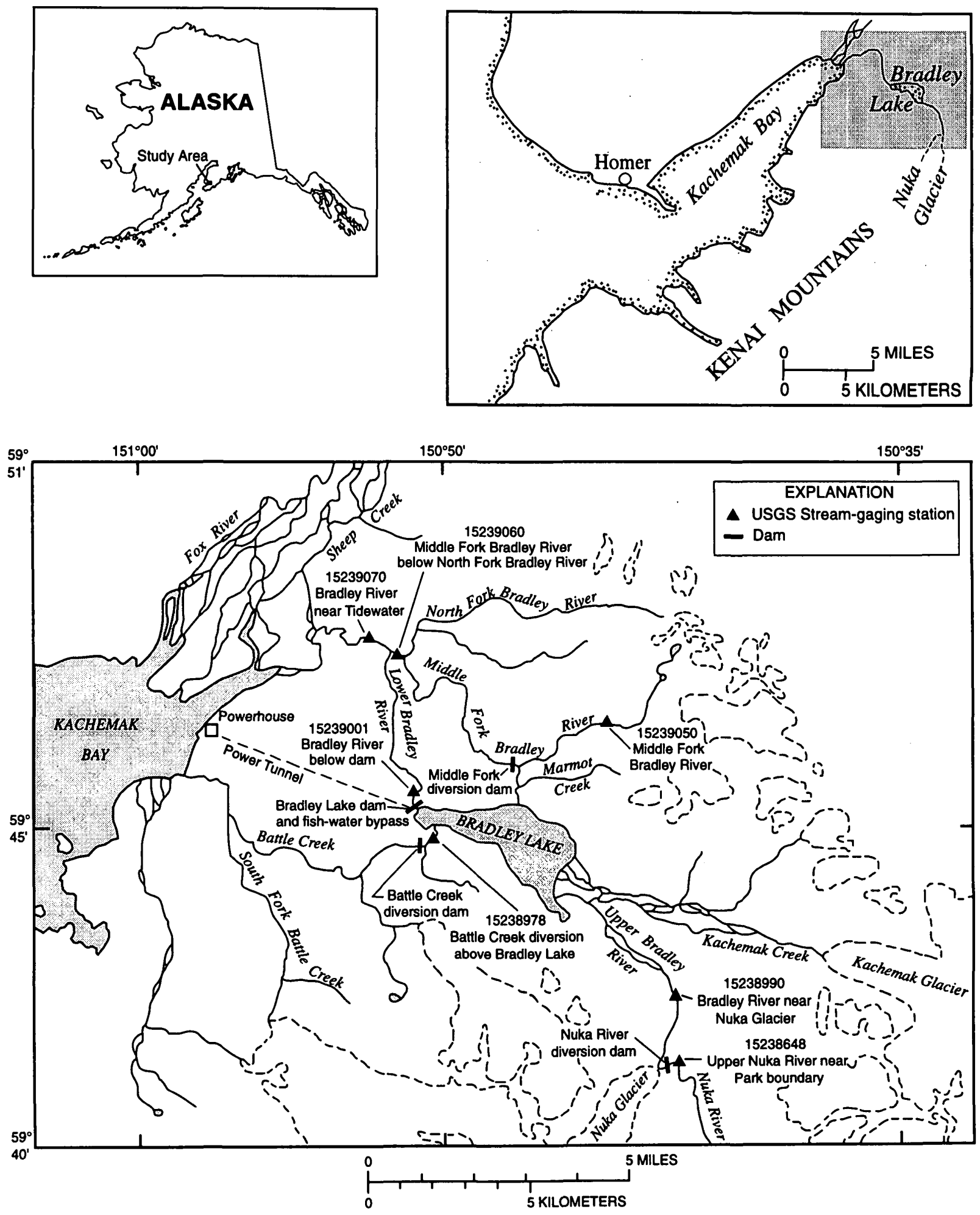

Figure 1. Location of the Bradley Lake Hydroelectric Project area. 


\title{
Effect of Ice Formation on Hydrology and Water Quality in the Lower Bradley River, Alaska-Implications for Salmon Incubation Habitat
}

\author{
By Ronald L. Rickman
}

\begin{abstract}
Previous studies of streamflow in the lower Bradley River near Homer, Alaska, have shown that a minimum flow of 40 cubic feet per second is required from November 2 to April 30 to ensure adequate habitat for salmon incubation. The flow regime of the lower Bradley River was reevaluated in a U.S. Geological Survey study to determine the effects of ice formation on salmon habitat.
\end{abstract}

The limiting factor for determining the minimal acceptable flow in the lower Bradley River appears to be stream-water velocity. The minimum short-term flow needed to ensure adequate salmon incubation habitat when ice is present is about 30 cubic feet per second. For long-term flows, 40 cubic feet per second is adequate when ice is present. Long-term minimum discharge needed to ensure adequate incubation habitat-which is based on mean velocity alone-is as follows: 40 cubic feet per second when ice is forming; 35 cubic feet per second for stable and eroding ice conditions; and 30 cubic feet per second for ice-free conditions. The effects of long-term streamflow less than 40 cubic feet per second on fine-sediment deposition and dissolved-oxygen interchange could not be extrapolated from the data.

Hydrologic properties and water-quality data were measured in winter only from March 1993 to April 1998 at six transects in the lower Bradley River under three phases of icing: forming, stable, and eroding. Discharge in the lower Bradley River ranged from 33 to 73 cubic feet per second during all phases of ice formation and ice conditions, which ranged from ice free to 100 percent ice cover. Hydrostatic head was adequate for habitat protection for all ice phases and discharges. Mean stream velocity was adequate for all but one ice-forming episode. Velocity distribution within each transect varied significantly from one sampling period to the next. No relation was found between ice phase, discharge, and wetted perimeter. Intragravel-water temperature was slightly warmer than surface-water temperature. Surface- and intragravel-water dissolved-oxygen levels were adequate for all ice phases and discharges. No apparent relation was found between dissolved-oxygen levels and streamflow or ice conditions. Fine-sediment deposition was greatest at the downstream end of the study reach because of low shear velocities and tideinduced deposition. Dissolved-oxygen interchange was adequate for all discharges and ice conditions. Stranding potential of salmon fry was found to be low throughout the study reach. Minimum flows from the fish-water bypass needed to maintain 40 cubic feet per second in the lower Bradley River are estimated.

\section{INTRODUCTION}

\section{Location of Study Area}

The Bradley River originates in the Kenai Mountains east of Homer, Alaska, and flows into Bradley Lake (fig. 1), then flows northward from Bradley Lake for about 5 mi to Kachemak Bay. The Middle and North Forks of the Bradley River flow into the main stem of the Bradley 
River $3.3 \mathrm{mi}$ downstream from the Bradley Lake outlet. Flow from the upper basin of the Middle Fork is diverted into Bradley Lake. About $5.5 \mathrm{mi}$ of the lower Bradley River are accessible to fish; the upper $1.5 \mathrm{mi}$ provide spawning habitat for salmon and Dolly Varden char; however numerous waterfalls prevent fish from moving farther upstream.

\section{Bradley Lake Hydroelectric Project}

The Alaska Energy Authority (AEA) began operation of the Bradley Lake Hydroelectric Project near Homer in 1991 (fig. 1). The dam, which was constructed at the Bradley Lake outlet, incorporates a fish-water bypass system to maintain flows required for fish habitat enhancement in the lower Bradley River. Project operation has resulted in reduced streamflow in the lower Bradley River during the summer, and increased flow above natural conditions during the winter (Rickman, 1993), thus stabilizing and probably improving salmon spawning and rearing habitat (Morsell and Howard, 1995).

Federal Energy Regulatory Commission (FERC) licensing requirements for the Bradley Lake Hydroelectric Project require maintenance of a minimum flow of $40 \mathrm{ft}^{3} / \mathrm{s}$ from November 2 to April 30, as measured at the U.S. Geological Survey's (USGS) stream-gaging station Bradley River near Tidewater (station No. 15239070). This recommended discharge of $40 \mathrm{ft}^{3} / \mathrm{s}$ is based on an open-water (ice-free) instream flow study conducted by a private consultant (Woodward-Clyde Consultants, 1983). The instream flow study was focused primarily on the egg incubation requirements of pink salmon (Oncorhynchus gorbuscha), but other salmon species and Dolly Varden char habitat requirements were also addressed. The study found little difference in usable egg incubation habitat between flows of 30 and $40 \mathrm{ft}^{3} / \mathrm{s}$, but did not account for the effects of river ice formation, which is common in the lower Bradley River during the winter months. River ice significantly alters the flow regime, which may adversely affect incubation habitat. Many studies have developed suitability criteria for salmon spawning habitats, but few have addressed salmon incubation habitats in ice-covered streams (Morsell, 1994). The embryos and alevins (recently hatched fry) are essentially immobile, so it is important that the egg incubation habitat remain healthy throughout the winter (Rundquist and Baldrige, 1990, p. 591). Hydrologic and water-quality characteristics important to the incubation process include stream velocity, depth of surface water, hydrostatic head, wetted perimeter, intragravelwater temperature, intragravel dissolved oxygen, specific conductance, and streambed stability and permeability.

\section{Pink Salmon Life History}

Pink salmon move into the lower Bradley River to spawn from mid-July to early September, with the spawning peak occurring at about mid-August (Morsell and others, 1993). The female digs a nest (redd) in the stream gravels, lays the eggs at an average depth of approximately 12 in., and covers them with gravel. The eggs hatch sometime in mid-winter and alevins remain in the gravel until early spring (John Morsell, Northern Ecological Services, oral. commun., 1995). The lower Bradley River has ice formation during much of the egg incubation, hatching, and alevin development stages. The exact time of alevin emergence from the gravels in the lower Bradley River is unknown, but is suspected to be from late March to early May. Pink salmon fry do not spend much time in the river and migrate soon after emergence. Pink salmon have a fixed 2-year life cycle-as a result, odd and even year populations are reproductively isolated from each other.

\section{Winter Flow Conditions}

Ice formation in the lower Bradley River may cause backwater conditions that increase the wetted perimeter and depth of surface 
water. Complete ice cover can result in pressurized flow (closed-conduit flow) and a corresponding increase of hydrostatic head. Stream velocity may decrease, which can adversely affect dissolved-oxygen levels in surface and intragravel waters. Anchor ice-ice that forms on the streambed-may retard water and dissolved-oxygen interchange between surface and intragravel environments.

Periodic temporary dewatering of the lower Bradley River could potentially occur because of ice jamming upstream, or because of problems with the fish-water bypass system. Rapid dewatering of the stream channel may leave juvenile salmon stranded, thus killing them. Stranding frequency is inversely proportional to the slope of the dewatered gravel bars (Prewitt and Whitmus, 1986). Expansive, flat bars are associated with higher stranding rates than steeper bars, because fish may not be able to swim fast enough to remain in the water during rapid declines in stage.

Technicians operating the hydropower project require accurate streamflow information to maintain a minimum flow of $40 \mathrm{ft}^{3} / \mathrm{s}$ in the lower Bradley River. To provide this information, the stage of the river is measured continuously by the USGS, and the stage data are then converted to discharge by a mathematical correlation of stage and discharge (Rantz and others, 1982). This correlation is determined by periodic measurements of both stage and discharge, and remains valid as long as the channel geometry does not change. During the winter, however, the channel geometry changes significantly as ice forms on the banks, at the channel bottom, and on the water surface. As ice forms and disappears, the stage-discharge relation becomes invalid. As a result, hydropower operators have unreliable streamflow data during the winter low-flow season, which is when the need for accurate streamflow data is most critical.

In March 1993, under a cooperative agreement with the Alaska Energy Authority, the USGS began a 3-year study of winter flow conditions in the lower Bradley River. Northern Ecological Services, under contract with the Alaska Energy Authority, has monitored salmon escapement in the lower Bradley River (Morsell and others, 1993; Morsell, 1994, 1996, 1997) throughout this study. During this initial study, March 1993 to April 1995, operators of the Bradley hydroelectric project released flows of $40 \mathrm{ft}^{3} / \mathrm{s}$ at the fish-water bypass (measured at the USGS gaging station No. 15239001, "Bradley River below dam," which generally remains ice free) to ensure maintenance of a flow of $40 \mathrm{ft}^{3} / \mathrm{s}$ in the lower Bradley River. However, actual flows in the lower Bradley River were significantly higher than the target flow of $40 \mathrm{ft}^{3} / \mathrm{s}$ because of inflow from the Middle and North Forks Bradley River. Flow averaging $57 \mathrm{ft}^{3} / \mathrm{s}$ during the initial 3 -year study (Rickman, 1996) made it impossible to predict hydrologic and water-quality effects at flows of $40 \mathrm{ft}^{3} / \mathrm{s}$ or less. Under agreement with the Alaska Energy Authority, the study was extended another 3 years (November 1995 to April 1998) with two changes to project operation: (1) water release at the fish-water bypass was reduced to $35 \mathrm{ft}^{3} / \mathrm{s}$, and (2) a stream-gaging station (No. 15239060) was installed at the Middle Fork Bradley River below North Fork Bradley River (fig. 1).

The objectives of this most recent study were to: (1) determine whether the minimum allowable flow of $40 \mathrm{ft}^{3} / \mathrm{s}$ from November 2 to April 30 provides adequate salmon incubation habitat protection during periods when ice is present in the river, and whether a lesser flow provides adequate protection; (2) provide estimates of the minimum limits of flow during periods of ice effect that would assure egg protection in the event of unexpected temporary decreases in flow below the allowable minimum; and (3) determine the discharges that must be released at the fish-water bypass to maintain $40 \mathrm{ft}^{3} / \mathrm{s}$ in the lower Bradley River. 


\section{Purpose and Scope}

This report describes the effects of ice on streamflow regime and water-quality characteristics for a range of streamflows that are important for the maintenance of salmon incubation habitat. The report also discusses the hydrologic properties and water-quality characteristics that are the most limiting for maintaining habitat. These data were then used to estimate the lower limits of flow that would ensure adequate salmon incubation habitat. The study was done at six transects in the lower Bradley River for the periods March 1993 through April 1994, and November through April 1994-98. Stranding potential at each of the six transects, and flow contributions from the Middle Fork Bradley River below the North Fork Bradley River are presented. Previously published hydrologic and water-quality data collected from March 1993 through April 1994 and from November through April 1994-98 are summarized (Rickman, 1995, 1996, and 1998).

\section{Acknowledgments}

The author gratefully acknowledges the assistance of John Morsell, of Northern Ecological Services (under contract with the Alaska Energy Authority), for assisting with field studies and providing salmon escapement information.

\section{DESCRIPTION OF STUDY AREA}

An oblique aerial view of the study area is shown in figure 2. Six transects were selected at known spawning areas of pink salmon (Morsell and others, 1993) in the lower Bradley River between Bear Island and Lower Riffle Reach (fig. 3). Transect markers from the WoodwardClyde instream flow study (1983) were

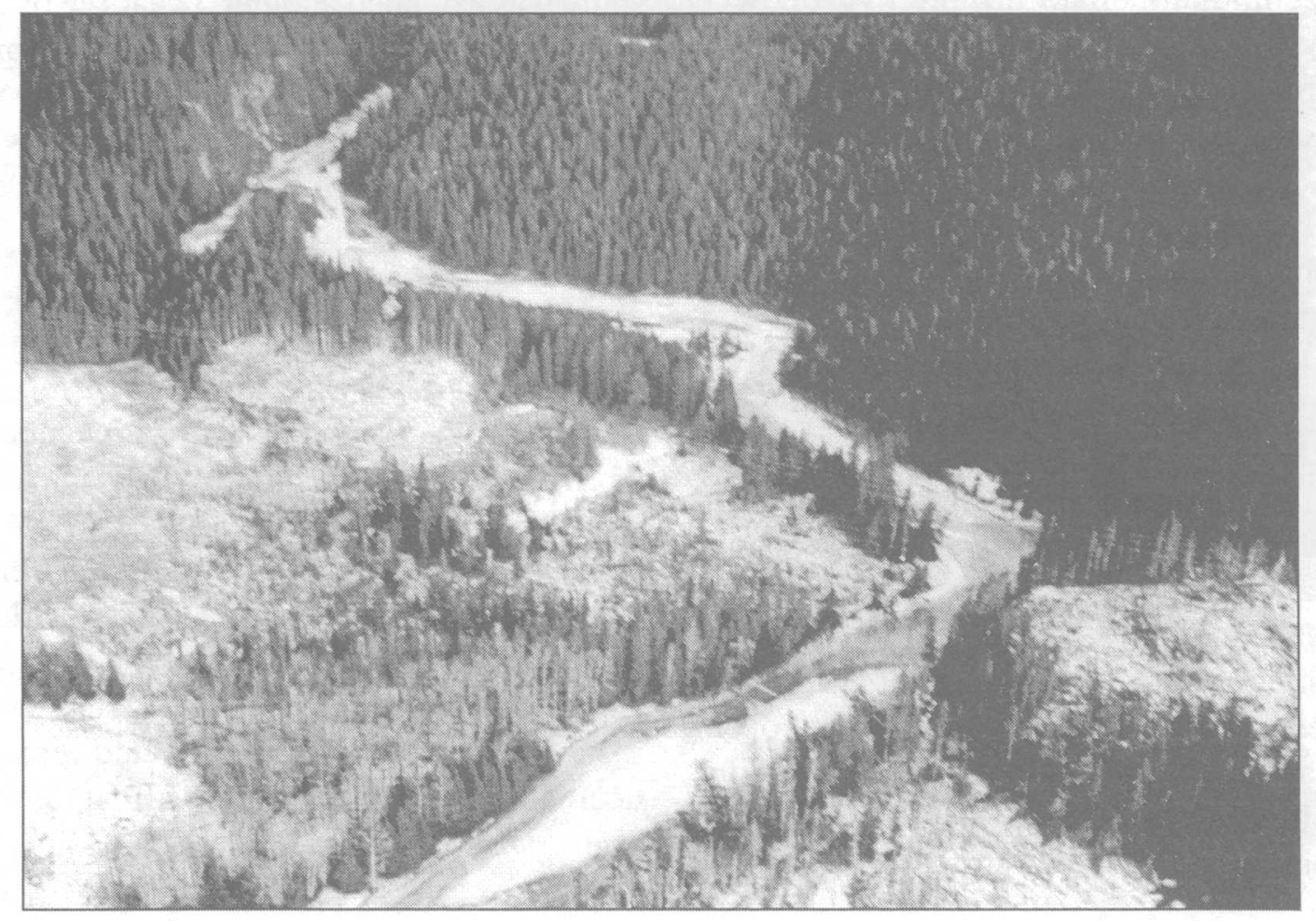

Figure 2. Aerial view of the study area on the lower Bradley River from Bear Island (upper left) to Lower Riffle Reach (bottom center). 


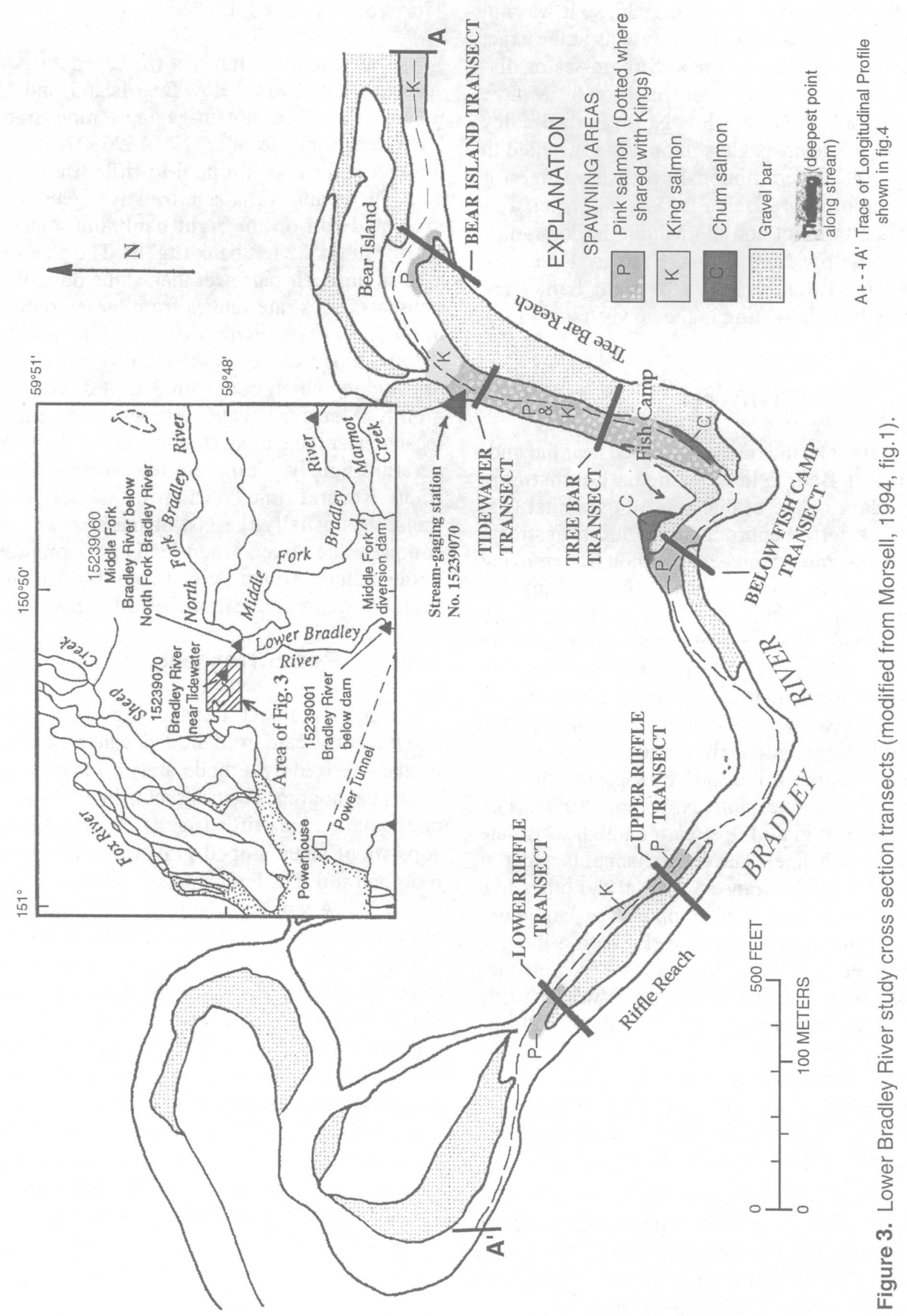


destroyed during a flood in 1986, so it was not possible to locate the new transects at the exact locations as the old ones. Stream-water discharge measurements were made on the Middle Fork Bradley River below North Fork Bradley River. A stream-gaging station was installed in July 1996 to continuously measure stage for computation of discharge. Site characteristics of each transect and the Middle Fork Bradley River below North Fork Bradley River are described below (left and right banks are defined when looking in the downstream direction).

\section{Bear Island Transect}

Bear Island transect, located near the midpoint of Bear Island, is near the upstream boundary of the usable spawning habitat (fig. 3). A waterfall approximately $500 \mathrm{ft}$ upstream from this transect prevents salmon from moving farther upstream. The transect is at a transition from pool to riffle (fig. 4) and is characterized by shallow sloped gravel bars on both right and left banks (fig. 5). The riffle has been steadily migrating upstream at a rate of less than one foot per year. A small narrow gravel bar near the right bank splits the river into two channels; a small portion of the total flow passed through the right channel until November 1996 when the riffle migrated upstream enough to isolate the right channel. The river channel is wider at the Bear Island transect than at the other five transects. Substrate is composed of large cobbles to medium-sized gravels, with a median diameter of $0.22 \mathrm{ft}$. Rickman (1996) erroneously reported that this transect was not tide affected-this transect is affected by high tide on rare occasions. Complete ice cover occurs several times each winter (fig. 4); however, it occurs less frequently here than at the other transects. A lead $10 \mathrm{ft}$ downstream from this transect remains open all winter.

A slough with a small stream is located approximately halfway between the Bear Island and the Tidewater transects. This slough is an important rearing habitat for coho salmon (Oncorhynchus kisutch) (Morsell, 1996).

\section{Tidewater Transect}

The Tidewater transect (fig. 3) is located approximately $100 \mathrm{ft}$ below Bear Island, and 35 ft below the USGS stream-gaging station Bradley River near Tidewater (No. 15239070). The transect is located at a pool-to-riffle transition area (fig. 4), and is characterized by a steep root mass and soil on the right bank and a steep gravel bar on the left bank (fig. 6). The channel at this transect is narrower than at the other five transects. Substrate ranges from large cobbles to medium gravel with a median diameter of $0.26 \mathrm{ft}$. This transect is affected by extremely high tides, which occur on 3 to 8 days each month. A surface-water temperature sensor located near the gaging station records the temperature hourly. Complete ice cover (fig. 6) occurs several times during the winter. This transect is usually the last of the six to form complete ice cover. Open leads are common throughout the winter. A lead $20 \mathrm{ft}$ downstream from this transect remains open all winter.

\section{Tree Bar Reach Transect}

Tree Bar Reach transect (fig. 3), located $280 \mathrm{ft}$ downstream from the Tidewater transect, is characterized by a moderately wide channel with a flat bottom. The transect is located in the midpoint of a long riffle (fig. 4). The right bank consists of steep sloped gravel overlain with roots and soil. The left bank is a relatively steep gravel bar. A small abandoned overflow channel is located along a bedrock wall on the far left side of the Bradley River flood plain. Substrate ranges from medium cobbles to medium gravel with a median diameter of $0.10 \mathrm{ft}$. This transect is affected by extremely high tides on 5 to 11 days each month. An intragravel temperature sensor, buried to a depth of $1 \mathrm{ft}$ below the streambed, is located $10 \mathrm{ft}$ downstream from this transect. Complete ice cover (fig. 7) occurs numerous times during the winter. Ice is occasionally broken up and rafted during high tide cycles. This occurs only if the ice has been weakened by warm air temperatures. 


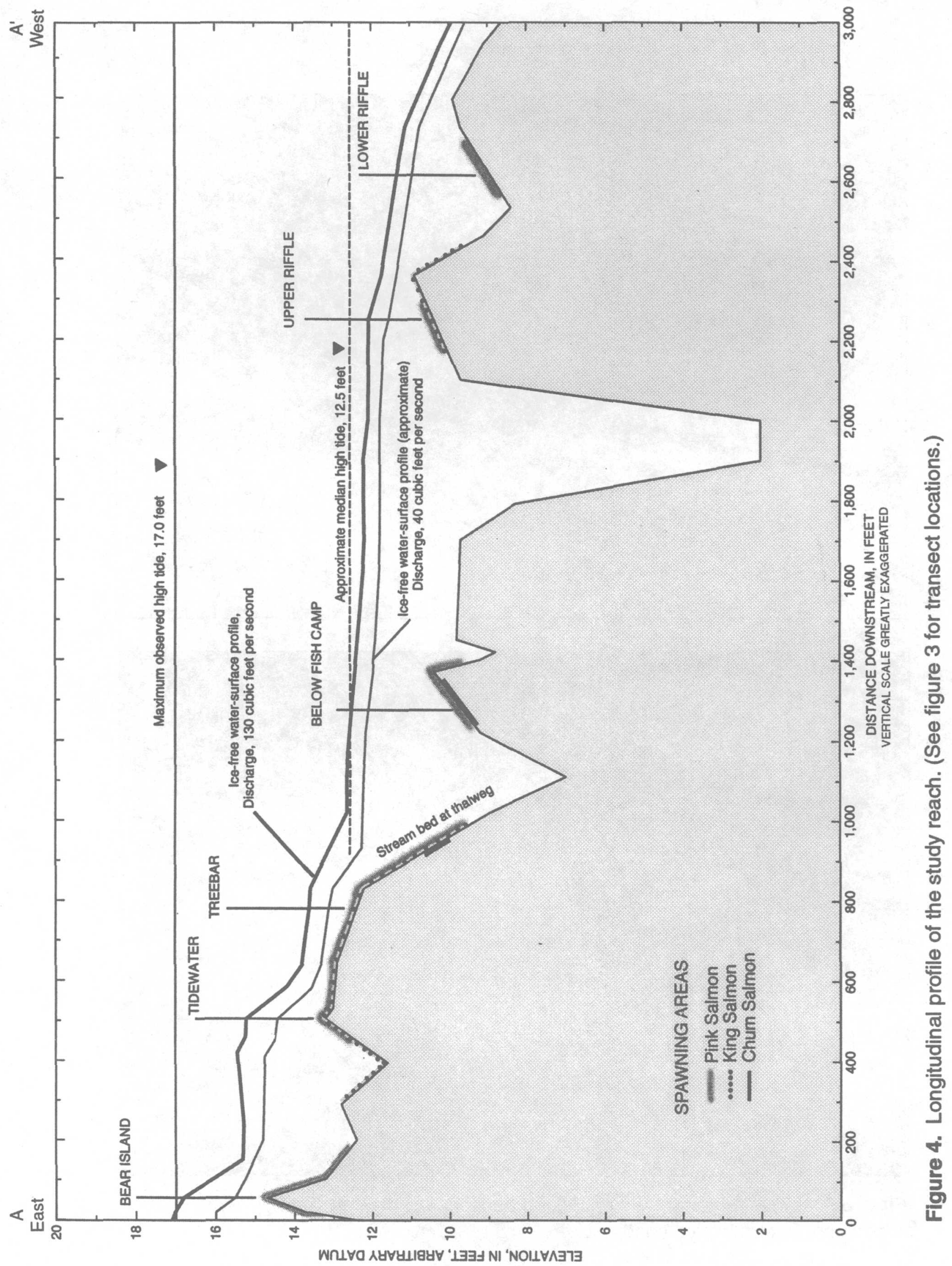

Description of Study Area 7 

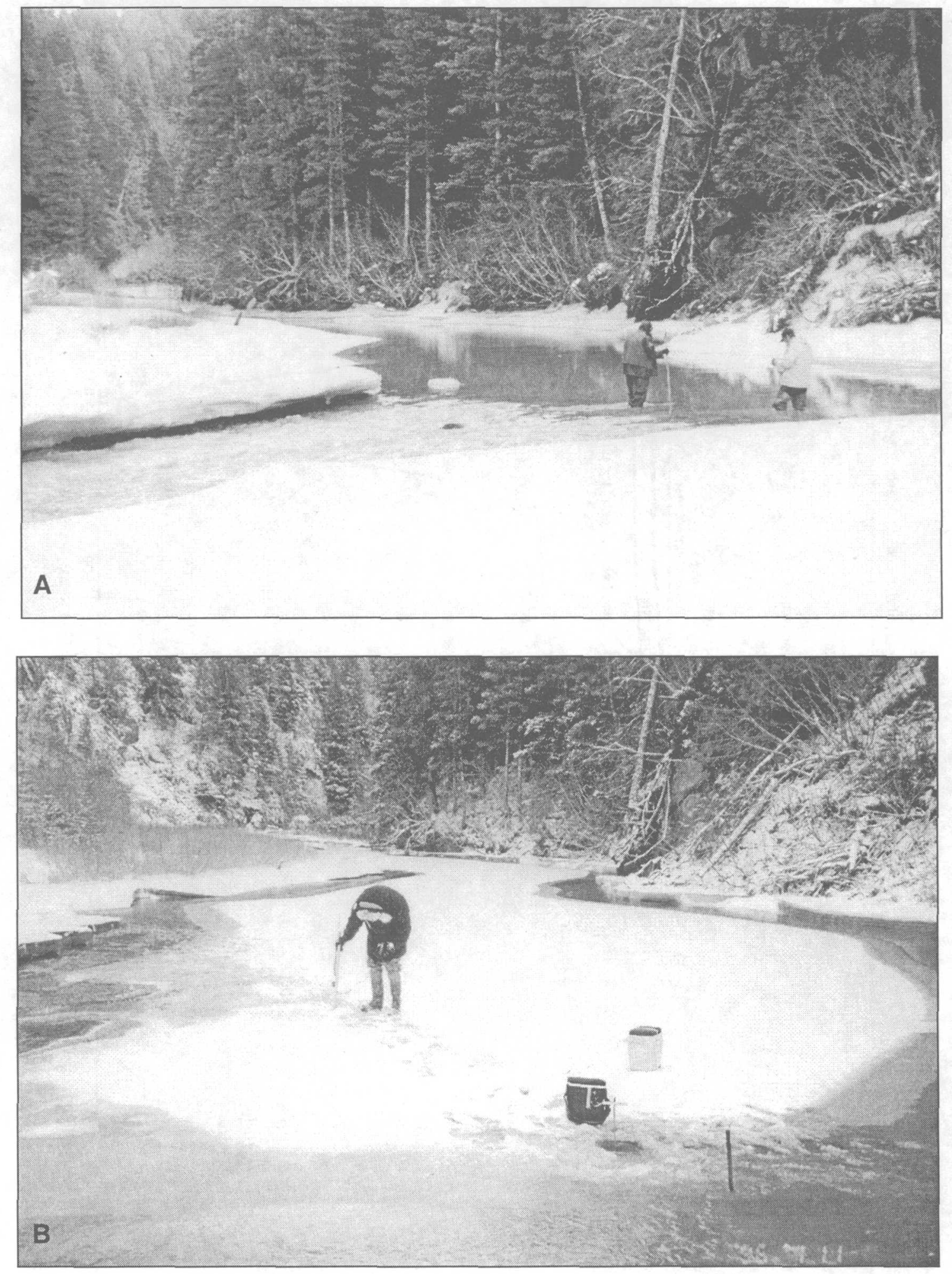

Figure 5. Bradley River at the Bear Island transect looking upstream: A, eroding ice conditions; B, forming ice conditions. 

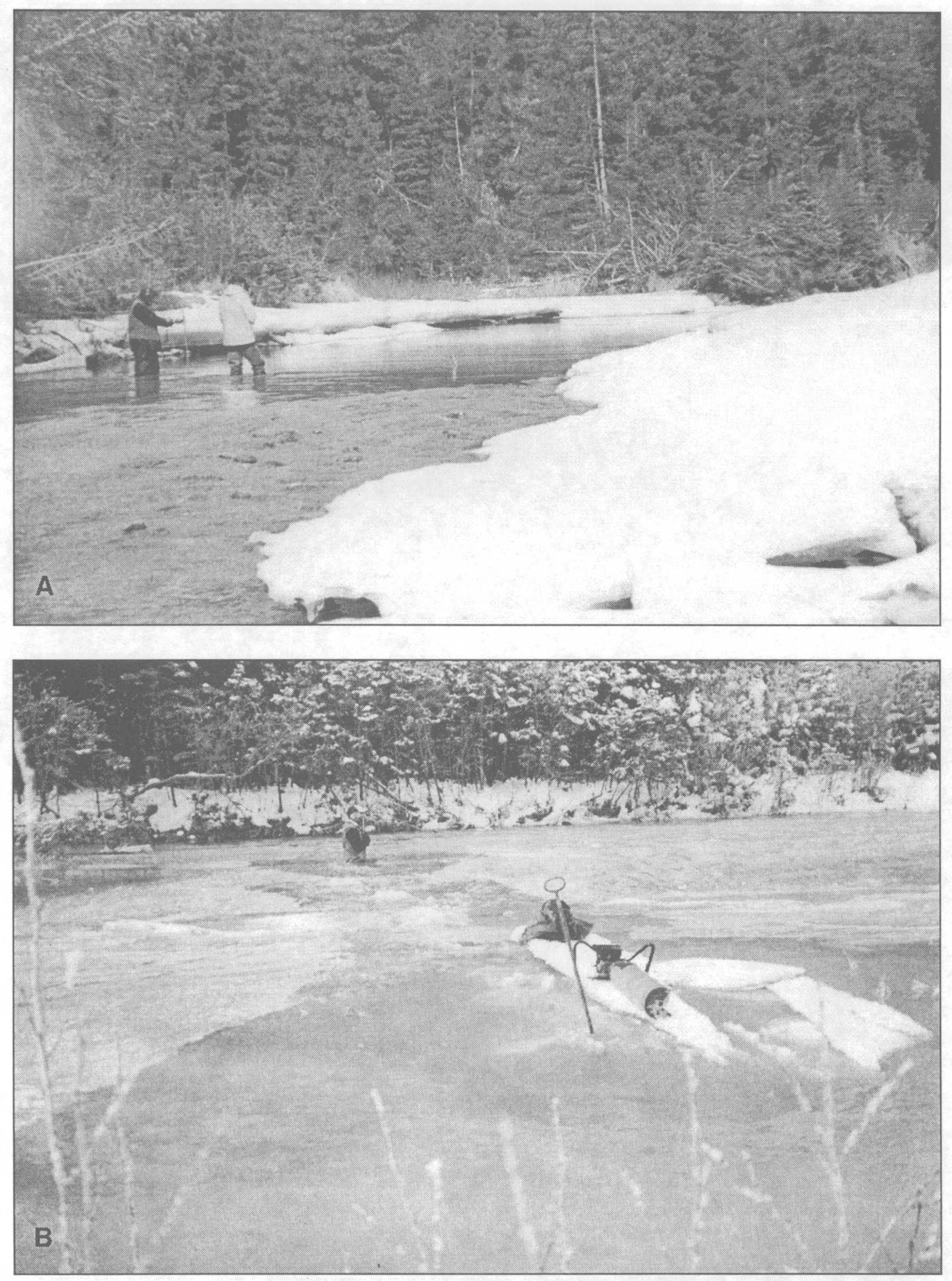

Figure 6. Bradley River at the Tidewater transect: A, looking upstream, bridged ice, no ice effect; $\mathrm{B}$, looking across transect, forming ice conditions. 

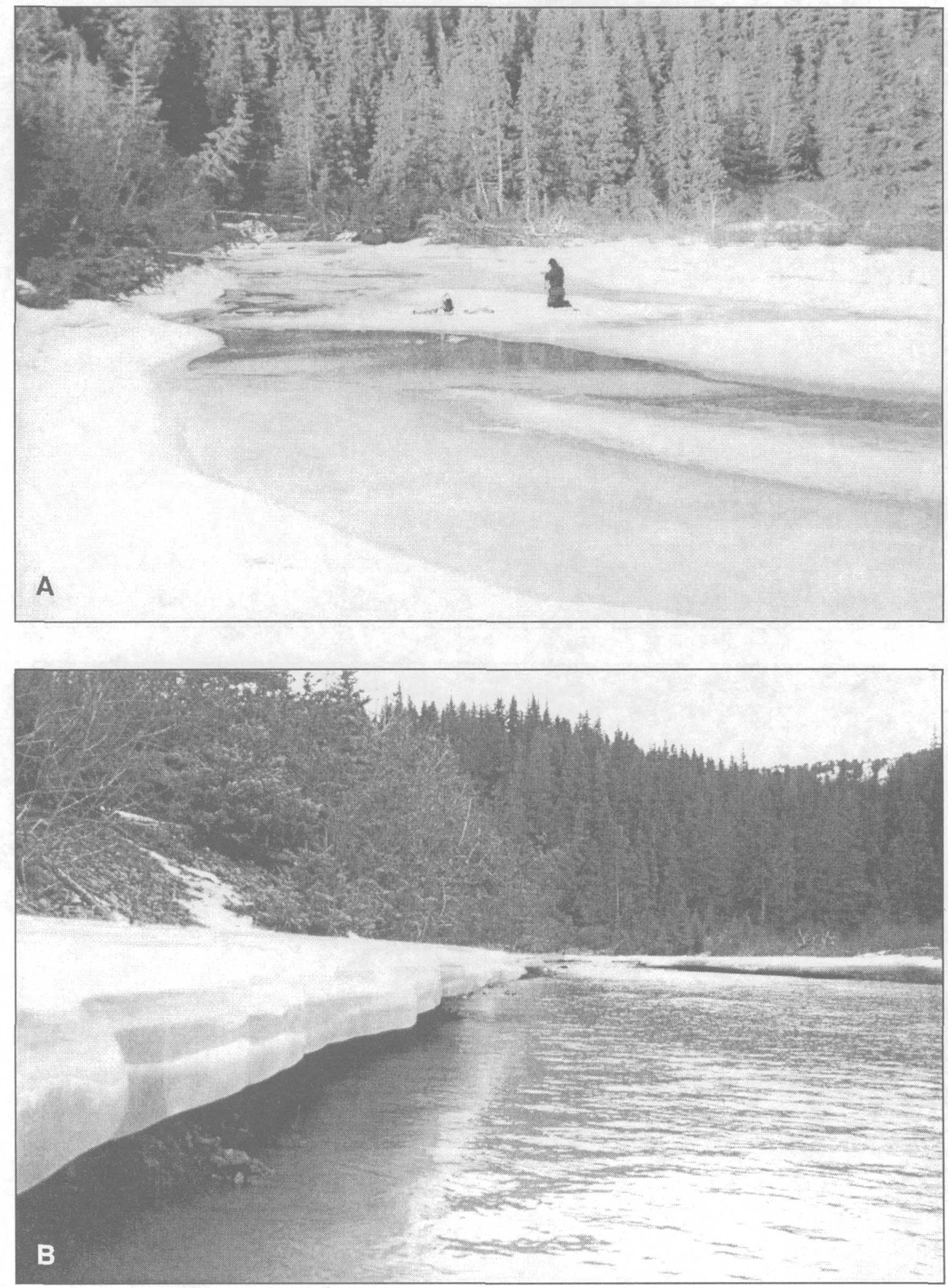

Figure 7. Bradley River at the Tree Bar reach transect, looking upstream: A, forming ice conditions; B, stable ice conditions. 


\section{Below Fish Camp Transect}

Below Fish Camp transect (fig. 3) is located approximately $150 \mathrm{ft}$ downstream from the fish camp and $500 \mathrm{ft}$ downstream from the Tree Bar Reach transect. The transect is in a riffle-to-pool transition area (fig. 4) and is characterized by moderately sloped gravel bars on both the right and left banks (fig. 8A). A small slough opening on the extreme right edge of the transect freezes solidly or goes dry between November and mid-March, but is open and contains water by late March. This slough is an important rearing habitat for chum salmon (Oncorhynchus keta) (John Morsell, Northern Ecological Services, oral commun., 1998). The channel is moderately wide. Substrate consists mostly of gravel with some cobbles. The median diameter of the substrate is $0.07 \mathrm{ft}$. This transect is affected by high tides approximately 12 to 17 days each month. Complete ice cover (fig. 8B) of the main channel is common during the winter and occurs more frequently than at the three transects described above. Ice is occasionally broken up and rafted during high tide.

\section{Upper Riffle Reach Transect}

The Upper Riffle Reach transect (fig. 3) is located approximately $850 \mathrm{ft}$ downstream from the Below Fish Camp transect, in a deep riffle (fig. 4). The river is split by a gravel bar into two channels of approximately equal width. The right channel is deeper than the left channel. A tree fell across the left channel during the fall of 1995, about $10 \mathrm{ft}$ upstream from the transect, causing sediment deposition at the transect: The right bank of the right channel is vertical and composed of tree roots and soil (fig. 9A). The left bank of the right channel and the right bank of the left channel are formed by moderately steeply sloped gravel bars that are covered sparsely with grass. The left bank of the left channel is steeply sloped and composed of tree roots and soil. The median diameter of the substrate is $0.17 \mathrm{ft}$ in the right channel and
$0.23 \mathrm{ft}$ in the left channel. During much of the winter, mud covers the substrate of approximately 25 percent of both channels, usually near the gravel bar. The mud is carried in from Kachemak Bay during high tide and is flushed out of the thalweg during tide recession and low tide. Flow circulation in Kachemak Bay is counter-clockwise, carrying fine sediment from several glacier-fed streams up toward the head of Kachemak Bay (Burbank, 1977; Daly, 1981). Fine sediment-resuspended Bradley River deposits and possibly sediment from Kachemak Bay-is carried in during high tide. Some of the sediment settles onto the streambed and may or may not be flushed out with the outgoing tide and streamflow. This transect is affected by backwater from high tide on most days during the winter. Complete ice cover (fig. 9B) is common during the winter. The right channel freezes more frequently than the left channel. Ice is occasionally broken up and rafted during high tide (fig. 9A).

\section{Lower Riffle Reach Transect}

The Lower Riffle Reach transect (fig. 3) is located $350 \mathrm{ft}$ downstream from the Upper Riffle Reach transect, in a deep riffle (fig. 4), and defines the lower boundary of the study area. The river forms two channels separated by a gravel bar. The right channel is narrower and deeper than the left channel. The right bank of the right channel is vertical or undercut, is composed of tree roots and soil, and is continuously being eroded by rapidly flowing water on top of ice during incoming tides in the winter. The left bank of the right channel and the right bank of the left channel are formed by moderately steeply sloped gravel bars that are covered sparsely with grass. The left bank of the left channel is steeply sloped and is composed of tree roots and soil. The median diameter of the substrate is $0.10 \mathrm{ft}$ in the right channel and 0.13 $\mathrm{ft}$ in the left channel. During much of the winter, mud covers approximately 25 percent of the substrate in both channels, usually near the 

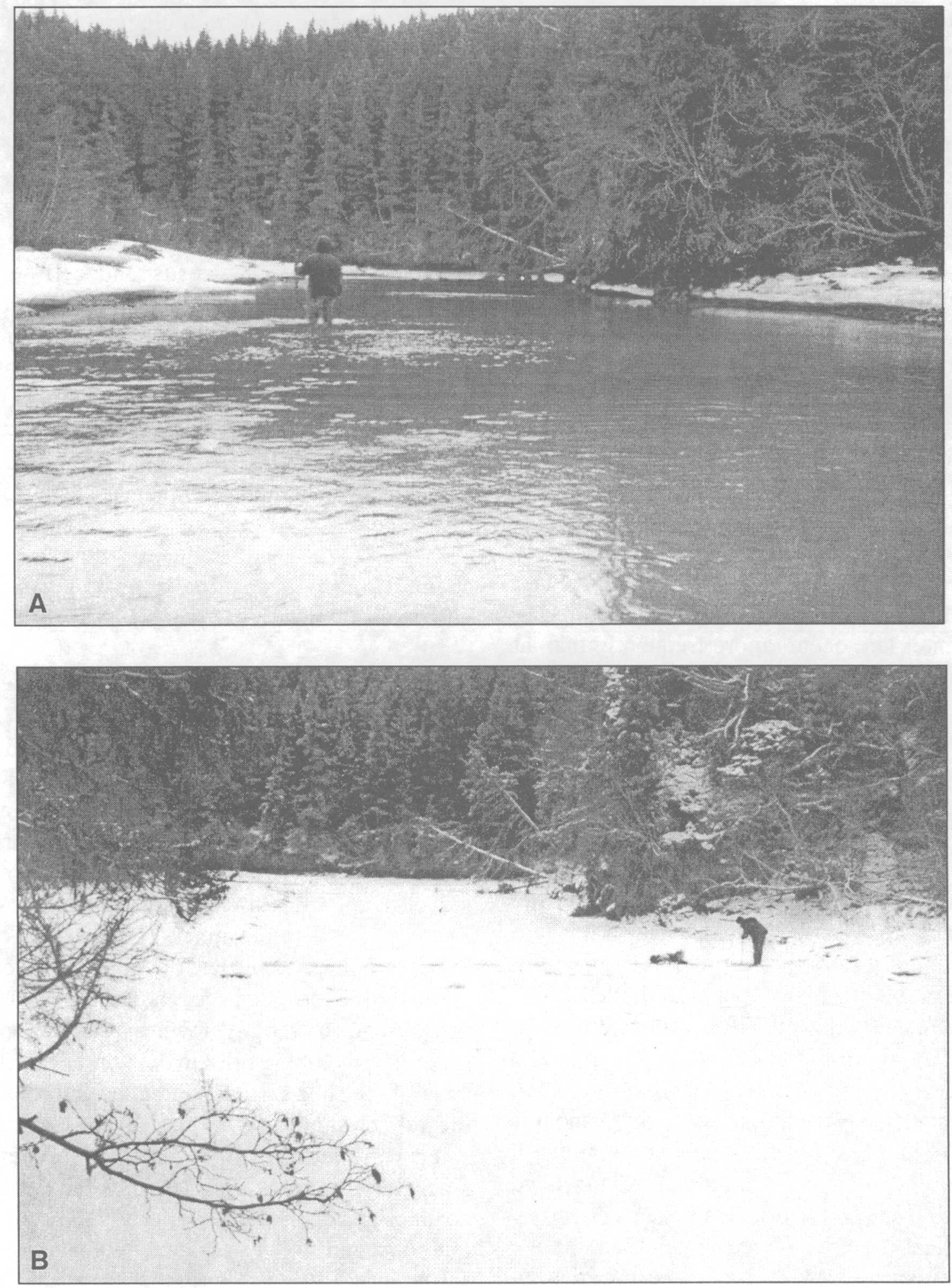

Figure 8. Bradley River at the below Fish Camp transect, looking upstream: A, no ice effect; $B$, stable ice conditions. 

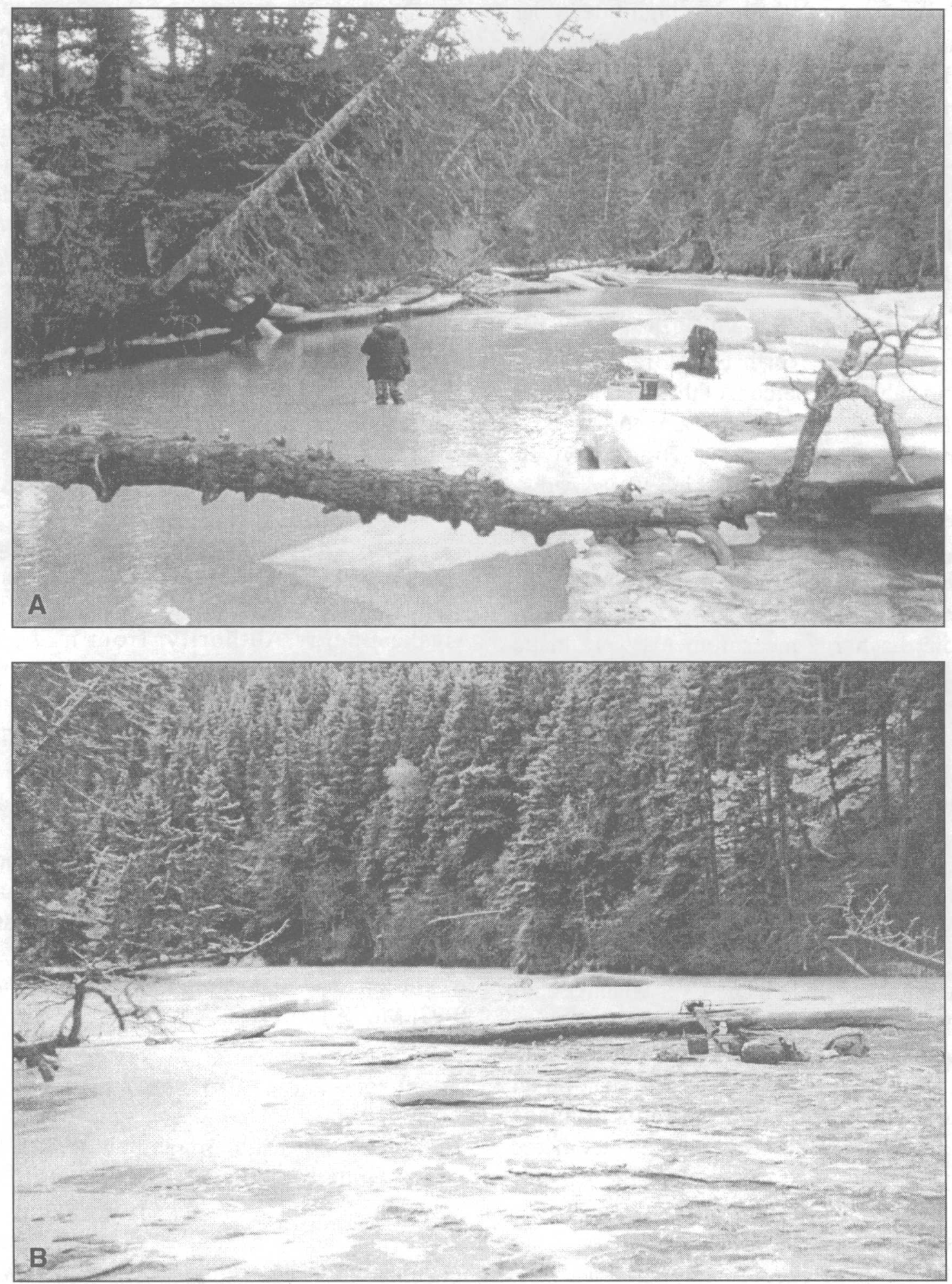

Figure 9. Bradley River at the Upper Riffle Reach transect, looking upstream: A, no ice effect (note ice blocks deposited when tide receded); B, forming ice conditions. 
gravel bar, but was observed to cover 100 percent of the transect on April 17, 1997, immediately following a relatively low high-tide cycle. This transect is affected by backwater from the daily high tide (fig. 10A) during the winter. Complete ice cover (fig. 10A and 10B) is common during the winter and is occasionally broken up and rafted during high tides (fig. 10C).

\section{Middle Fork Bradley River Below North Fork Bradley River}

The Middle Fork Bradley River below the diversion and the North Fork Bradley River constitute about 26 percent of the Bradley River basin and provide the major source of non-glacier melt water to the lower Bradley River. Water remains clear even at high flows. A discharge measuring section was established for the Middle Fork Bradley River below North Fork Bradley River (fig. 1) to help determine inflow contributions to the lower Bradley River. Periodic discharge measurements were made between March 1993 and April 1995. A continuous-recording stream-gaging station (station No. 15239060) was installed in July 1996 to provide a complete record of winter flow contributions to the lower Bradley River. The gaging station is located $0.2 \mathrm{mi}$ below the mouth of the North Fork Bradley River and $100 \mathrm{ft}$ above the confluence with the main stem of the Bradley River. The Middle Fork Bradley River below North Fork Bradley River flows through a deep narrow canyon. The river channel consists of deep pools and small waterfalls. Riverbanks consist of bedrock and the channel bottom is made up of medium gravels and small boulders. No fish are found in this drainage because obstructions downstream from the confluence with the main stem of the Bradley River prevent fish from moving upstream. Ice forms in the river in early November and remains intermittently through mid-April.

\section{METHODS AND MATERIALS}

Spawning locations and salmon populations were measured before and during this study. Hydrologic and water-quality data were collected under a variety of ice conditionsincluding many stages of active ice formation, stable ice conditions, and eroding ice conditions - throughout the winter months. In addition, a one-time rapid reduction of flow released at the fish-water bypass was performed to study the effects of a rapid decrease in flow on surface- and intragravel-water hydrologic and water-quality characteristics in the lower Bradley River.

\section{Observation of Spawning Area Locations and Estimated Escapement}

Active spawning areas were located and monitored by Northern Ecological Services of Anchorage, Alaska, under contract to the Alaska Energy Authority, from mid-July through early September 1993-98. Trap nets were used as the primary sampling technique. Each net was checked every 4 hours during normal operations. Caught fish were tagged by species using sequentially numbered Floy spaghetti tags, and sex and spawning condition were recorded (Morsell, 1996). Salmon population was measured and escapement (the number of fish that survive and spawn) estimated and compared with pre-project data (Morsell and others, 1993; Morsell, 1994, 1996, and 1997; Morsell and Howard, 1995).

\section{Measurements of Surface Water}

Measurements of streamflow were made using standard methods (Rantz and others, 1982). Photographs were taken at each transect to document ice conditions at the time streamflow measurements were made. Transects were tied to a common vertical datum for determination of water-surface elevation (Rickman, 1995). Gravel-bar slopes were measured at 

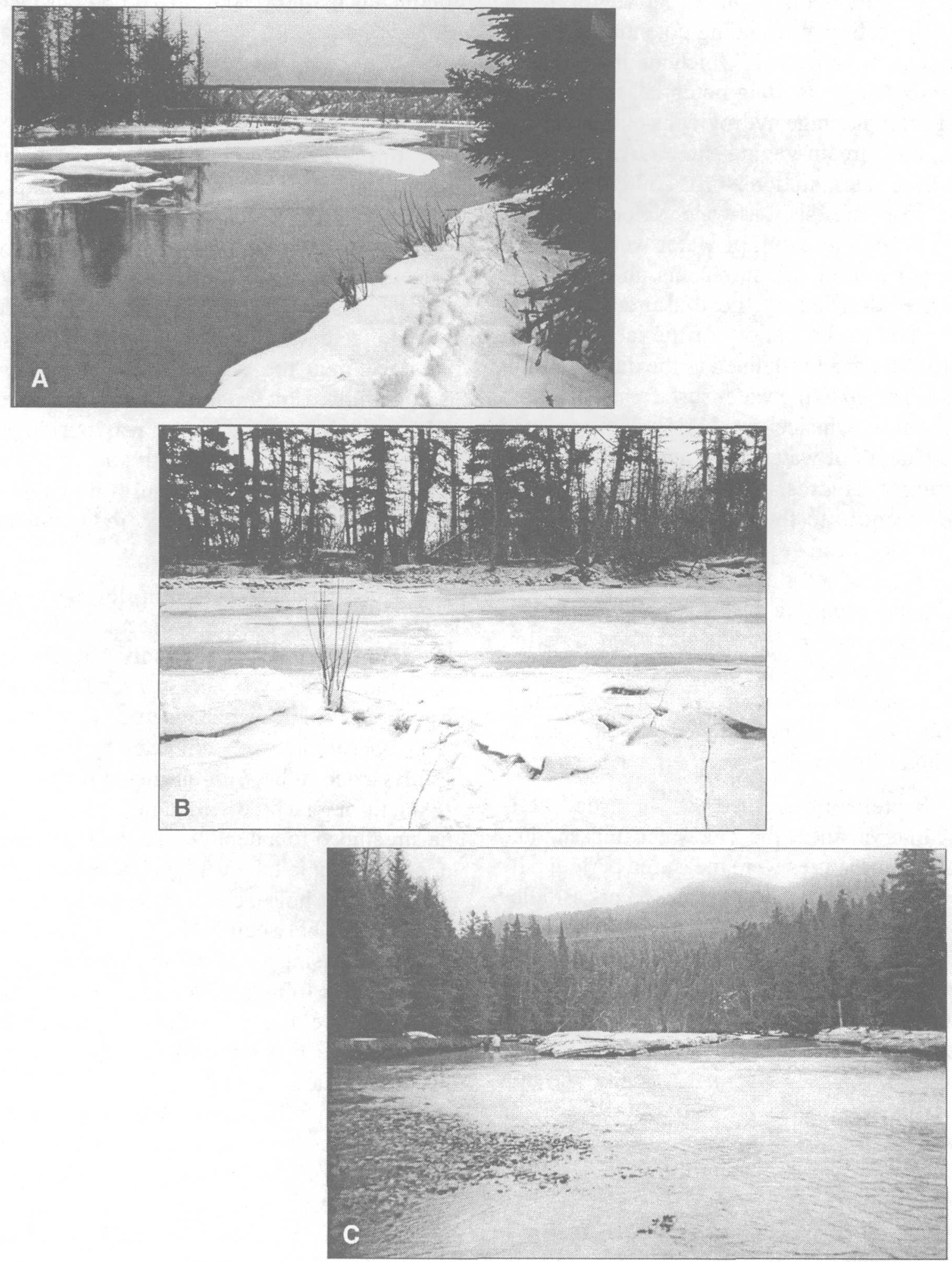

Figure 10. Bradley River at the Lower Riffle Reach transect: A, looking downstream from the right bank, complete ice cover hidden beneath water from high tide; $\mathrm{B}$, looking across transect, forming ice conditions; C, looking upstream, no ice effect (note ice blocks deposited when the tide receded). 
each transect using standard surveying techniques to estimate stranding potential. Rates of change of stream stage, which are important to understanding stranding potential, were calculated from the stage hydrographs obtained from the USGS stream-gaging station Bradley River near Tidewater (station No. 15239070). Hydrologic properties such as water velocity, hydrostatic head, and depth of water were obtained from streamflow measurements. In this report, depth is defined as the distance from the streambed to the bottom of the ice shelf, and hydrostatic head is defined as the distance from the streambed to the water surface, measured in holes cut into the ice (fig. 11). Hydrostatic head equals depth of water when ice cover is absent or bridged. Hydrostatic head is always greater than or equal to the water depth under ice. Hydrostatic head greater than water depth indicates pressurized flow. Wetted perimeter was calculated using the Slope- $\underline{\text { Area }}$ Computation (SAC) program (Fulford, 1994). Wetted perimeter, as used in this report, refers to the length of the interface of the water/streambed boundary, and does not include the ice/water boundary or portions of the streambed that are frozen.

Water temperature was recorded at 1hour intervals near the Tidewater transect, and water temperatures were measured periodically at all transects and at the Middle Fork Bradley River below North Fork Bradley River, using standard methods (Stevens and others, 1975). Specific conductance was measured according to methods described by Hem (1985) at all six transects to gain insight into ground-water contributions (Riggs, 1972, p. 12; Miller and others, 1988) and possible salt-water intrusion from high tides. Dissolved-oxygen concentration was determined using the modified Winkler method (American Public Health Association and others, 1989, p. 4-152). Barometric pressure was also measured concurrently to calculate the percent oxygen saturation. Duplicate measurements of water temperature, dissolved oxygen, and specific conductance were taken on 16 percent of the measurements.

\section{Measurements of Intragravel Water}

Intragravel water is defined as the fluid occupying the porous interior of the streambed. For this study, it was the interstitial water collected from 8 to 12 in. below the streambed surface-the depth of buried eggs-for physical and chemical analysis. Water-temperature data were collected at 1-hour intervals throughout the study near the Tree Bar Reach transect, using standard methods (Stevens and others, 1975). A temperature probe was buried to a depth of 12 in., but this depth varied slightly during the study period because of scour and fill of the streambed caused by redd construction.

Dissolved-oxygen samples were collected using special equipment and procedures that differ from those commonly used for fisheries studies. This was necessary to collect representative samples when ice was present in the river. The samples were collected by inserting a stainless-steel tube with an inside diameter of $3 / 16$ in. through a hole drilled in the ice and into the streambed to a depth of 12 in. The lower 4 in. of the sample tube was perforated with $1 / 16^{-}$ inch diameter holes, enabling water samples to be collected between 8 and 12 in. below the streambed. Using a peristaltic pump with Masterflex C-flex tubing (chosen for its durability in cold temperatures and low oxygen permeability), water was pumped at a rate of 8 to 10 $\mathrm{mL}$ per minute into a $60-\mathrm{mL}$ biochemical oxygen demand (BOD) bottle. The slow pumping rate was necessary to prevent surface-water intrusion (Hoffman, 1986, p. 446). A total of three sample volumes were pumped through the bottles, and the samples were fixed and analyzed using the azide modification of the Winkler method. The pump and BOD bottle were kept at approximately $2{ }^{\circ} \mathrm{C}$ using water bottles inside a small cooler to keep sample water from 

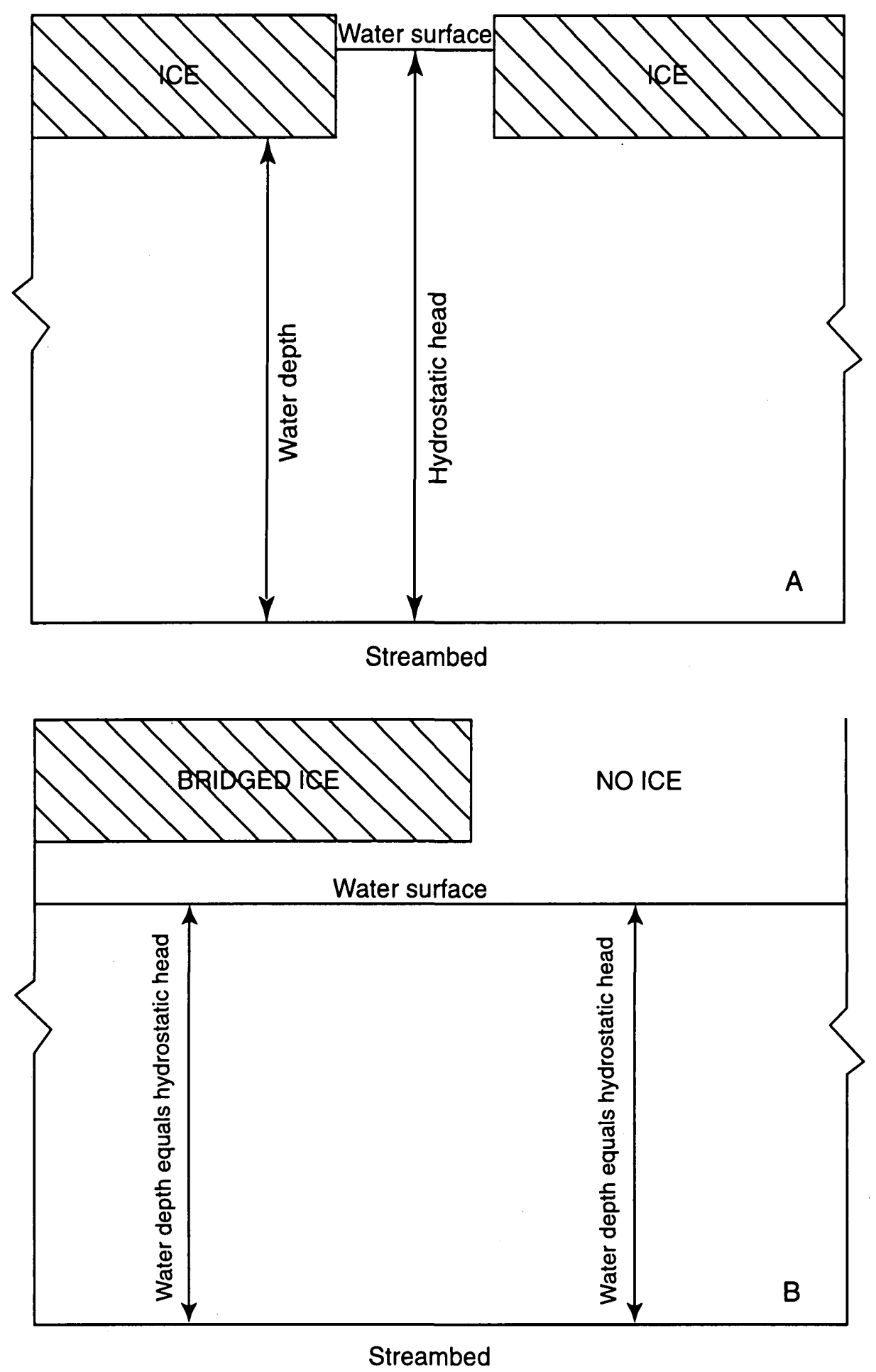

Figure 11. Definitions of water depth and hydrostatic head as used in this report: A) Ice supported by water column, and B) Bridged ice or no ice. 
freezing whenever the air temperature was below $0{ }^{\circ} \mathrm{C}$. Silt content in dissolved-oxygen samples, depth of surface water, and surfacewater velocity at the sample sites were recorded. Water temperature was measured at the Tree Bar Reach transect using the intragravel temperature probe and for all other samples by measuring water temperature in the BOD bottles. The percent dissolved-oxygen interchange between surface and intragravel water was calculated (Woods, 1980).

\section{Observations and Measurement of Fine-Sediment Deposition}

Embeddedness is generically defined as the amount of fine sediment that is deposited in the interstices between larger streambed substrate particles. Measuring embeddedness is a common approach to quantifying sediment deposition on spawning beds (Chapman and McLeod, 1987). In this study, however, it could not be accurately measured because of high turbidity caused by release of glacial-melt water at the fish-water bypass (fig. 1). A view tube was constructed from 18-inch diameter PCV pipe using a clear lexan plate with a 1 -inch grid pattern for viewing. The entire study reach was observed systematically in early April 1997 and in October 1997 in an attempt to identify areas of fine-sediment deposition. Detailed observations of the streambed were made at many locations along the entire reach on June 4, 1997 when the water in lower Bradley River was clear. However, visual methods of embeddedness have been found to be unreliable when the fines tend to be silt and clay (as opposed to sand size) (J.W. Burns and R.E. Edwards, Payette National Forest, written commun., 1985), which is the case in the lower Bradley River.

Suspended-sediment samples were collected in January 1998 with a depth integrating sampler, using a five-point equal discharge increment (EDI) method (Guy and Norman, 1970). Suspended-sediment particle-size analy- sis was done using wet sieve and sedigraph methods (Guy, 1969). Fine-sediment deposition potential was estimated using particle fall rate data and shear velocity calculations (Alonso and Mendoza, 1992).

\section{RESULTS AND DISCUSSION}

\section{Escapement Estimates and Spawning Locations}

Pink salmon escapement data are summarized in figure 12. Data for periods outside the scope of this study are included to illustrate the differences between even-year and odd-year pink salmon stocks, and the effects of regulated flow. Escapement numbers in even years are much lower than those in odd years as a result of severe flooding during the fall of 1986 , which caused significant streambed erosion and resulted in the destruction of many of the redds. Following the even-year trend, escapement during 1996 was low, possibly compounded by poor salt-water survival (Morsell, 1996). Other factors-including prolonged cold air temperatures during the 1994-95 winter- reduced wild pink salmon stocks. Overall escapement has been higher during the period of regulated flow (fig. 12).

Spawning locations, shown in figure 3, have not changed significantly with regulated flow. Most pink salmon spawning occurs between the Tidewater and Tree Bar Reach transects. Spawning activity is intermittent at Lower Riffle Reach (Morsell, 1993, 1996).

\section{Ice Formation and Streamflow}

Ice formation in the lower Bradley River, measured at the stream-gaging station Bradley River near Tidewater (station No. 15239070), was intermittent during the study period (table 1, fig. 13). 


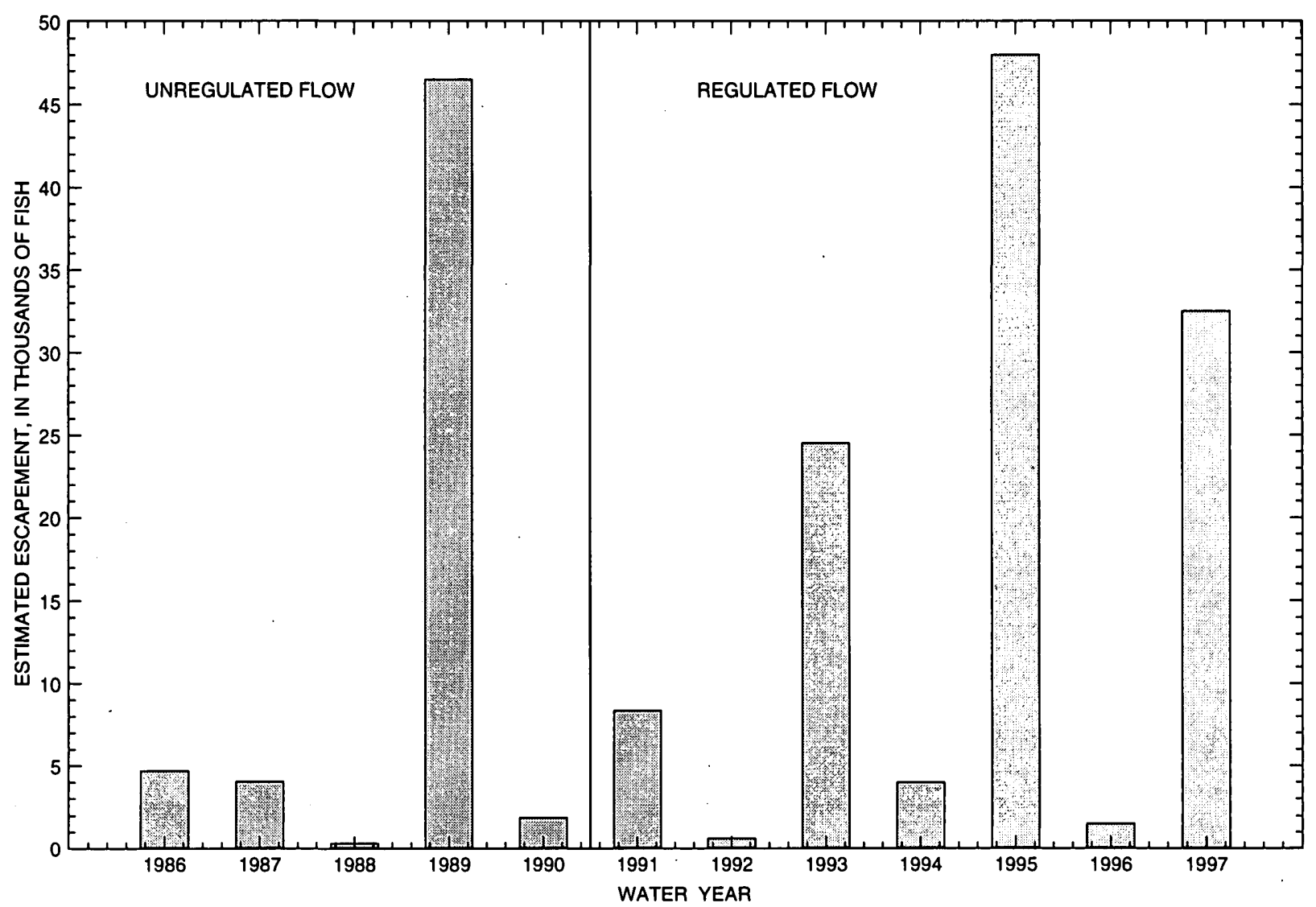

Figure 12. Estimated escapement for pink salmon, 1986 to 1997. (Data provided by John Morsell, Northern Ecological Services.)

Table 1. Summary of ice formation at the stream-gaging station Bradley River near Tidewater

\begin{tabular}{lcccc}
\hline \multicolumn{1}{c}{ Period } & $\begin{array}{c}\text { Total number of } \\
\text { days of ice } \\
\text { formation }\end{array}$ & $\begin{array}{c}\text { Percent of } \\
\text { period that was } \\
\text { ice affected }\end{array}$ & $\begin{array}{c}\text { Range of } \\
\text { consecutive days } \\
\text { of ice formation }\end{array}$ & Reference \\
\hline March 1 to April 30, 1993 & 12 & 19 & 1 to 5 & Linn and others, 1994 \\
Nov. 1, 1993 to April 30, 1994 & 88 & 49 & 1 to 43 & Bigelow and others, 1995 \\
Nov. 1, 1994 to April 30, 1995 & 129 & 71 & 1 to 75 & Schellekens and others, 1996 \\
Nov. 1, 1995 to April 30, 1996 & 97 & 53 & 1 to 54 & Linn and others, 1997 \\
Nov. 1, 1996 to April 30, 1997 & 103 & 57 & 4 to 69 & Benson and others, 1998 \\
Nov. 1, 1997 to April 30, 1998 & 91 & 50 & & Rickman, 1998 \\
\hline
\end{tabular}



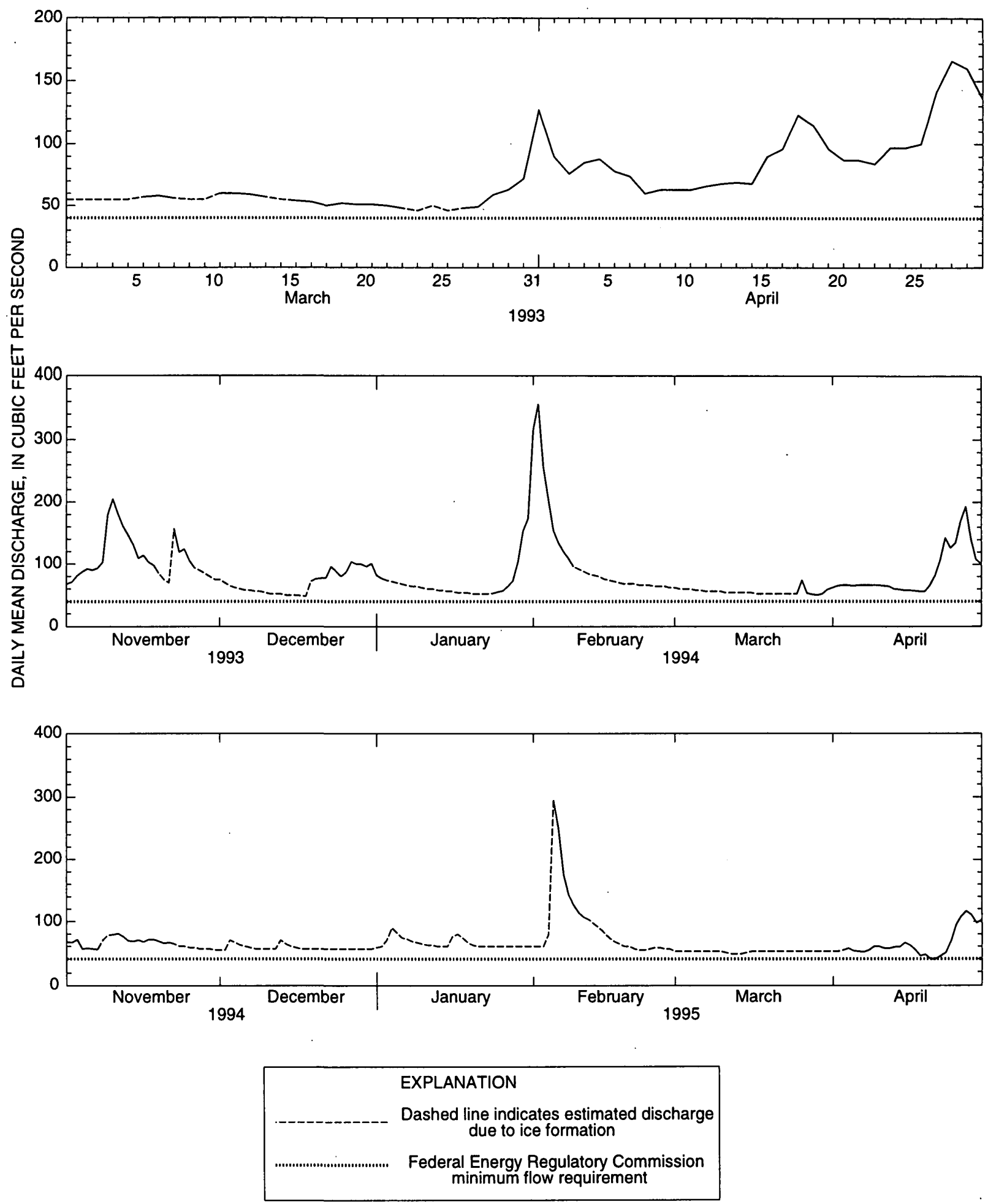

Figure 13. Daily mean discharges for Bradley River near Tidewater (station number 15239070). 

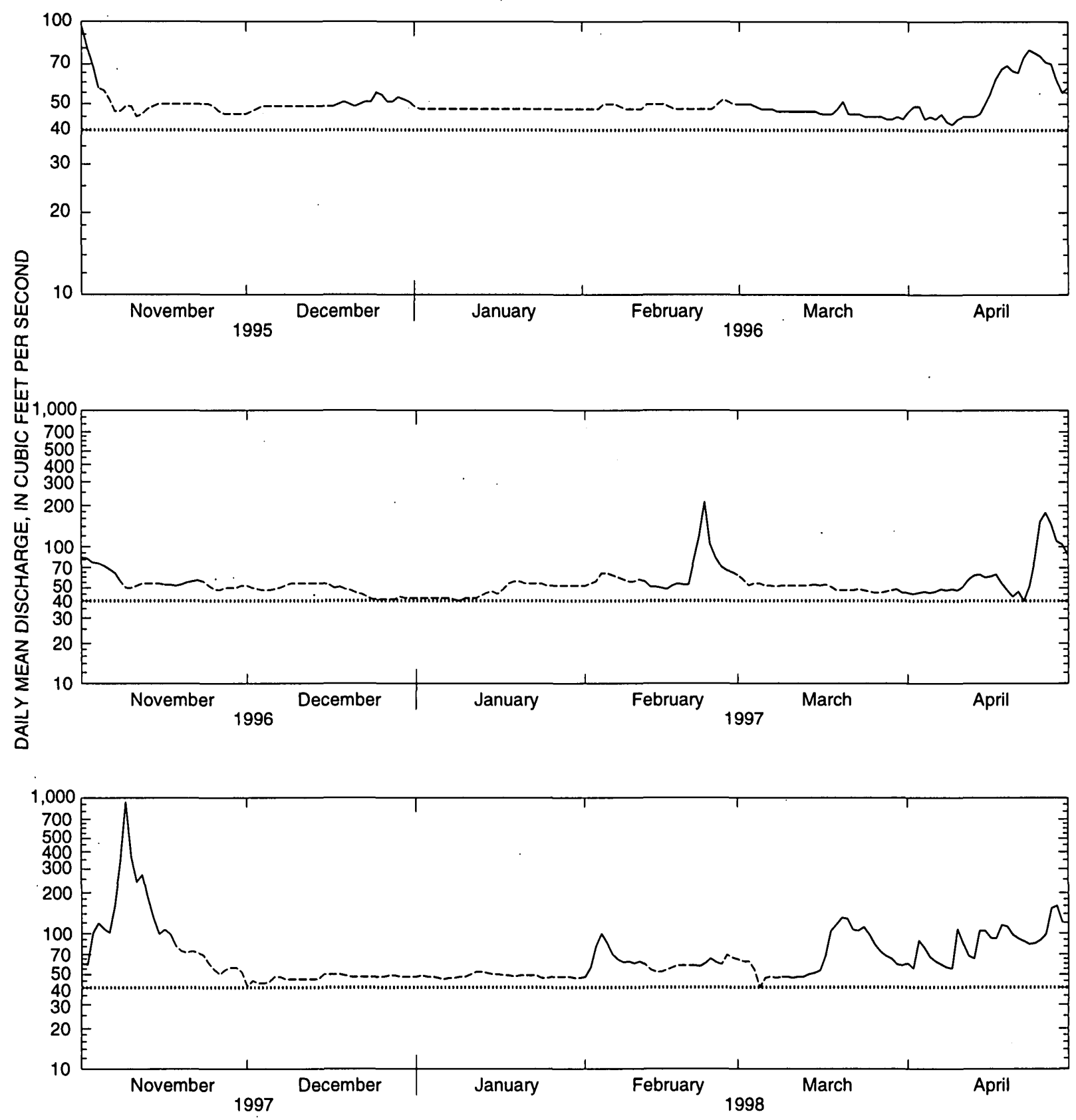

EXPLANATION

Dashed line indicates estimated discharge due to ice formation

......................... Federal Energy Regulatory Commission minimum flow requirement

Figure 13. Continued. 
The period of March 1 to April 30, 1993, was mostly ice free, with a few days of shoreice formation. Ice formation for the periods November 1, 1993, to April 30, 1994, and 1996-98 was usually shore ice, with short periods of complete ice cover. Ice formed in the lower Bradley River 71 percent of the time between November 1, 1994, and April 30, 1995. The extended ice effect may have adversely impacted incubation habitat, as evidenced by the low escapement during 1996 (fig. 12). The river was completely ice covered during much of this period. The longest continuous periods of ice effect occur from January to March. Periods of single-day ice effect can occur any time from November through April.

Detailed discussions of river ice formation mechanisms and types of river ice are available elsewhere (Rantz and others, 1982, p. 360-364; Ashton, 1986, p. 261-371). For this report, river icing has been divided into three phases: forming, stable, and eroding. Understanding these phases and their effects on the hydrologic and water-quality properties is important for determining the effects of the existing winter flow conditions and lesser flows on salmon incubation habitat. The characteristics and causes of forming, stable, and eroding ice are discussed below and the effects of ice conditions on hydrologic and water-quality properties are discussed is sections found later in this report.

Forming: Throughout this study, ice was observed to form in the lower Bradley River by coalescing of frazil ice, anchor ice formation, and shore-fast ice formation. Ice in the form of fine elongated needles, thin sheets, or cubical crystals, also known as "frazil ice," is common in turbulent streams. Anchor ice forms when super-cooled liquid water attaches or nucleates to form ice on the streambed (Ashton, 1986, p. 282). Shore-fast ice was observed to form and then grow and extend across the river channel leaving a single narrow open lead. Eventually this lead may freeze over completely. Backwa- ter conditions were greatest during ice formation. Hydrostatic head was usually much greater than water depth. Occasionally, hydrostatic head was higher than the top of the ice sheet, with water flowing out of the holes drilled in the ice (fig. 14). Evidence of forming

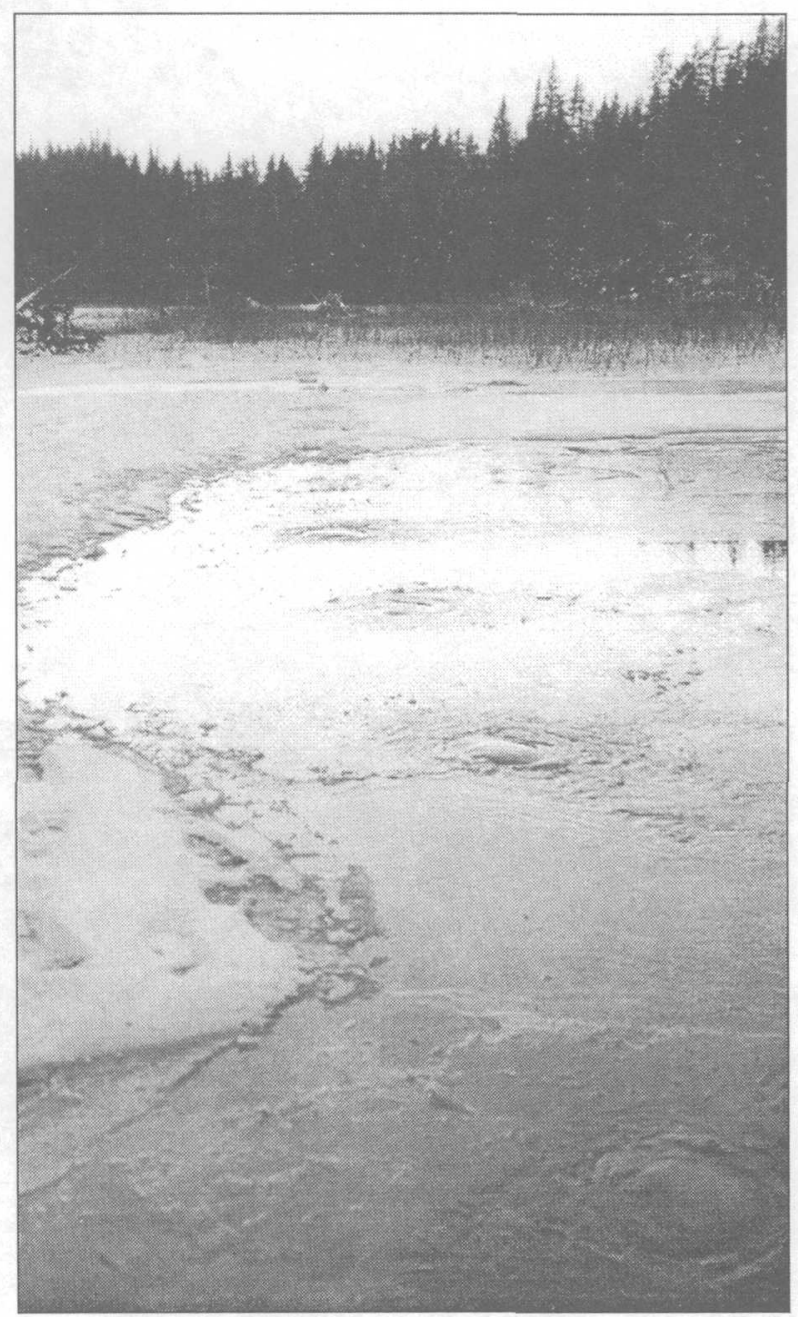

Figure 14. Water flowing out of holes drilled through the ice, indicating pressurized flow, during a period of forming ice.

ice conditions, which can be observed using real-time gage-height and air temperature data, is a rapid increase in gage height (non-tide influenced), coupled with cold air temperatures, usually less than $-5^{\circ} \mathrm{C}$.

Stable: Ice conditions usually reached a point of equilibrium where ice was neither 
forming nor eroding at a noticeable rate. For this report, this condition is referred to as stable. Ice can be either thick or thin, and have either complete or shore-fast ice cover. Anchor ice was never observed to be present during stable conditions. Backwater effects were highly variable, but usually less than those observed during periods of ice formation.

Eroding: Several factors can contribute to ice erosion. Warm water $\left(2\right.$ to $\left.4{ }^{\circ} \mathrm{C}\right)$ released from Bradley Lake in November and early December can weaken and erode ice even during periods of cold air temperatures. Water released from the lake after mid-December is no longer warm enough to cause ice erosion in the lower Bradley River. Periods of warm air temperature also weaken and erode ice, as do high tides. After mid-March, direct sunshine can erode the ice even though ambient temperatures (measured in the shade) are below $0{ }^{\circ} \mathrm{C}$. These factors can act together or independently. Eroded ice is often broken up during high-tide cycles. Some of the ice is rafted out into Kachemak Bay with the outgoing tide, and some remains dispersed within the study area. Some shore-fast ice remains and is commonly "bridged" above the water surface, causing no backwater effect.

Discharge, measured at the time hydrologic and water-quality data were being collected in the lower Bradley River, ranged from 42.7 to $73.0 \mathrm{ft}^{3} / \mathrm{s}$ ( 7 to 83 percent higher than the target flow of $40 \mathrm{ft}^{3} / \mathrm{s}$ ) between March 1993 and November through April 1994-95. The average discharge during this period was 57 $\mathrm{ft}^{3} / \mathrm{s}$, which is significantly higher than the target flow of $40 \mathrm{ft}^{3} / \mathrm{s}$. Discharge in the lower Bradley River ranged from 33.3 to $72.8 \mathrm{ft}^{3} / \mathrm{s}$ between November 1995 and April 1998. The average discharge during this period was 49 $\mathrm{ft}^{3} / \mathrm{s}$. Comparison of discharge measurements made at the six transects indicates no net exchange between ground water and stream water from the Bear Island transect to the Lower Riffle Reach transect.
On March 4, 1998, discharge from the fish-water bypass (fig. 1) was instantaneously reduced from 41 to $22 \mathrm{ft}^{3} / \mathrm{s}$ to study the effects of a rapid drop in flow in the lower Bradley River. Discharge in the lower Bradley River dropped from 62 to $43 \mathrm{ft}^{3} / \mathrm{s}$ during a 3.5-hour time period. Ice cover was observed to sag in the center of the stream channel and become bridged along the streambanks. Discharge in the lower river held steady until early on March 5 , when discharge decreased to a measured low of $33.3 \mathrm{ft}^{3} / \mathrm{s}$ because of an ice blockage upstream from the study reach.

\section{Hydrologic Properties}

Selected hydrologic properties of the transects in the lower Bradley River have been reported elsewhere (Rickman, 1995, 1996, and 1998) and are summarized below.

\section{Surface-Water Hydrostatic Head and Water Depth}

Adequate hydrostatic pressure is necessary to force the movement of intragravel water, which, in turn, supplies dissolved oxygen to the eggs and alevins, and removes metabolic waste (Reiser and White, 1981). Previous studies (Reiser and White, 1981; Woodward-Clyde, 1983; and Morsell, 1994) use surface-water depth - a measure of hydrostatic head-as an indicator of hydrostatic pressure. Reported depths required for pink salmon incubation range from greater than $0.2 \mathrm{ft}$ (WoodwardClyde, 1983, p. A5) to greater than $0.5 \mathrm{ft}$ (Reiser and White, 1981; Morsell, 1994, p. 3). The Woodward-Clyde study used $0.2 \mathrm{ft}$ as the minimum allowable depth for adequate embryo development for their open-water instream flow model. However, none of the previous studies accounted for the effect of ice formation, which can increase hydrostatic head above water depth because of pressurized flow (fig. 11).

Mean depths (non-tide affected) ranged from $0.41 \mathrm{ft}$ at Bear Island transect (January 9, 
1997; discharge, $41.4 \mathrm{ft}^{3} / \mathrm{s} ; 100$ percent ice cover, stable) to $2.03 \mathrm{ft}$ at Tidewater transect (November 11, 1996; $43.4 \mathrm{ft}^{3} / \mathrm{s} ; 100$ percent ice cover, forming) and were usually smallest at the Bear Island transect and largest at the Tidewater transect. This is expected because the Bear Island transect is the widest and the Tidewater transect is the narrowest of the six transects. Within each transect, depths were greater than $0.2 \mathrm{ft}$, except within a few feet of gravel streambanks. Mean depths at all the transects during periods of eroding or no ice were slightly larger than those predicted using the open-water instream flow model between 40 and $50 \mathrm{ft}^{3} / \mathrm{s}$ (Woodward-Clyde, 1983). This may be due to differences in transect locations between the Woodward-Clyde study and this study, and (or) channel changes resulting from the floods of October and December 1986.

Mean hydrostatic heads (non-tide affected) for various ice conditions at the six study transects are shown in figures 15A-20A. Mean hydrostatic head ranged from $0.46 \mathrm{ft}$ at Bear Island transect (April 23, 1997; discharge, $40.5 \mathrm{ft}^{3} / \mathrm{s}$; no ice) to $2.72 \mathrm{ft}$ at Tidewater transect (January 11, 1996; $43.4 \mathrm{ft}^{3} / \mathrm{s} ; 100$ percent ice cover, forming). Bear Island and Tree Bar Reach transects showed the smallest overall hydrostatic depths. Within each transect, hydrostatic head was greater than $0.2 \mathrm{ft}$ near the streambanks (even though depth of water was less than $0.2 \mathrm{ft}$ ) during periods of forming and stable ice conditions. Mean hydrostatic heads for all transects during periods of forming and stable ice conditions were larger than depths of water predicted using the open-water instream flow model (Woodward-Clyde, 1983, p. B-14, B-16).

Mean hydrostatic head was generally at a minimum during periods of eroding or no ice (figs. 15A-20A). The overall lowest mean hydrostatic head measured for all six transects combined occurred on April 23, 1997 during a period of open water (no ice; discharge ranged from $40.5 \mathrm{ft}^{3} / \mathrm{s}$ at Bear Island to $49.9 \mathrm{ft}^{3} / \mathrm{s}$ at
Lower Riffle Reach). The hydrostatic head data from the six transects for the April 23, 1997 event were integrated to include the entire pink salmon incubation habitat within the study reach and show that 96 percent of the wetted stream bottom had a hydrostatic head greater than $0.2 \mathrm{ft}$.

Minimum hydrostatic head generally occurred during periods of eroding or no ice. Under these conditions, the original instream flow model is probably valid. Data from the Woodward-Clyde study indicated a 9 percent loss in incubation habitat from a minimum allowable flow of $40 \mathrm{ft}^{3} / \mathrm{s}$ to $30 \mathrm{ft}^{3} / \mathrm{s}$, based on predicted water depths (Woodward-Clyde, 1983 , p. 5). In the event of a rapidly decreasing flow, hydrostatic head would decrease, possibly to the point where ice shelves become bridged, in which case hydrostatic head would equal water depth, or the ice may collapse. In either case, at a minimum discharge of $30 \mathrm{ft}^{3} / \mathrm{s}$, hydrostatic head would be adequate for incubation habitat protection, using the criteria from the Woodward-Clyde instream flow study.

Mean depths and hydrostatic heads during periods of high tide are much larger than those observed during low tide-regardless of ice conditions-for the Below Fish Camp and Upper and Lower Riffle Reach transects. Increases in mean depths and hydrostatic head are smaller and less frequent in the Bear Island, Tidewater, and Tree Bar Reach transects (figure 4).

\section{Surface-Water Velocity}

Adequate surface-water velocity is necessary during the winter to prevent freezing of the streambed gravels and to assure adequate incubation success. Surface-water velocity has a direct relation to intragravel-water velocity, which is important for supplying dissolved oxygen to the eggs and removing metabolic wastes (Wickett, 1954, p. 945; Coble, 1961, p. 469; Vaux, 1968, p. 479; Johnson, 1980, p. 156). Minimum velocities of surface water in 

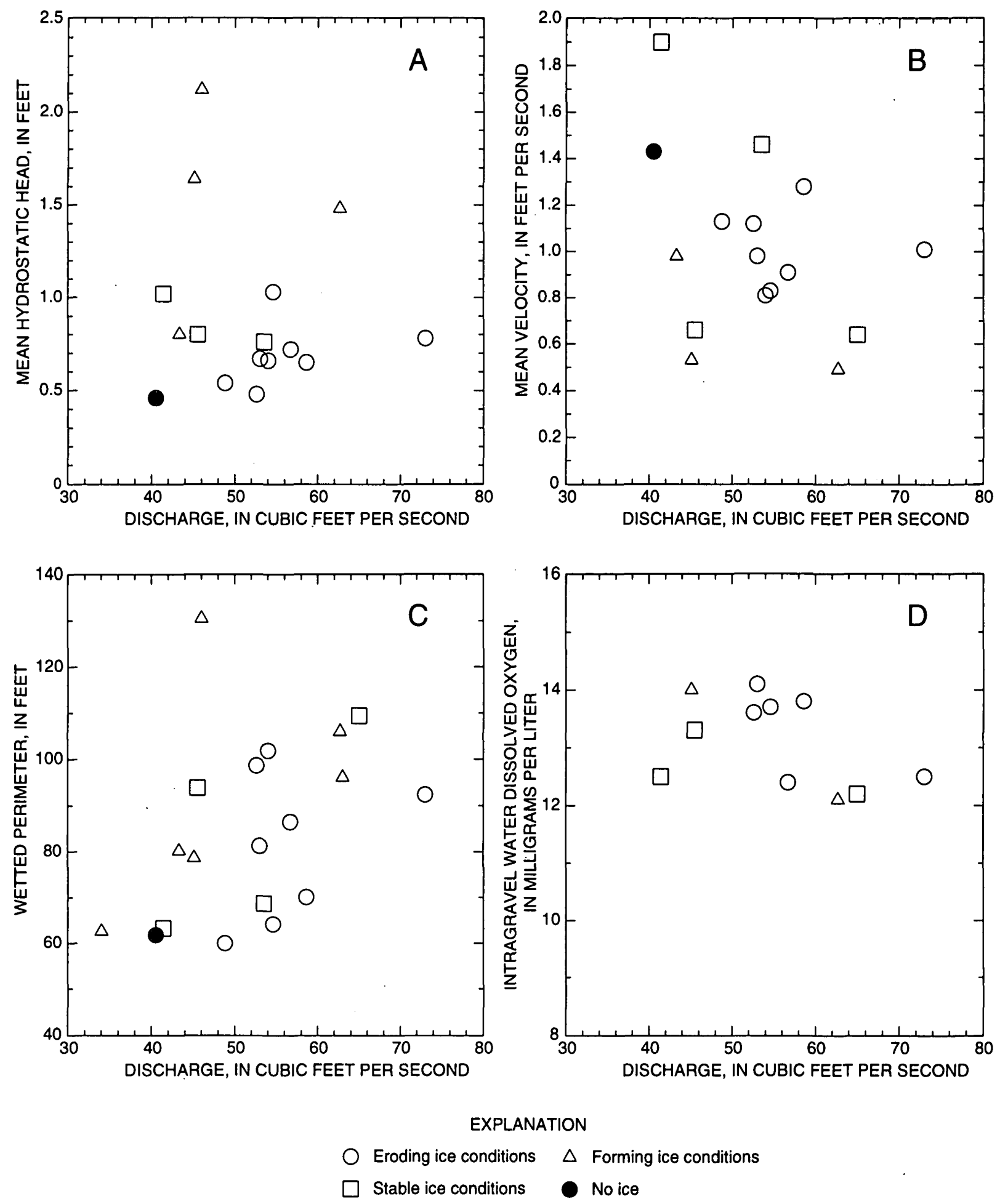

Figure 15. Selected physical properties relative to discharge, Bradley River at Bear Island transect. (See figure 3 for transect location.) 

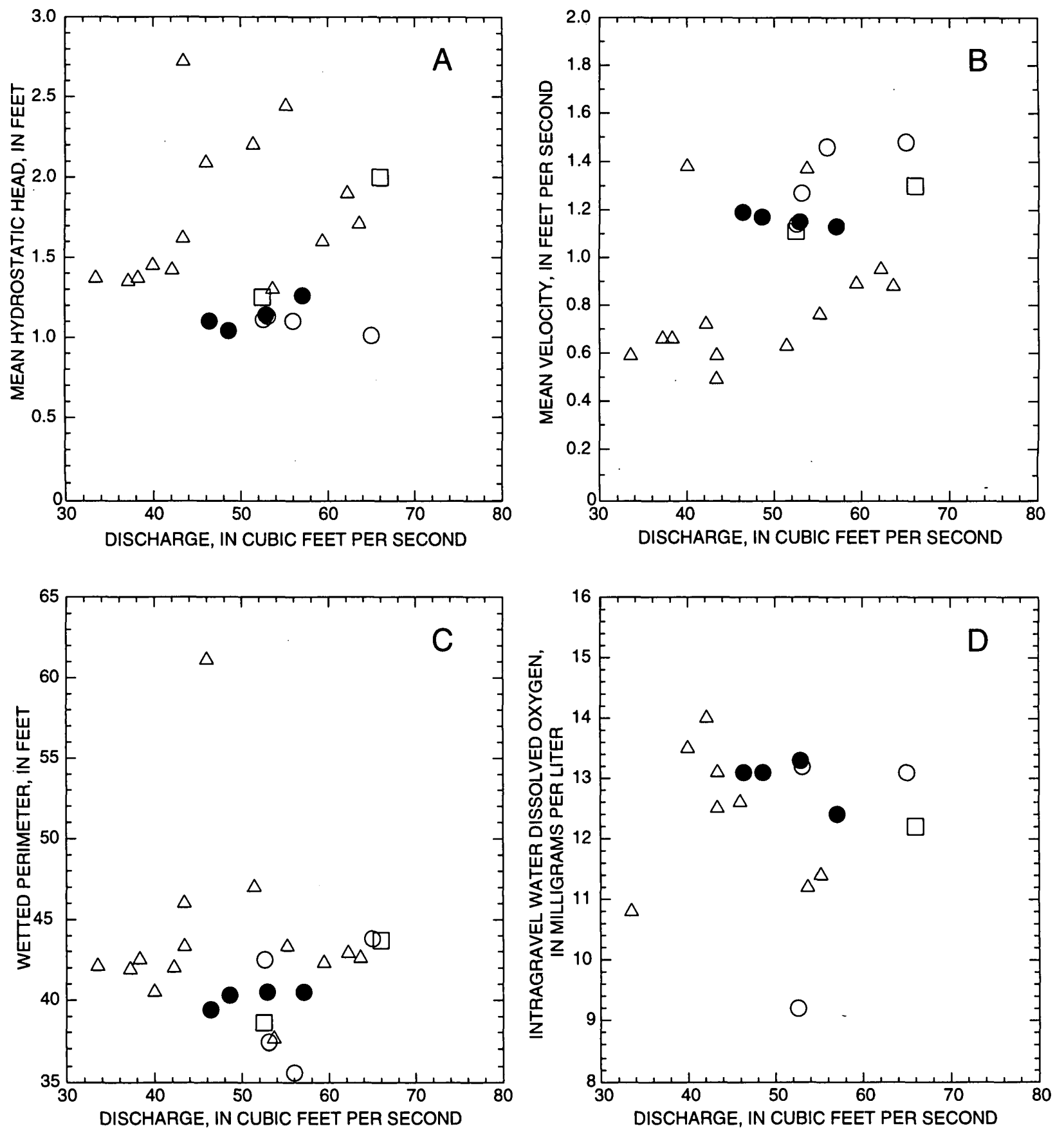

$$
\begin{aligned}
& \text { EXPLANATION } \\
& \text { Eroding ice conditions } \\
& \text { Stable ice conditions } \\
& \triangle \text { Forming ice conditions } \\
& \text { - No ice }
\end{aligned}
$$

Figure 16. Selected physical properties relative to discharge, Bradley River near Tidewater transect. (See figure 3 for transect location.) 

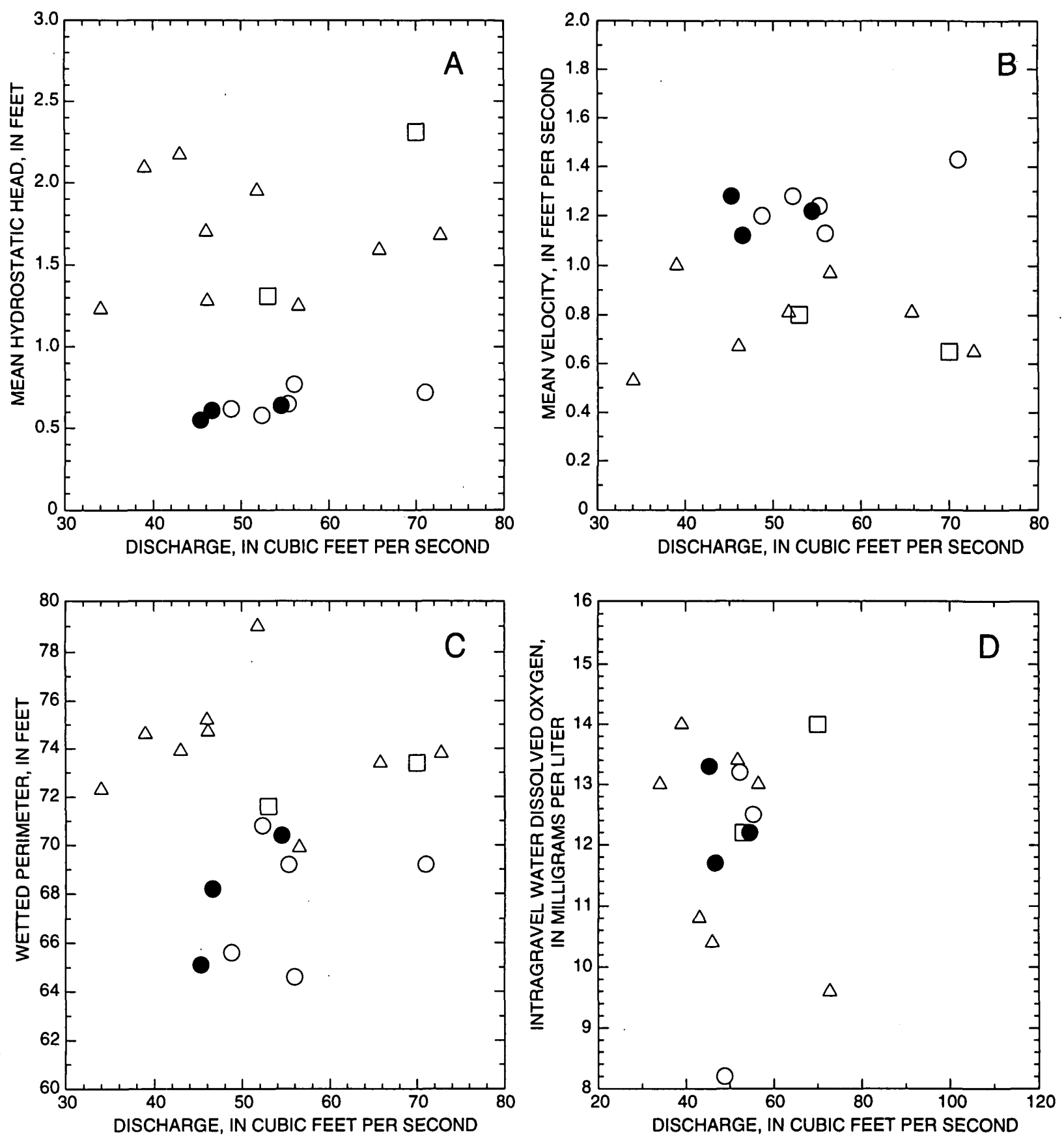

EXPLANATION

$\bigcirc$ Eroding ice conditions

Stable ice conditions at time of measurement

$\triangle$ Forming ice conditions

No ice

Figure 17. Selected physical properties relative to discharge, Bradley River at Tree Bar Reach transect. (See figure 3 for transect location.) 

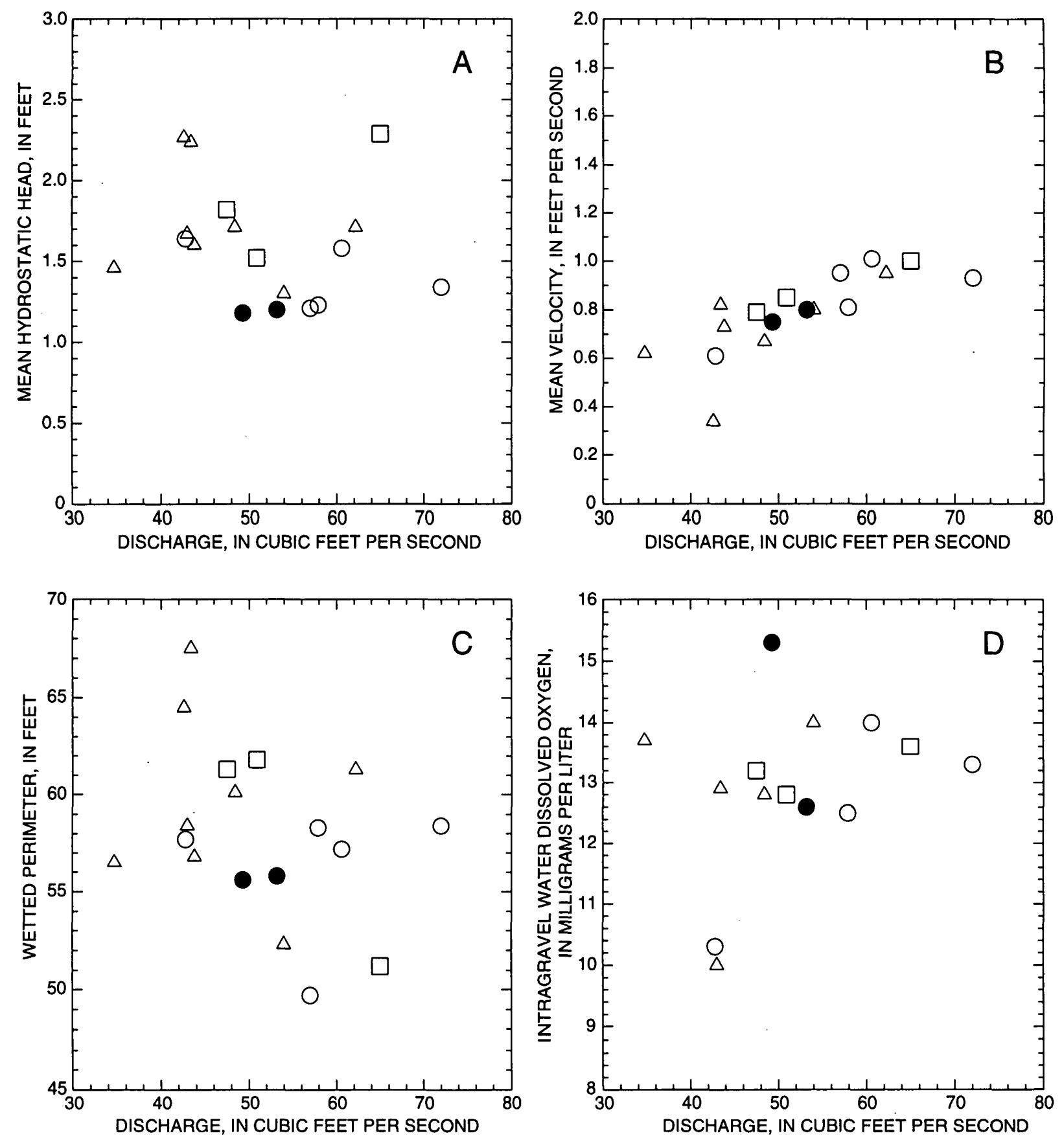

EXPLANATION

Eroding ice conditions

Stable ice conditions

$\triangle$ Forming ice conditions

- No ice

Figure 18. Selected physical properties relative to discharge, Bradley River below Fish Camp transect. (See figure 3 for transect location.) 

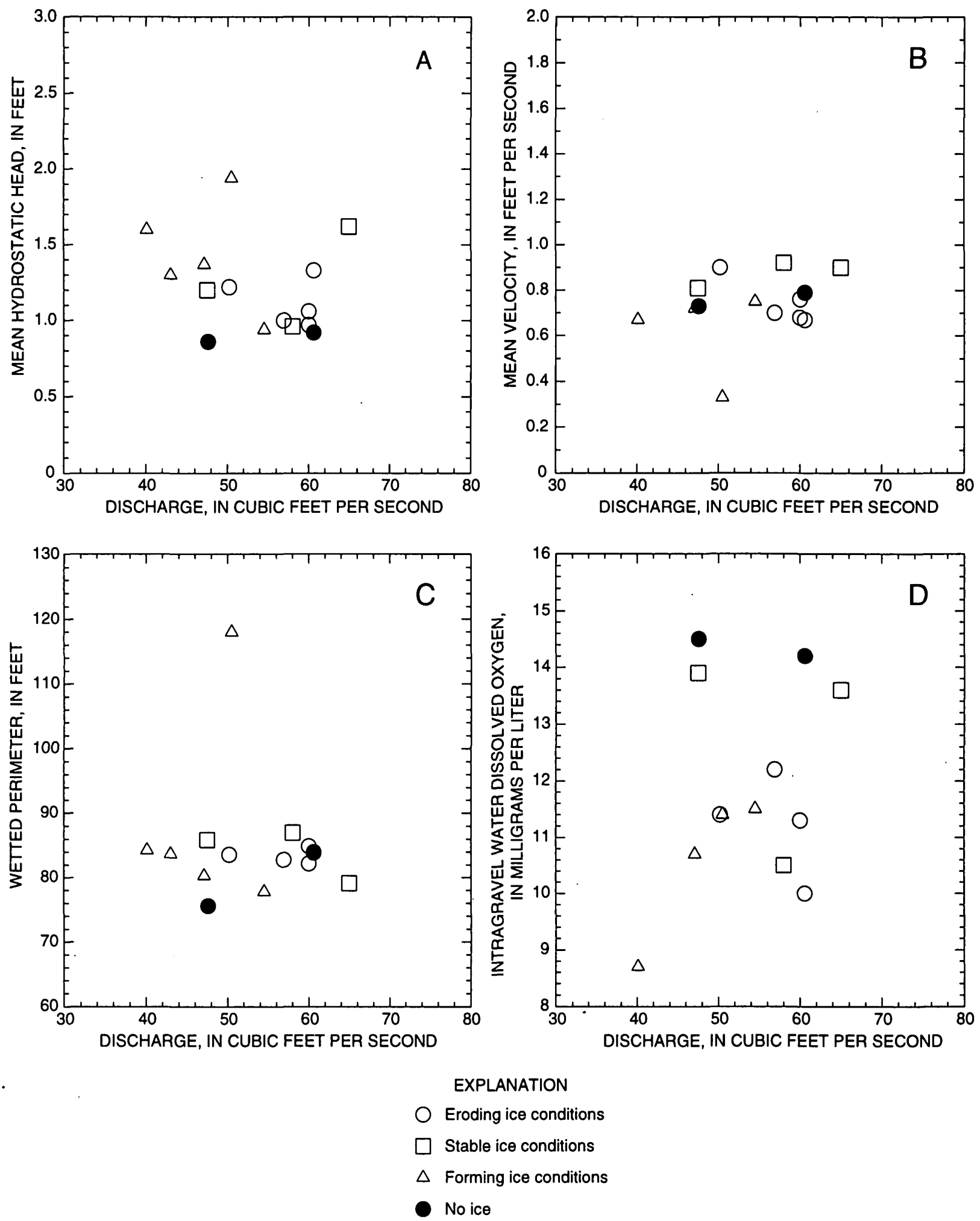

Figure 19. Selected physical properties relative to discharge, Bradley River at Upper Riffle Reach transect. (See figure 3 for transect location.) 

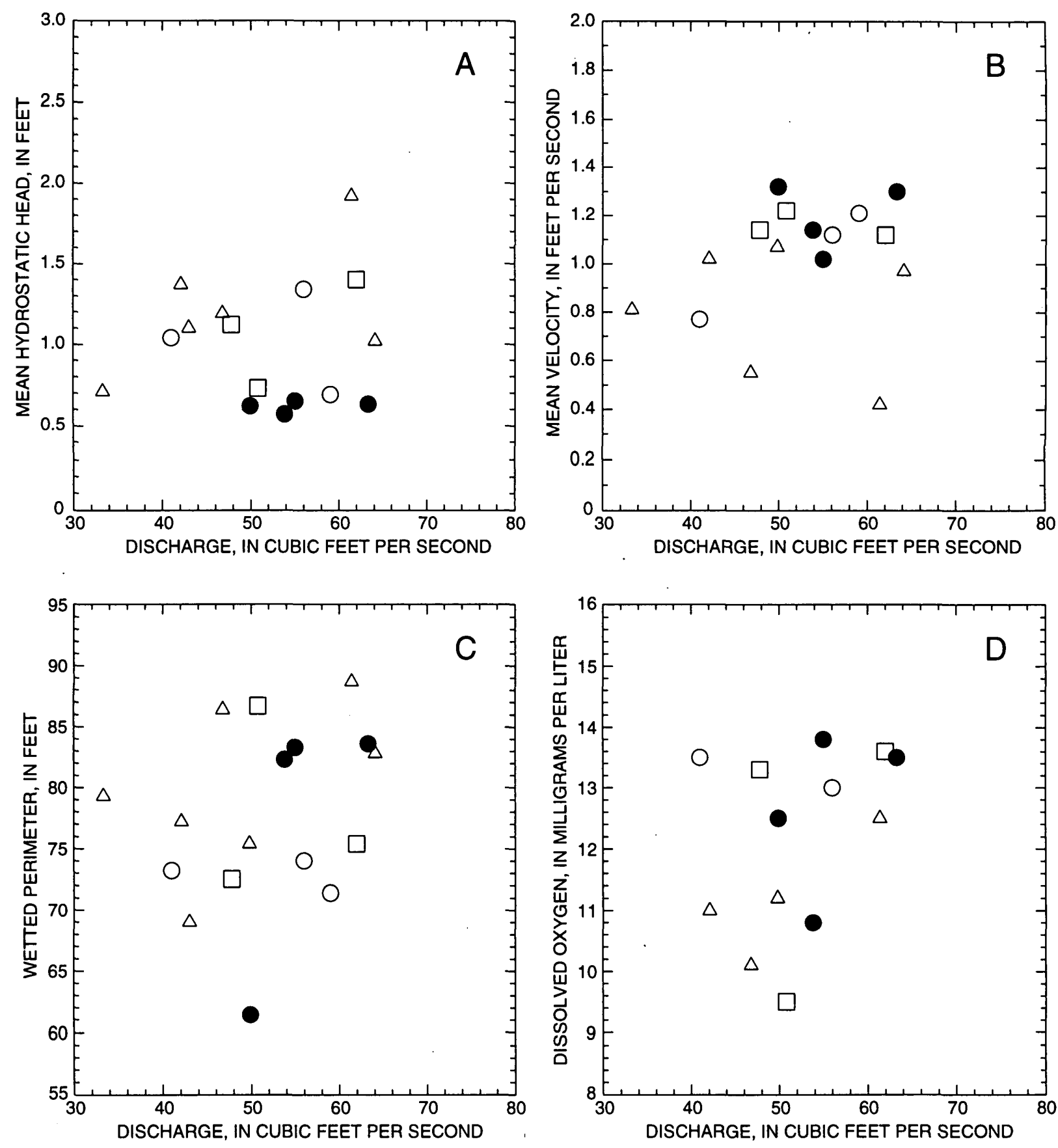

EXPLANATION

$O$ Eroding ice conditions

$\square$ Stable ice conditions

$\triangle$ Forming ice conditions

- No ice

Figure 20. Selected physical properties relative to discharge, Bradley River at Lower Riffle Reach transect. (See figure 3 for transect location.) 
winter needed for pink salmon incubation and fry development have been reported as $0.5 \mathrm{ft} / \mathrm{s}$ (Woodward-Clyde, 1983, p. 47) and greater than $1 \mathrm{ft} / \mathrm{s}$ (Reiser and White, 1981). The instream flow model used by Woodward-Clyde (1983, p. A5) chose 0.5 to $8 \mathrm{ft} / \mathrm{s}$ as optimum velocities for embryo development. These previous studies do not state whether velocity is measured at the water surface or near the streambed, or whether it is a mean velocity for the entire river reach. For this report, mean velocities are the average of several point velocities taken at numerous points within a transect at the time of measurement (Rickman, 1998, p. 5).

Mean surface-water velocities (non-tide affected) measured in the lower Bradley River ranged from $0.33 \mathrm{ft} / \mathrm{s}$ at Upper Riffle Reach on January 12, 1995 (discharge, $50.5 \mathrm{ft}^{3} / \mathrm{s} ; 100$ percent ice cover, forming) to $1.90 \mathrm{ft} / \mathrm{s}$ at the Bear Island transect on January 9, 1997 (discharge, $41.4 \mathrm{ft}^{3} / \mathrm{s} ; 100$ percent ice cover, stable). The average mean velocity for all transects during this study was $0.93 \mathrm{ft} / \mathrm{s}$ (standard deviation $0.28, \mathrm{n}=103$ ). The smallest mean velocity measured for each of the transects occurred on January 11 and 12, 1995 during a prolonged period of river icing (discharge ranged from 42.6 to $62.7 \mathrm{ft}^{3} / \mathrm{s}$; ice cover ranged from 80 to 100 percent, forming). Mean velocities on January 11 and 12 ranged from 0.33 to $0.49 \mathrm{ft} / \mathrm{s}$ (no data available for Tidewater and Tree Bar Reach transects). This period of extended icing and low mean velocities may have caused embryo mortality, and contributed to the low escapement in 1996 (fig. 12).

Mean velocities plotted against discharge for various ice conditions (figs. 15B-20B) indicate no clear difference in mean velocity among forming, stable, eroding, and ice-free conditions for the transects. The exceptions were at the Bear Island transect, where mean velocities decreased during periods when ice was present, and at the Tree Bar Reach transect, where mean velocities decreased during periods of forming and stable ice.
Surface-water velocities were observed to decrease during high tide at all the transects. Surface-water velocities commonly decreased to near zero at Upper and Lower Riffle Reaches during extremely high tides, and reverse flow over the top of the ice was observed on January 9, 1997.

Surface-water velocity distribution within a transect varies widely with changing ice conditions (Rickman, 1995, 1996, 1998). An example of velocity distribution changes caused by ice formation at the Tree Bar Reach transect is shown in figure 21. Selected water-surface velocity distributions for the six transects in the lower Bradley River are presented in figure 22 . Each episode of ice formation causes different and unique velocity distributions. None of the observed velocities were high enough to cause channel scour.

Data from figures 15B through 20B are summarized in table 2, which indicates the ice conditions under which the velocity would be adequate at 40,35 , and $30 \mathrm{ft}^{3} / \mathrm{s}$. Statistical analysis is inconclusive, given the small number of data points for each ice condition and the large scatter in the data.

Table 2. Ice conditions for which mean velocity is likely to exceed 0.5 foot per second for various discharges [N, no ice; E, eroding ice; $\mathrm{F}$, forming ice; $\mathrm{S}$, stable ice]

\begin{tabular}{ccccccc}
\hline \multirow{2}{*}{$\begin{array}{c}\text { Discharge } \\
\text { (cubic }\end{array}$} & \multicolumn{5}{c}{ Ice condition } \\
\cline { 3 - 7 } $\begin{array}{c}\text { feet per } \\
\text { second) }\end{array}$ & $\begin{array}{c}\text { Bear } \\
\text { Island }\end{array}$ & $\begin{array}{c}\text { Tide- } \\
\text { water }\end{array}$ & $\begin{array}{c}\text { Tree Bar } \\
\text { Reach }\end{array}$ & $\begin{array}{c}\text { Below } \\
\text { Fish } \\
\text { Camp }\end{array}$ & $\begin{array}{c}\text { Upper } \\
\text { Riffle } \\
\text { Reach }\end{array}$ & $\begin{array}{c}\text { Lower } \\
\text { Riffle } \\
\text { Reach }\end{array}$ \\
\hline 40 & NES & NES & NEFS & NES & NES & NES \\
35 & NES & NES & NE & NES & NES & NES \\
30 & NE & NES & NE & NS & NS & NES \\
\hline
\end{tabular}

Surface-water velocities within each transect are greater than $0.5 \mathrm{ft} / \mathrm{s}$ for discharges greater than $40 \mathrm{ft}^{3} / \mathrm{s}$, except during some iceforming events. During these events, intragravel water flow may be driven by increased hydrostatic pressure. 

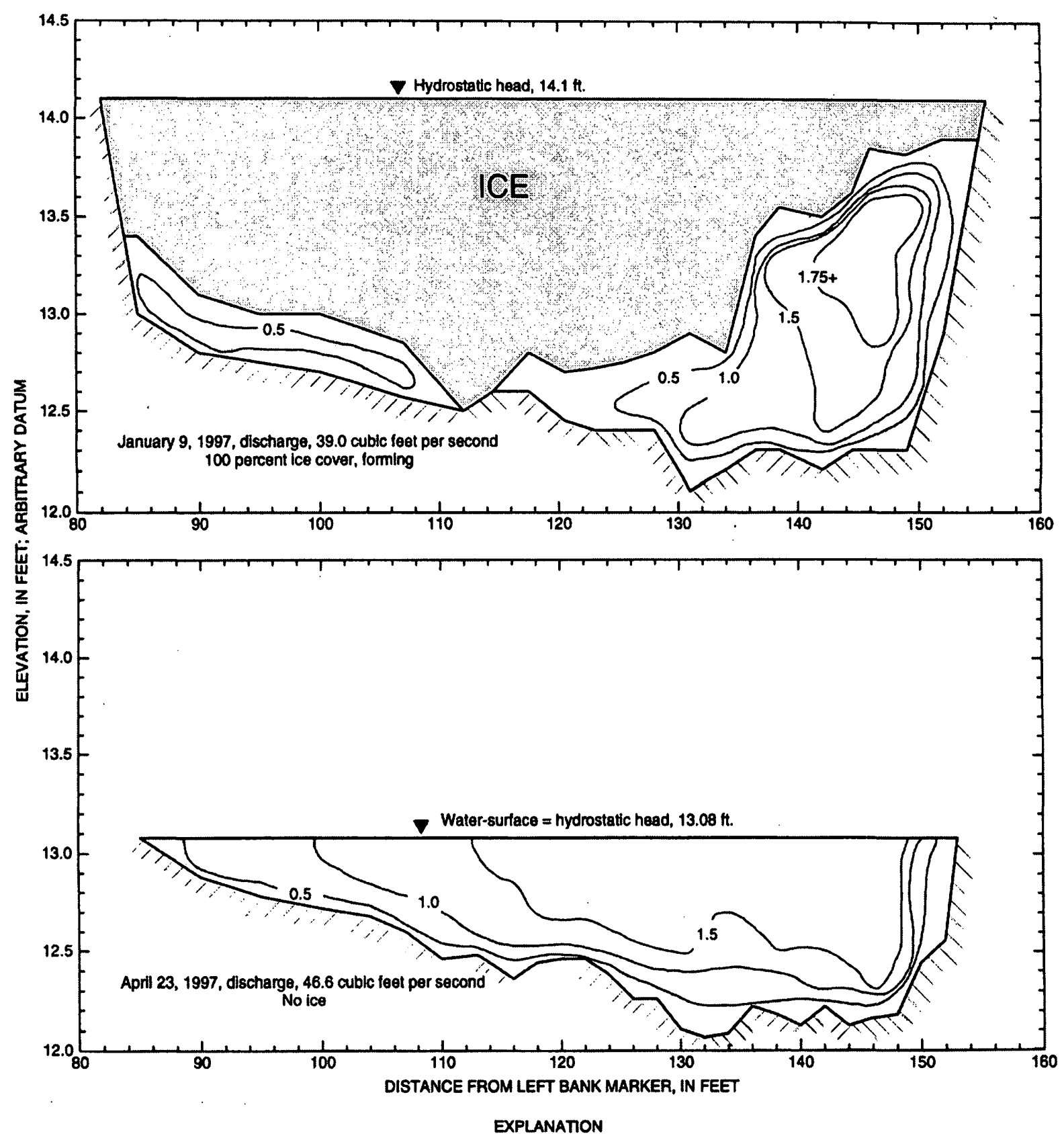

-1.5 - Line of equal velocty, in feet per second

Figure 21. Lines of equal velocity for selected ice-forming and ice-free conditions for Bradley River at Tree Bar Reach. 


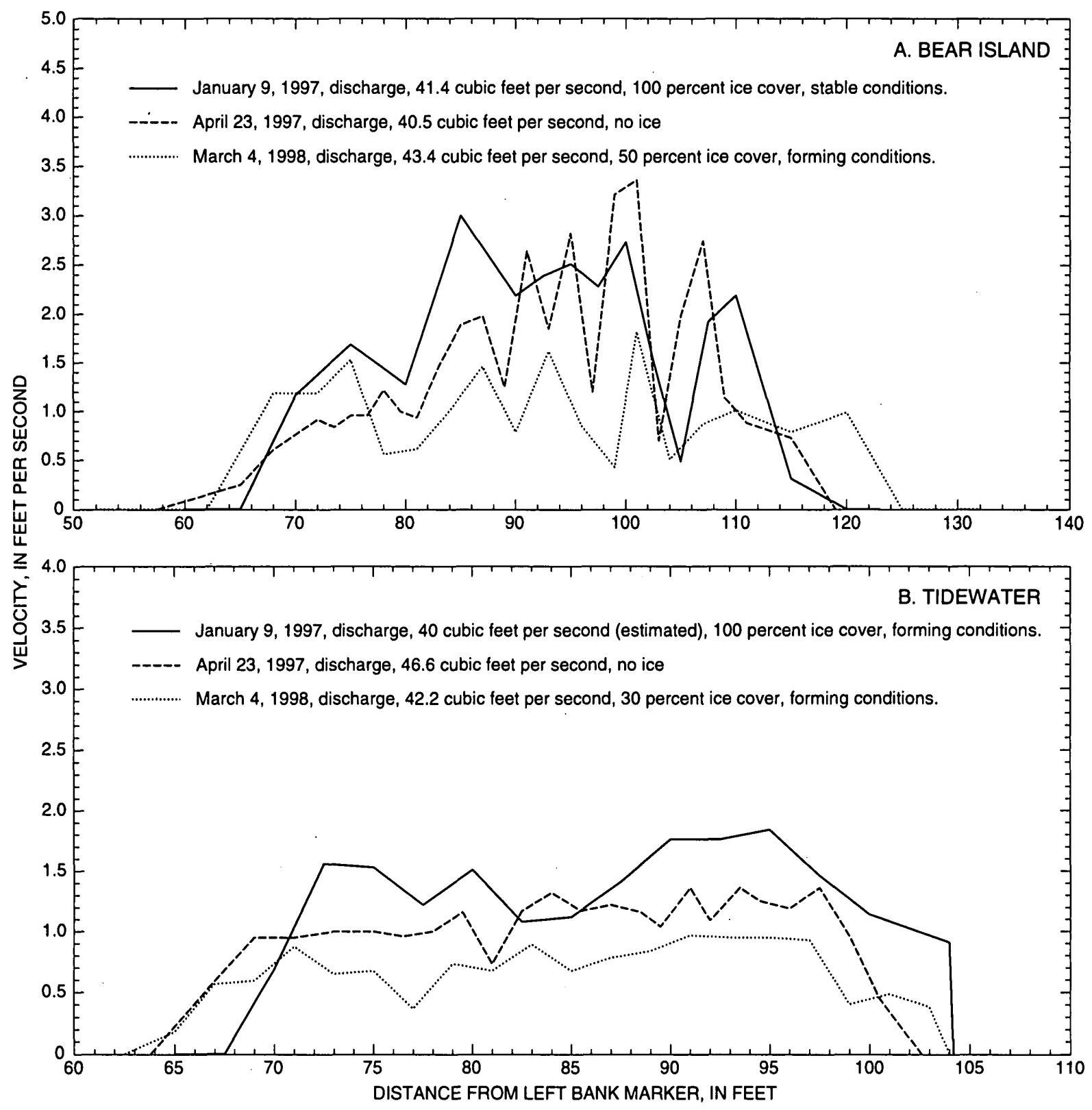

Figure 22. Selected surface-water velocity distributions for the six transects in the lower Bradley River. (Graphs are displayed in downstream order from A to F. See figure 3 for transect locations.) 


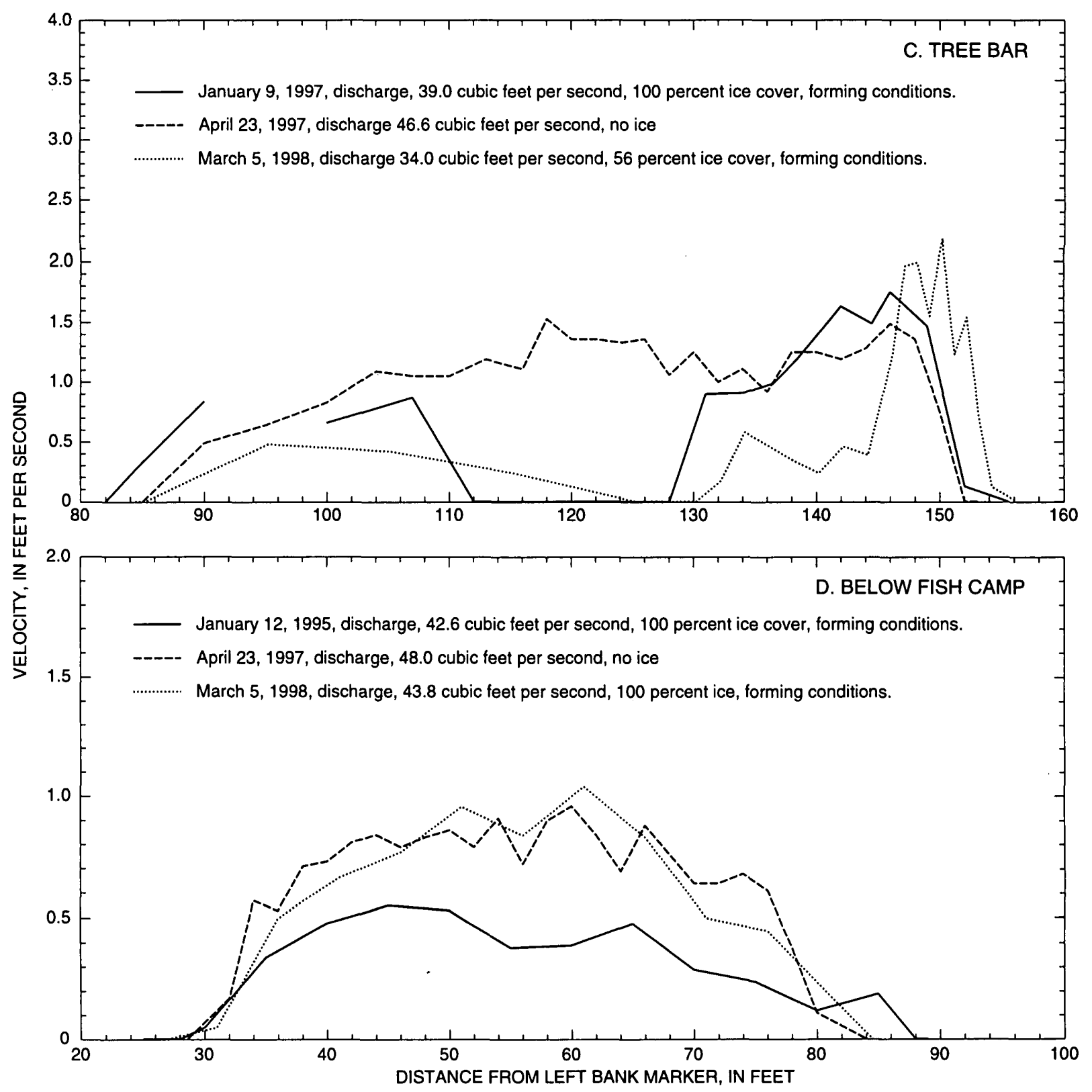

Figure 22. Continued. 


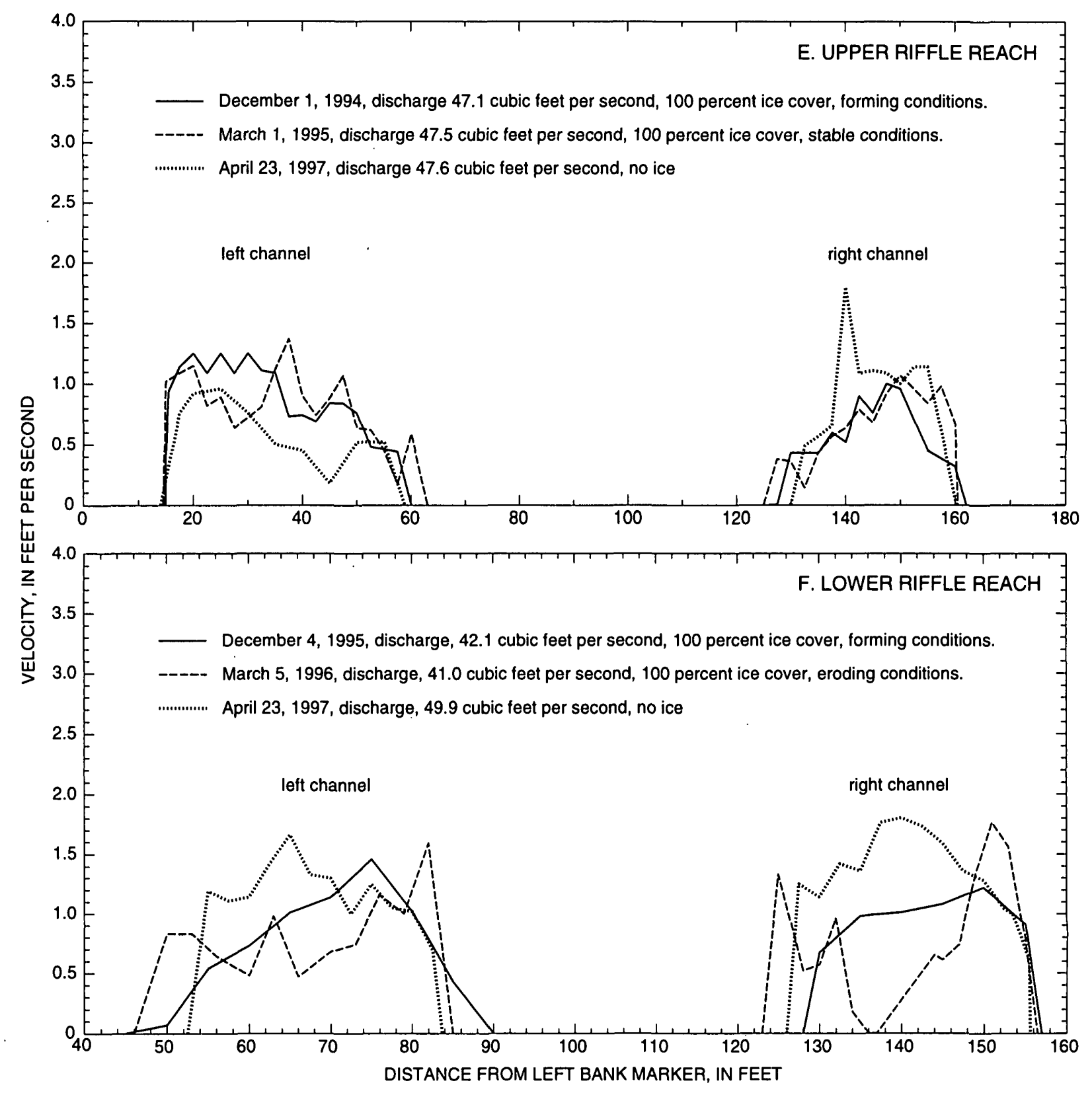

Figure 22. Continued. 
The long-term minimum discharge for which mean velocities can be expected to remain larger than $0.5 \mathrm{ft}$, is estimated at 35 $\mathrm{ft}^{3} / \mathrm{s}$, based on observations of velocity for stable and eroding ice conditions. The minimum discharge limit for an unexpected decrease in flow is about $30 \mathrm{ft}^{3} / \mathrm{s}$, based on surface-water velocity requirements alone. During a rapid flow decrease, water level would decline, reducing hydrostatic pressure. The ice may become bridged, in which case velocity characteristics, in the absence of anchor ice, would be the same as for open-water (ice free) conditions. The ice may collapse leading to a wide possibility of velocity distributions.

\section{Wetted Perimeter}

Wetted perimeter is defined for this report as the part of the streambed within a transect that is wetted by surface water, and does not include the ice/water boundary. Before flow regulation in the lower Bradley River, wetted perimeter during summer spawning was much larger than that during the winter salmon incubation period. As a result, many of the eggs deposited during the summer were dewatered and frozen during the winter, resulting in a high mortality rate (Woodward-Clyde, 1983, p. 47; Rickman, 1993, p. 12). The Woodward-Clyde instream flow study showed little difference in wetted perimeter (less than 15 percent) for flows between 30 and $50 \mathrm{ft}^{3} / \mathrm{s}$, but did not account for a possible increase caused by ice formation. Rundquist and Baldrige (1990, p. 82) suggested that incubation habitat would encompass 98.6 percent of the usable spawning habitat (assuming a discharge of $100 \mathrm{ft}^{3} / \mathrm{s}$ during spawning) at $40 \mathrm{ft}^{3} / \mathrm{s}$ and 97.2 percent at 30 $\mathrm{ft}^{3} / \mathrm{s}$.

Wetted perimeter data for March 1993 through April 1998 have been reported previously (Rickman, 1995, 1996, and 1998). Wetted perimeter (non-tide affected) ranged from $35.6 \mathrm{ft}$ at the Tidewater transect (March 11, 1993; discharge, $56.0 \mathrm{ft}^{3} / \mathrm{s}$; less than 10 percent ice cover, eroding) to $130.5 \mathrm{ft}$ measured at the Bear Island transect (December 4, 1995; discharge, $46 \mathrm{ft}^{3} / \mathrm{s}$ (estimated); 100 percent ice cover, forming). The Tree Bar Reach transect had the least variability (range, 64.6 to $79.0 \mathrm{ft}$ ) because of steep streambanks. The Bear Island transect had the greatest variability (range, 60.0 to $130.5 \mathrm{ft}$ ) because the channel is wide and shallow, with low-angle streambanks. Wetted perimeter was observed to be largest at extremely high tides. When ice was present in the river, water that was backed up from high tides would commonly inundate the ice cover.

No consistent relation exists between ice cover and wetted perimeter (figs. 15C-20C). Wetted perimeter usually increased during periods of forming and stable ice conditions. The largest measured wetted perimeter for each of the six transects occurred during periods of forming ice. Wetted perimeter was smallest for all transects, except at Upper and Lower Riffle Reaches, where ice shelves along the banks collapse and then freeze to the streambed. Dry or frozen surface gravels were found when coring through the ice. The smallest observed wetted perimeter for the Upper and Lower Riffle Reach transects occurred on April 23, 1997 during a period of no ice, following a relatively small high tide. Streambanks were choked with mud, which was presumably carried in with the tide that had washed over the newly thawed mud flats of upper Kachemak Bay. Sediment influxes from high tides were not observed at any other time during this study, presumably because the mud flats are frozen. The influx of sediment observed on April 23, 1997 probably had no adverse impact on the salmon because they should have already emerged from the streambed gravels.

Active bank scour, observed on the right bank of the right channel at the Lower Riffle Reach transect, may increase wetted perimeter over time. Rapid water movement over ice cover and bank gouging from iceberg movement with incoming and outgoing tides are the 
predominant causes of this bank scour. Scour is not occurring as rapidly at the other transects because their banks have deep rooted vegetation and the forces exerted by the tide decrease with distance upstream.

When the streamflow was rapidly reduced on March 4, 1998 (from 62 to $43 \mathrm{ft}^{3} / \mathrm{s}$ in 3.5 hours), the ice cover sagged in the middle of the channel and became bridged along the streambanks. Wetted perimeter decreased. The rapid decrease in discharge occurred during a period of forming ice, so the decrease in wetted perimeter was offset by the continued formation of anchor ice.

Wetted perimeter does not appear to be a function of discharge for any given type of ice cover. Graphs of discharge plotted against wetted perimeter (figs. 15C-20C) show a wide scatter in the data with few or no trends. The dominant controlling factors for wetted perimeter appear to be not discharge, but rather anchor ice, collapsed ice shelves, and bank scour caused by the movement of ice blocks with tide peak recession.

\section{Field Water-Quality Data}

\section{Temperature}

Development rate, survival, size of hatched alevins, and the percentage of deformities are related to water temperature during salmon incubation (Groot and Margolis, 1991, p. 156, 159). Cold water is able to hold a higher concentration of dissolved oxygen than warm water, which is beneficial to salmon embryo development. Water that is too cold retards development. Severe icing of the streambed can cut off oxygen supplies to the intragravel water. Development rate varies widely among fish stocks. Development rate is proportional to thermal input, which is expressed in degreedays Celsius. Stock differences between and within pink salmon populations permit adaptive adjustments in hatching and emergence timing to the thermal characteristics of individ- ual streams.(Groot and Margolis, 1991, p. 159). The development rate for the lower Bradley River stock has not been investigated.

The exact time of emergence in the lower Bradley River is not known, but is suspected to be late March or early April. Godin (1980, p.741) reported a range of 450 to 640 degreedays from hatching to emergence for pink salmon. Intragravel-water temperature data for Bradley River near Tidewater from January 1 to April 1 were used to calculate thermal input from hatching to emergence for the lower Bradley River (table 3). Thermal input for the lower Bradley River is much lower than that reported by Godin.

Table 3. Mean intragravel-water temperature and thermal input from January 1 to April 1 [ ${ }^{\circ} \mathrm{C}$, degree Celsius; ${ }^{\circ} \mathrm{C}$-days, degree-days Celsius]

\begin{tabular}{lcccccc}
\hline \multicolumn{1}{c}{ Data type } & 1993 & 1994 & 1995 & 1996 & 1997 & 1998 \\
\hline $\begin{array}{l}\text { Mean intragravel- } \\
\text { water tempera- } \\
\text { ture ( }\end{array}$ & 0.9 & 1.2 & 1.1 & 0.6 & 1.1 & 0.6 \\
$\begin{array}{l}\text { Thermal input } \\
\text { ('C-days) }\end{array}$ & 80 & 106 & 99 & 58 & 103 & 58 \\
\hline
\end{tabular}

Intragravel-water temperature is generally warmer than surface-water temperature during the winter months in glaciated streams (Baldrige and Trihey, 1982). This is true for the lower Bradley River where the intragravelwater temperature is generally 0.5 to $1.0{ }^{\circ} \mathrm{C}$ warmer than that for surface water (Rickman, 1996, 1998). Surface-water temperatures measured at all the transects were within $0.5^{\circ} \mathrm{C}$ of each other on any given date (Rickman, 1995, 1996, and 1998). Surface-water temperature was usually $0{ }^{\circ} \mathrm{C}$ during periods of ice formation, regardless of discharge. Changes in surface and intragravel-water temperature were mostly a function of periodic warm rains. Neither surface- nor intragravel-water temperatures are expected to change at lesser discharges of 30 to $40 \mathrm{ft}^{3} / \mathrm{s}$ in the lower Bradley River. 


\section{Dissolved Oxygen}

Adequate intragravel-water dissolved oxygen is necessary for salmon incubation success. The U.S. Environmental Protection Agency (USEPA, 1977) recommends a minimum of $5 \mathrm{mg} / \mathrm{L}$ dissolved oxygen to protect early life stages of cold water biota. Exchange of surface water with intragravel water is largely responsible for the maintenance of intragravel dissolved oxygen (Vaux, 1968). This exchange is controlled by depth and velocity of surface water, channel morphology, and streambed permeability (Wickett, 1954; Coble, 1961; Shumway and others, 1964; Chapman and McLeod, 1987).

Dissolved-oxygen data for the lower Bradley River have been previously reported (Rickman, 1995, 1996, and 1998) and are summarized in the form of boxplots (fig. 23). Concentrations of surface-water dissolved oxygen ranged from $9.5 \mathrm{mg} / \mathrm{L}$ at the Tidewater transect on March 18, 1997 (discharge $53.7 \mathrm{ft}^{3} / \mathrm{s} ; 40$ percent ice cover, forming; water temperature $0.0{ }^{\circ} \mathrm{C}$ ) to $15.0 \mathrm{mg} / \mathrm{L}$ at the below Fish Camp transect on December 1, 1994 (discharge 48.4 $\mathrm{ft}^{3} / \mathrm{s} ; 100$ percent ice cover, forming; water temperature, $0 .{ }^{\circ} \mathrm{C}$ ). Statistical analysis of these data using the Kruskal-Wallis test (Helsel and Hirsch, 1992) indicates no statistically significant difference in the median surface-water dissolved-oxygen concentrations among the six transects $(\alpha=0.05)$. Thus, surface-water dissolved-oxygen concentrations at the six transects are considered to be similar. Dissolved oxygen in surface water, expressed as percent saturation, ranged from 67 to 103 percent. The high saturation is expected because water discharged from the fish-water bypass and tributary streams flows over numerous waterfalls before entering the lower Bradley River.

Dissolved oxygen concentrations of intragravel water ranged from $8.2 \mathrm{mg} / \mathrm{L}$ at the Tree Bar Reach transect on March 4, 1996 (discharge $48.8 \mathrm{ft}^{3} / \mathrm{s}$; less than 20 percent ice cover, eroding; $0.60 \mathrm{ft}$ hydrostatic head of water above streambed; surface-water velocity $0.76 \mathrm{ft} / \mathrm{s}$; intragravel-water temperature $0.5{ }^{\circ} \mathrm{C}$ ) to 15.3 $\mathrm{mg} / \mathrm{L}$ at the below Fish Camp transect on April 23, 1997 (discharge $48.0 \mathrm{ft}^{3} / \mathrm{s}$; no ice; $1.22 \mathrm{ft}$ hydrostatic head of water above streambed; surface-water velocity $0.64 \mathrm{ft} / \mathrm{s}$; intragravelwater temperature $1.5{ }^{\circ} \mathrm{C}$ ). All dissolved-oxygen concentrations were well above the 5.0 $\mathrm{mg} / \mathrm{L}$ concentration recommended by the USEPA. Statistical analysis of these data using the Kruskal-Wallis test (Helsel and Hirsch, 1992) indicates no statistically significant difference in the median intragravel-water dissolved-oxygen concentrations among the six transects $(\alpha=0.05)$. Intragravel-water dissolved-oxygen concentrations at the six transects are considered to be similar.

Statistical analysis using the sign test (Helsel and Hirsch, 1992) indicates that surface-water dissolved-oxygen concentrations are higher than intragravel-water dissolvedoxygen concentrations ( $p=0.005)$. This is not unexpected because intragravel-water temperatures are slightly warmer than surface-water temperatures; thus, intragravel-water dissolved-oxygen saturation levels are lower and intragravel water does not have direct contact with the atmosphere. Variance in the intragravel-water concentrations is much greater than in the surface-water concentrations. The reasons for this include variations in streambed permeability, depth of water, and velocity between the intragravel-water dissolved-oxygen sampling sites, and sampling error.

Intragravel water was commonly found to contain a large quantity of silt when first pumped, but would usually clear up after the first $60 \mathrm{~mL}$ were pumped. This initial high silt content is caused by disturbance to the gravels when the probe is inserted into the streambed. There was no correlation between silt content (visual examination) and dissolved-oxygen content. There are no indications that intragravel-water dissolved-oxygen levels decreased as the winter progressed. 


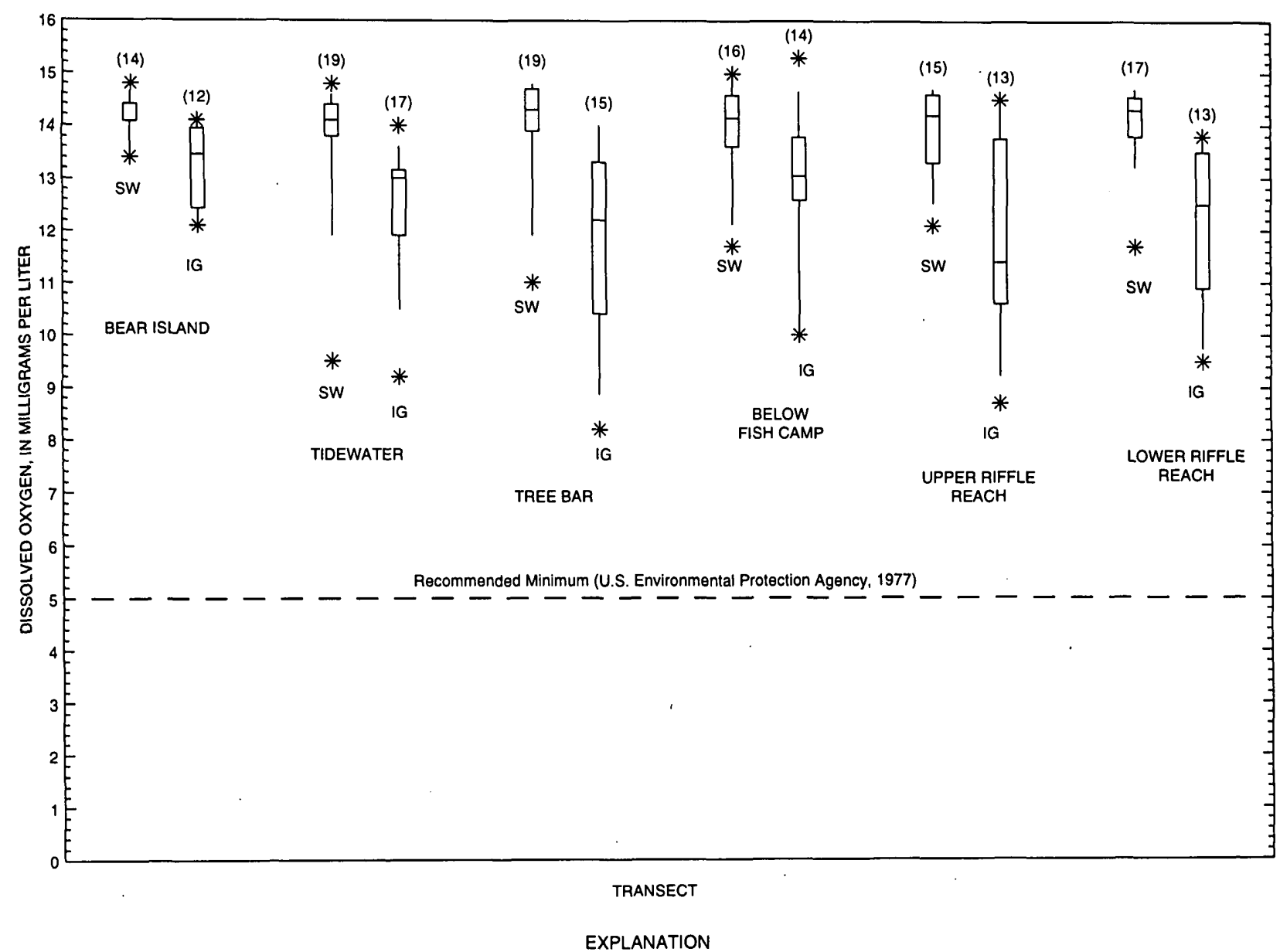

Dissolved oxygen concentration

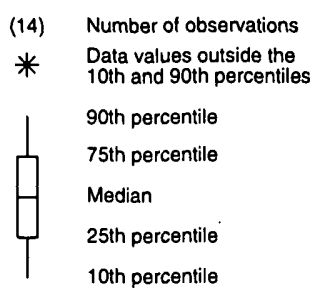

$S W=$ Surface-water

IG = Intragravel-water

Figure 23. Surface- and intragravel-water dissolved-oxygen concentrations at the six transects of the lower Bradley River. (See figure 3 for transect location.) 
No clear relations exist between percent ice cover, discharge, and intragravel-water dissolved-oxygen concentrations (figs. 15D-20D). Observed intragravel- and surface-water dissolved-oxygen concentrations were adequate for salmon egg, alevin, and fry development at stream-water discharges greater than $40 \mathrm{ft}^{3} / \mathrm{s}$ at all six transects. These data indicate that adequate intragravel-water dissolved-oxygen concentrations occur at discharges as low as 30 $\mathrm{ft}^{3} / \mathrm{s}$ for short durations where fine-sediment deposition would be small. The data are not sufficient to determine effects of discharges less than $40 \mathrm{ft}^{3} / \mathrm{s}$ for longer time periods.

\section{Specific Conductance}

The extent of intrusion of seawater into the lower Bradley River during periods of high tides is a function of river discharge (Woodward-Clyde, 1983, p. 48). Seawater intrusion most likely occurs during the winter months when river discharge is lowest. Pink salmon commonly spawn in intertidal zones. Pink salmon eggs and alevins are tolerant to short exposures to seawater (Groot and Margolis, 1991, p. 156). The Woodward-Clyde study (1983, p. 55) showed that seawater intrusion would not be a factor within the study reach. The specific conductance of seawater is much higher than that of fresh water, and can be used as an indicator of seawater intrusion. Specific conductance may also be an indicator of ground-water contribution to stream discharge (Riggs, 1972, p. 12).

Specific conductance data for the lower Bradley River have been previously reported (Rickman, 1995, 1997, and 1998). Specific conductance ranged from 59 to $77 \mu \mathrm{S} / \mathrm{cm}$ and did not vary significantly spatially or temporally. There was no indication of seawater intrusion from measurements taken immediately following high tides (March 1993, November to December 1994, January 1997) which caused river water to back up in the study reach. Ground-water contributions to total river dis- charge cannot be determined from the specific conductance data. Specific conductance is not a limiting factor for determining the effects of lesser flows on salmon incubation habitat in the lower Bradley River.

\section{Fine-Sediment Deposition and Streambed Permeability}

\section{Fine-Sediment Deposition}

Fine sediment is a natural component of glacial stream water. The precise definition of fine sediment varies from study to study (Chapman and McLeod, 1987), ranging from less than 0.83 to less than $9.5 \mathrm{~mm}$ (Chapman, 1988). Large quantities of fine sediment in salmon spawning beds can have severe adverse impacts on incubating salmon (Chapman and McLeod, 1987; Groot and Margolis, 1991). Fine-sediment deposition reduces gravel permeability, which can reduce intragravel flow and decrease intragravel dissolved oxygen (Vaux, 1968; Wickett, 1954; Woods, 1980). Wickett found good survival in the presence of much surface sediment if adequate intragravelwater upwelling occurred. Large quantities of sediment can also hamper alevin movement and fry emergence.

When a female salmon digs the redd, the gravel is moved around enough to wash out the fines, leaving relatively clean gravel. Large salmon populations can result in removal of significant quantities of fine-grained sediment from entire rivers (Chapman, 1988). Fine sediment can slowly fill the redd during the time of egg incubation, hatching, and emergence.

Suspended-sediment concentrations are usually high in the lower Bradley River because of glacial-melt water released at the fish-bypass (fig.1), except in late spring when, for a period of a few days, most of flow in the lower Bradley River comes from snowmelt in the North and lower Middle Forks Bradley River (both are clearwater streams). Streamflow in the lower 
Bradley River between November and late April is almost always very turbid, especially in December and January when flow contributions from the North and lower Middle Forks Bradley River are generally small.

A common measurement for fine-sediment deposition is embeddedness, which requires visual "hands on" sampling. This method is not practical for turbid steams, such as the lower Bradley River. The entire study reach was systematically observed using a view tube in late April and October 1997 to identify areas of sediment deposition. The study reach was viewed again in great detail on June 4, 1997, when stream water was very clear. Silt deposition using visual methods was not readily apparent in the glide and riffle areas, but was apparent in the deep pools immediately upstream and downstream from the Below Fish Camp transect. However, visual methods of embeddedness are unreliable when fines are silt and clay size $(0.00024$ to $0.0625 \mathrm{~mm})$ (J.W. Burns and R.E. Edwards, Payette National Forest, written commun., 1985) as found in the lower Bradley River. Stirring the streambed gravels released clouds of silt throughout the study reach. The quantity of deposited silt increased markedly (qualitatively observed when stirring up streambed gravels) beginning $400 \mathrm{ft}$ downstream from the Below Fish Camp transect. The streambed at this point has a "soft" feel when walking on it.

Rundquist and others (1985, p. 86) noted deposition of fine sediment up to $0.3 \mathrm{ft}$ thick in dewatered areas at Upper and Lower Riffle Reaches during winter flows. Field observations at the Upper and Lower Riffle Reaches showed similar deposits near gravel streambanks following high-tide cycles. Wetted perimeter at the Lower Riffle Reach transect was reduced 20 percent by fine-sediment deposition following a moderately high tide on April 23, 1997. The source of this fine sediment was probably the extensive recently thawed mud flats in the lower Bradley River Basin below the study area.
Fine-sediment deposition is directly related to sediment quantity and particle size, and inversely related to shear velocity. Shear velocity is defined using the following equation (Chow, 1959, p. 201):

$$
V f=[g R S]^{0.5}
$$

where $V f$ is the shear velocity, in feet per second; $g$ is the acceleration due to gravity, 32 $\mathrm{ft} / \mathrm{s}^{2} ; R$ is the hydraulic radius in feet, defined as the stream cross-sectional area divided by the wetted perimeter; and $S$ is the slope of the energy line, in feet per foot.

If shear velocity is sufficiently high, fine sediment will not settle out of the water column. Alonso and Mendoza (1992) concluded that fine sediment will not be deposited if:

$$
\frac{W s}{V f}<0.01
$$

where $W s$ is the settling velocity, in feet per second. Standard settling velocities for quartz (table 4) were used to calculate the minimum velocity necessary to keep suspended sediment in suspension. Source materials for suspended sediment in the Bradley River basin are predominantly feldspars and metamorphosed

Table 4. Standard settling velocities for quartz particles and corresponding minimum shear velocities required to keep particles in suspension

[Data from D. Childers, USGS, written commun., 1986; velocity in feet per second]

\begin{tabular}{ccc}
\hline $\begin{array}{c}\text { Sediment fall } \\
\text { diameter } \\
\text { (millimeters) }\end{array}$ & Settling velocity & $\begin{array}{c}\text { Minimum shear } \\
\text { velocity }\end{array}$ \\
\hline 0.004 & $8.5 \times 10^{-5}$ & 0.008 \\
0.008 & $3.5 \times 10^{-4}$ & 0.035 \\
0.016 & $1.3 \times 10^{-3}$ & 0.13 \\
0.031 & $5 \times 10^{-3}$ & 0.50 \\
0.062 & $1.7 \times 10^{-2}$ & 1.7 \\
\hline
\end{tabular}


basalt, which are made up of minerals with specific gravities similar to those of quartz.

The suspended-sediment concentration for a sample collected on January 14, 1998 at the Tidewater transect was $76 \mathrm{mg} / \mathrm{L}$ (discharge $51.4 \mathrm{ft}^{3} / \mathrm{s} ; 100$ percent ice cover, forming), of which 99 percent of the suspended sediment was finer than $0.062 \mathrm{~mm}$. The sample did not contain enough sediment to accurately measure the range of particle size less than $0.062 \mathrm{~mm}$ diameter. However, analysis of a suspendedsediment sample collected on August 20, 1997 (outside of the period covered in this report) at the Below Fish Camp transect $(21 \mathrm{mg} / \mathrm{L}$ suspended sediment; discharge $126 \mathrm{ft}^{3} / \mathrm{s}$ ) found that 92 percent of the sediment particles were less than $0.016 \mathrm{~mm}$ diameter (Benson and others, 1998).

Shear velocities calculated for the six study transects are summarized in table 5 . Energy slope, $S$, was estimated using the hydrostatic head elevation difference between transects divided by the distance between the transects.

Table 5. Mean and range of shear velocities for the six transects in the lower Bradley River

\begin{tabular}{lcc}
\hline \multirow{2}{*}{ Transect } & \multicolumn{2}{c}{ Shear velocity, $V f$ in feet per second } \\
\cline { 2 - 3 } & Mean & Range \\
\hline Bear Island & 0.28 & 0.16 to 0.39 \\
Tidewater & 0.40 & 0.32 to 0.50 \\
Tree Bar Reach & 0.31 & 0.23 to 0.46 \\
Fish Camp & 0.26 & 0.17 to 0.39 \\
Upper Riffle Reach & 0.18 & 0.11 to 0.30 \\
Lower Riffle Reach & 0.20 & 0.13 to 0.26 \\
\hline
\end{tabular}

No relation was found between ice conditions and shear velocities. Shear velocity decreased with decreased discharge when no ice was present in the study transects. Shear velocities are not sufficient to keep particles $0.062 \mathrm{~mm}$ or larger in suspension. Shear veloc- ities (non-tide affected) were large enough to keep suspended particles less than $0.016 \mathrm{~mm}$ in suspension for all but two exceptions: both occurred at Upper Riffle Reach, on December 18,1996 (discharge $60.6 \mathrm{ft}^{3} / \mathrm{s} ; 100$ percent ice cover, eroding) and on February 12, 1997 (discharge $60.6 \mathrm{ft}^{3} / \mathrm{s}$; no ice). The range of shear velocities within each transect, indicates that fine-sediment deposition should be largest at the Upper and Lower Riffle Reach transects, which agreed with field observations. Shear velocities were largest at the Tidewater and Tree Bar Reach transects, where pink salmon spawning activity is the greatest within the study reach. Analysis of fine-sediment deposition caused by tide effect was beyond the scope of this study, but field observations noted significant fine-sediment deposition in the Upper and Lower Riffle Reach transects during some tide peak recessions.

Shear stress calculations indicate that a streamflow of $40 \mathrm{ft}^{3} / \mathrm{s}$ is adequate to prevent significant fine-sediment deposition in the lower Bradley River, except occasionally in the Upper and Lower Riffle Reach transects. Increased fine-sediment deposition (non-tide affected) resulting from unexpected decreases in flow would not be significant because of low suspended-sediment concentration, especially of particles larger than $0.016 \mathrm{~mm}$ diameter. Data are insufficient to determine fine-sediment deposition for long-term flows less than $40 \mathrm{ft}^{3} / \mathrm{s}$ for all possible ice conditions.

\section{Dissolved Oxygen Interchange}

Fine-sediment deposition reduces gravel permeability, which decreases the interchange between surface and intragravel waters. A method to quantify this is to look at the percentage of dissolved-oxygen interchange between surface and intragravel waters (Woods, 1980). Percentage of dissolved-oxygen interchange is defined using the equation:

$$
P=I / S \times 100
$$


where $P$ is the interchange percentage; $I$ is the intragravel-water dissolved-oxygen concentration; and $S$ is the surface-water dissolved-oxygen concentration.

Boxplots of the interchange percentages calculated for all six study transects are shown in figure 24. Interchange percentages ranged from 57 percent at Tree Bar Reach transect on March 4, 1996 (discharge $48.8 \mathrm{ft}^{3} / \mathrm{s}$; less than 20 percent ice cover, eroding) to 118 percent at the Tidewater transect on March 18, 1997 (discharge $53.5 \mathrm{ft}^{3} / \mathrm{s}$; 40 percent ice cover, forming). Statistical analysis of these data using the Kruskal-Wallis test (Helsel and Hirsch, 1992) indicates no statistically significant difference in dissolved-oxygen interchange percentages among the six transects $(\alpha=0.05)$. Dissolvedoxygen interchange was adequate for measured discharges as small as $33.3 \mathrm{ft}^{3} / \mathrm{s}$, and is likely to be adequate for discharges as low as $30 \mathrm{ft}^{3} / \mathrm{s}$ for short durations. Interchange is adequate for long-term discharges as low as $40 \mathrm{ft}^{3} / \mathrm{s}$. Existing data are insufficient for determining the lower limits of flow needed to ensure adequate dissolved-oxygen exchange for long durations, because of potential increase in fine-sediment deposition.

\section{Stranding}

Salmon fry occupying pools or gravels that are isolated from the active river flow are said to be stranded. Pink salmon fry probably emerge from the spawning gravels in late March and early April (Morrow, 1980, p. 65; John Morsell, Northern Ecological Services, oral commun., 1995). Salmon fry emerge through the gravel at a rate of up to $0.2 \mathrm{ft} / \mathrm{min}$ under favorable conditions (Groot and Margolis, 1991, p. 162). Rapid changes in river stage can leave emerging fry stranded along gravel bars, resulting in mortality. Rapid dewatering of gravel bars can result from temporary damming of the river during ice breakup, or from rapid decreases in flow downstream from reser- voirs (Becker and others, 1982). Rapid decreases in stage during tide recession may cause stranding in the lower Bradley River.

Stranding potential is increased as the gravel-bar slope decreases. Slope is measured from mid-channel, perpendicular to the direction of flow. Slopes of less than 4 percent are likely to cause stranding, whereas slopes greater than 9 percent are not (Prewitt and Whitmus, 1986). Streambank and gravel-bar slopes measured at the six study transects are presented in table 6. Slopes of non-gravel banks were not reported because emerging fry do not occupy these areas. The smallest slopes were found to be 4 percent on the left sides of the Bear Island and Lower Riffle Reach transects. Most of the slopes were greater than 9 percent.

Table 6. Gravel bar slopes at the six study transects [--,transect has a single channel; NA, bank is not usable salmon habitat]

\begin{tabular}{ccccc}
\hline & \multicolumn{4}{c}{ Percent slope } \\
\cline { 2 - 5 } Transect \\
\cline { 2 - 5 } & $\begin{array}{c}\text { Lig. 3) } \\
\text { main (left) } \\
\text { channel }\end{array}$ & $\begin{array}{c}\text { Right bank } \\
\text { main (left) } \\
\text { channel }\end{array}$ & $\begin{array}{c}\text { Left bank } \\
\text { right } \\
\text { channel }\end{array}$ & $\begin{array}{c}\text { Right bank } \\
\text { right } \\
\text { channel }\end{array}$ \\
\hline Bear Island & 4 & 6 & -- & -- \\
Tidewater & 9 & 17 & -- & -- \\
Tree Bar & 28 & NA & -- & -- \\
Fish Camp & 18 & 7 & -- & -- \\
Upper Riffle & NA & 10 & 10 & NA \\
Lower Riffle & 4 & 7 & 13 & NA \\
\hline
\end{tabular}

Examination of stage data from the USGS stream-gaging station Bradley River near Tidewater showed a maximum of $0.05 \mathrm{ft} / \mathrm{min}$ change in stage, which occurred with an outgoing tide. The largest rate of stage change from ice breakup was $0.01 \mathrm{ft} / \mathrm{min}$. Neither rate is considered fast enough to cause significant stranding of juvenile salmon.

On the morning of March 4, 1998, stream water release at the fish-water bypass was purposely reduced from about 41 to $22 \mathrm{ft}^{3} / \mathrm{s}$ to 


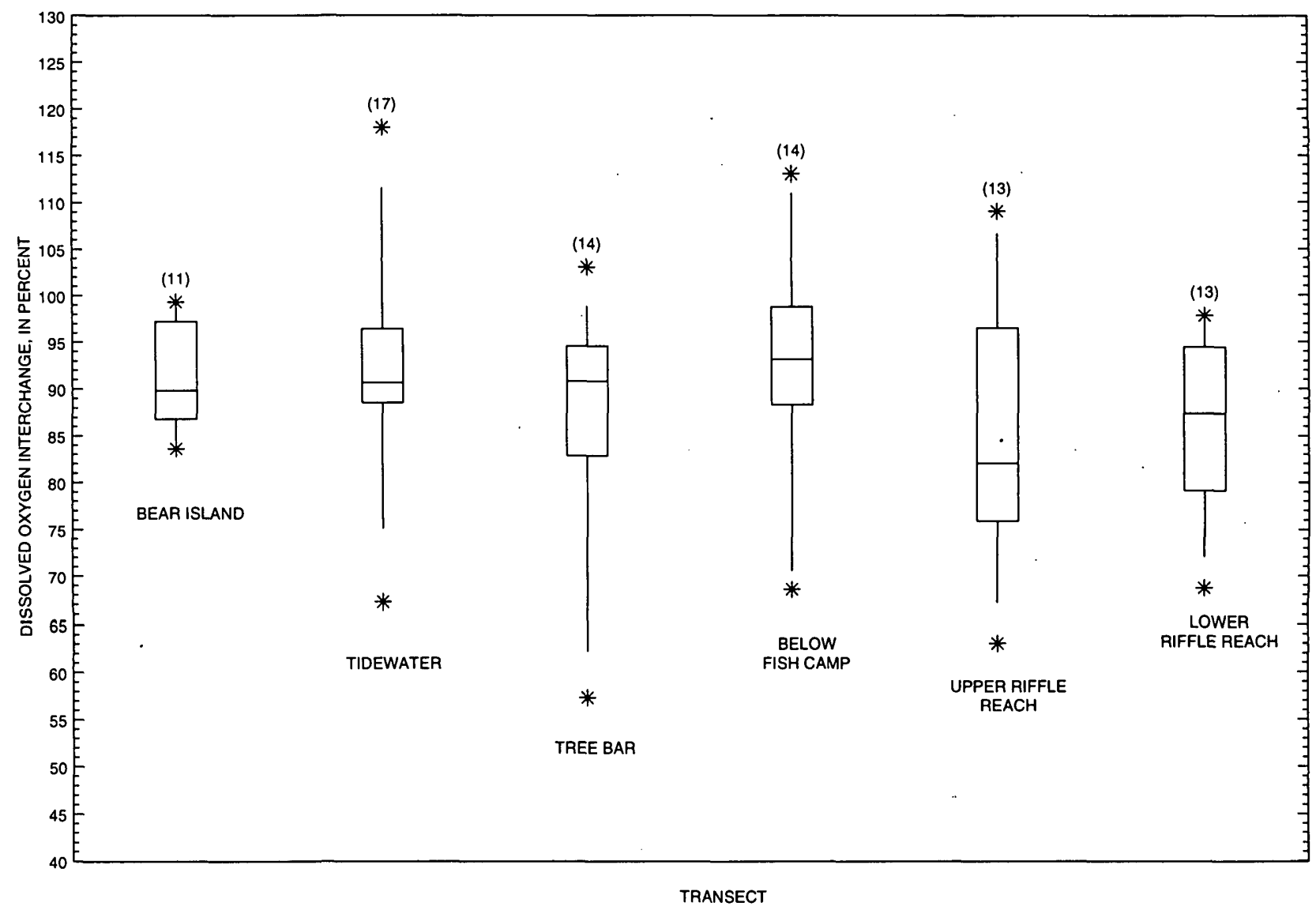

EXPLANATION

Dissolved oxygen percent interchange

(11) Number of observations

* Data values outside the

90th percentile

75th percentile

Median

25th percentile

10th percentile

Figure 24. Dissolved oxygen percent interchange at the six transects of the lower Bradley River. (See figure 3 for transect location) 
study the effects of a rapid decrease in flow in the lower Bradley River. Declines in stage caused by decreased flow were offset by increased formation of anchor ice. The decline in stage during this period, measured at the Tidewater transect, was $0.002 \mathrm{ft} / \mathrm{min}$.

\section{Discharge from the North and Lower Middle Forks Bradley River}

Discharge from the North and lower Middle Forks Bradley Rivers (fig. 1) is not adequate to meet minimum flow requirements in the lower Bradley River during the winter months, so additional flow is released from the dam through the fish-water bypass. Because winter flow contributions from the North and lower Middle Forks Bradley River are not well understood, additional water has been released from the fish-water bypass to ensure adequate flow at the FERC regulatory gaging station, Bradley River near Tidewater.

Instantaneous discharge measurements were made throughout the winters of 1993-96, and a stream-gaging station was installed in August 1996 to provide continuous streamflow record. Instantaneous discharge measurements from the 1993-96 water years and daily mean discharge data from the 1997-98 water years are shown in figure 25. Precipitation in the Bradley River basin was 80 percent of normal during the 1996-97 water years (U.S. Geological Survey, unpublished data), and this factor is reflected in the low discharges. Daily mean discharge during this study ranged from $2.5 \mathrm{ft}^{3} / \mathrm{s}$ on January $2-4,1997$ to $626 \mathrm{ft}^{3} / \mathrm{s}$ on November 9,1997 . The river was affected by ice backwater approximately 34 percent of the time between November 1 and April 30 for both 1997 and 1998 water years. Duration of iceaffected periods ranged from 3 to 35 days. Periods of ice cover were not documented during the 1993-96 water years. Increases in discharge from rain and melting snow occur periodically throughout the winter. Interpretation of realtime stage data, transmitted by radio, is difficult without visits to the gaging station to verify ice conditions.

Flow contributions from the North and lower Middle Forks Bradley River needed to maintain $40 \mathrm{ft}^{3} / \mathrm{s}$ in the lower Bradley River ranged from 6 to 100 percent. Discharge data are not available for enough years to develop accurate low-flow frequency curves. The maximum monthly fish-water bypass discharge can be estimated using discharge data from the Middle Fork below North Fork Bradley River stream-gaging station (table 7), with the following assumptions: (1) the reach between the fish-water bypass and the Bradley River near Tidewater stream-gaging station is steady or gaining (Rickman, 1993), and (2) discharge from the fish-water bypass is not temporarily obstructed by stream channel blockages, such as rock slides or avalanches. However, the data set used to generate table 7 is small and does not represent all possible flow conditions.

Table 7. Monthly minimum discharge measured at stream-gaging station Middle Fork Bradley River below North Fork Bradley River and estimated monthly maximum discharge needed from the fish-water bypass to meet minimum flow requirements in the lower Bradley River

\begin{tabular}{lllllll}
\hline & \multicolumn{5}{c}{ Discharge (cubic feet per second) } \\
\cline { 2 - 7 } Data type & Nov. & Dec. & Jan. & Feb. & Mar. & Apr. \\
\hline $\begin{array}{l}\text { Minimum } \\
\text { measured at } \\
\begin{array}{l}\text { stream gag- } \\
\text { ing station }\end{array}\end{array}$ & 6 & 2.8 & 2.5 & 6.6 & 5.2 & 5.3 \\
$\begin{array}{l}\text { Maximum } \\
\text { required } \\
\text { from fish- } \\
\text { water bypass }\end{array}$ & 34 & 37.2 & 37.5 & .33 .4 & 34.8 & 34.7 \\
\hline
\end{tabular}



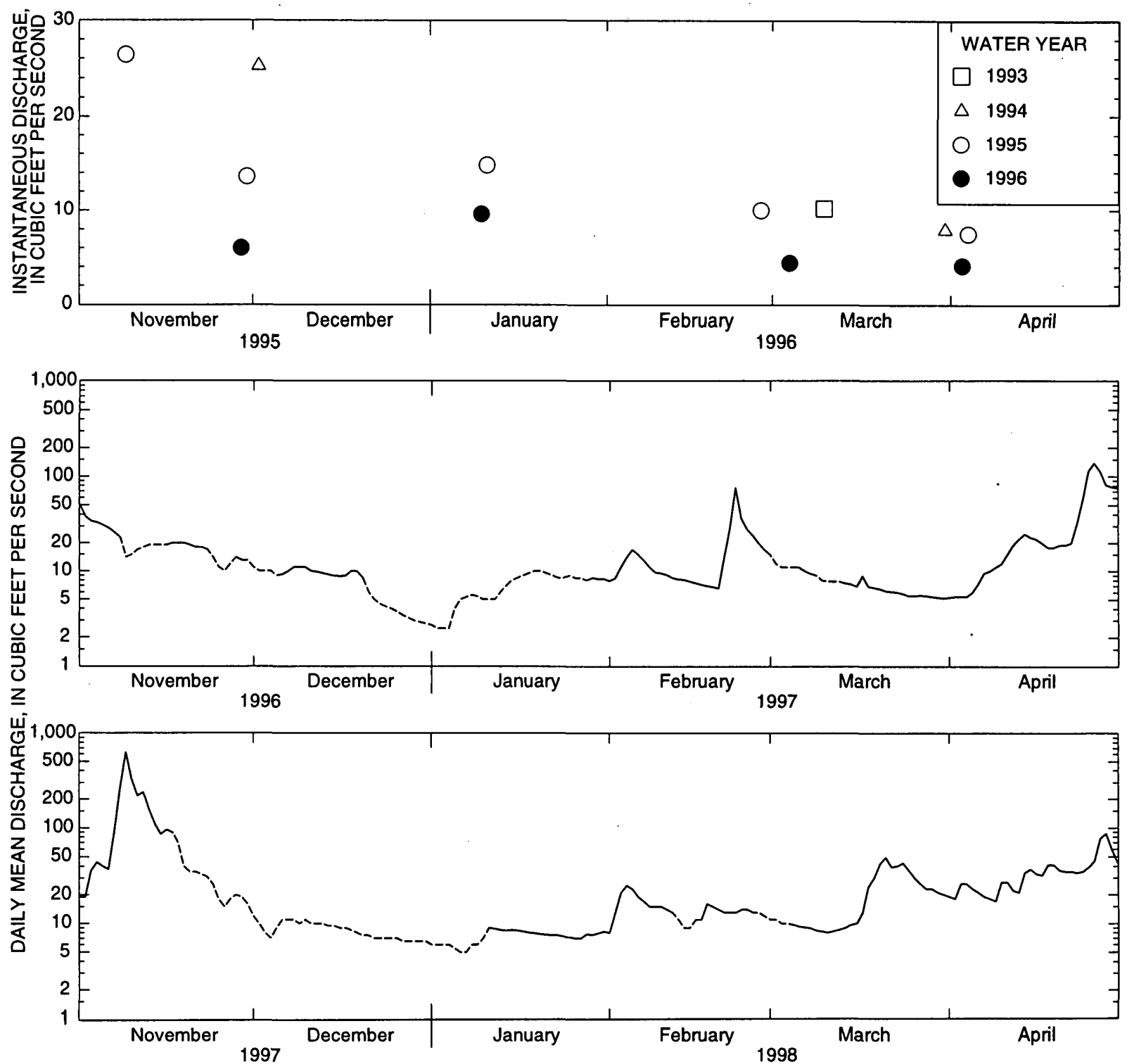

EXPLANATION

Dashed line indicates estimated discharge due to ice formation

Figure 25. Instantaneous discharge measurements and daily mean discharges for Middle Fork Bradley River below North Fork Bradley River (station number 15239060). 
With additional years of data, monthly low-flow frequency curves can be developed to help forecast flow contributions from North and lower Middle Forks Bradley River. Periodic discharge measurements through the winter, used in conjunction with frequency curves, should improve accuracy of forecasted flows. Because winter base flow is heavily influenced by ground-water contributions, given enough years of data, monthly rates of decreases in discharge may be calculated to further aid in flow forecasting.

Specific conductance measurements were made at the same time as discharge measurements (Rickman, 1995, 1996, 1998) to determine if a relation existed between river discharge and specific conductance (Riggs, 1972; Miller and others, 1988). No discernible relation was apparent between discharge and specific conductance at this site.

\section{SUMMARY}

The lower Bradley River between Bear Island and Lower Riffle Reach provides most of the spawning and incubation habitat for five species of Pacific salmon and Dolly Varden char. FERC licensing requires maintenance of a minimum flow of $40 \mathrm{ft}^{3} / \mathrm{s}$ from November 2 to April 30 to ensure adequate flow for incubation habitat. The $40 \mathrm{ft}^{3} / \mathrm{s}$ minimum is based on an open-water instream flow study, and does not account for intermittent ice formation, which is common in the winter months. Consecutive days of ice formation, measured at the streamgaging station Bradley River near Tidewater, ranged from 1 to 75 . For this report, river icing has been broken down into three phases: forming, stable, and eroding. Stream discharge averaged $57 \mathrm{ft}^{3} / \mathrm{s}$ for the study period, March to April 1993, and November 1 through April 30, 1994-95; this discharge was well above the target flow of $40 \mathrm{ft}^{3} / \mathrm{s}$. The study period was extended to collect data closer to the target flow. Stream discharge for November 1 to April
$30,1996-98$ averaged $49 \mathrm{ft}^{3} / \mathrm{s}$. Ice conditions ranged from ice free to 100 percent ice cover. Hydrologic and water-quality data were collected for a range of discharge, percent ice covers, and icing phases.

Hydrostatic head was higher for all ice conditions than that predicted using the openwater instream flow model, and-on the basis of habitat suitability criteria-is adequate for discharges as low as $30 \mathrm{ft}^{3} / \mathrm{s}$. Mean surfacewater velocities (non-tide affected) were adequate at $40 \mathrm{ft}^{3} / \mathrm{s}$ for all but one episode of forming ice conditions. At times, the presence of anchor ice decreased the mean velocity to less than $0.5 \mathrm{ft} / \mathrm{s}$. Increased hydrostatic pressure may offset the effects of the slower velocities with respect to surface- and intragravel-water exchange and intragravel-water velocity. Velocity is the limiting factor governing longterm minimum discharge limits. The long-term minimum discharge needed to ensure adequate incubation habitat, based on mean velocity alone, is $40 \mathrm{ft}^{3} / \mathrm{s}$ for ice-forming conditions, 35 $\mathrm{ft}^{3} / \mathrm{s}$ for stable and eroding ice conditions, and $30 \mathrm{ft}^{3} / \mathrm{s}$ for ice-free conditions. For periods of rapid decreases in discharge, where ice collapses or becomes bridged, $30 \mathrm{ft}^{3} / \mathrm{s}$ will provide adequate mean velocities. Mean surface-water velocities are slowest during periods of high tide. Velocity distribution within a transect changes drastically with ice formation. Each episode of ice formation causes different and unique velocity distribution. Wetted perimeter does not appear to be a function of discharge for any given type of ice cover. Anchor ice, collapsed ice shelves, and bank scour appear to be the dominant controlling factors for wetted perimeter.

Intragravel-water temperatures were generally 0.5 to $1.0{ }^{\circ} \mathrm{C}$ warmer than those of surface water during the winter months. Changes in surface- and intragravel-water temperature were mostly a function of periodic warm rains and do not seem to be related to discharge. 
Surface-water dissolved-oxygen concentrations are generally larger than those for intragravel water. No clear relations were noted among ice phase, percent ice cover, discharge, and dissolved-oxygen concentrations. Dissolved-oxygen levels exceeded recommended minimum concentration for discharges greater than or equal to $40 \mathrm{ft}^{3} / \mathrm{s}$ and are expected to be adequate for discharges as low as $30 \mathrm{ft}^{3} / \mathrm{s}$ for short periods where fine-sediment deposition is not a factor. Data are not sufficient to estimate intragravel-water dissolved-oxygen concentrations for long periods of discharge less than 40 $\mathrm{ft}^{3} / \mathrm{s}$.

No indication of seawater intrusion was evident from specific conductance measurements made immediately following high tides. The ground-water contribution to total river discharge could not be determined from the specific conductance data. Specific conductance is not a factor for determining the effects of lesser flows on salmon incubation habitat in the lower Bradley River.

Suspended sediment in the lower Bradley River is predominantly smaller than $0.016 \mathrm{~mm}$ diameter. Fine-sediment deposition, based on suspended-sediment particle size analysis and shear velocity calculations, as well as on field observations, is greatest at the Upper and Lower Riffle Reach transects. Significant finesediment deposition occurs at the Upper and Lower Riffle Reach transects during some tide peak recessions. In the absence of tidal effects, streamflow of $40 \mathrm{ft}^{3} / \mathrm{s}$ is adequate to prevent significant fine-sediment deposition in the lower Bradley River. Fine-sediment deposition from unexpected, temporary decreases in flow would not adversely affect salmon incubation habitat. Data are insufficient to determine finesediment deposition potential for long-term flows less than $40 \mathrm{ft}^{3} / \mathrm{s}$. Fine-sediment data from incoming tides would be needed to determine if increased sediment deposition would occur at lower discharges over long time periods.
Dissolved-oxygen interchange percentages are high for all ice conditions and flows noted during this study, and are adequate for the minimum allowable discharge of $40 \mathrm{ft}^{3} / \mathrm{s}$ and short-term flows as low as $30 \mathrm{ft}^{3} / \mathrm{s}$. Data are insufficient for determining the lower limits of long-term streamflow needed to ensure adequate dissolved-oxygen interchange.

The rate of stage change caused by outgoing tide, ice breakup, and a sudden decrease in flow released from the fish-water bypass, was found to be slow enough to not cause significant stranding of juvenile salmon.

Discharge contributions measured at the stream-gaging station Middle Fork below North Fork Bradley River needed to maintain $40 \mathrm{ft}^{3} / \mathrm{s}$ in the lower Bradley River ranged from 6 to 100 percent. Monthly maximum fish-water bypass discharges needed to maintain a minimum flow of $40 \mathrm{ft}^{3} / \mathrm{s}$ in the lower Bradley River were estimated. Additional data are needed to develop frequency curves with which periodic discharge measurements could be used to forecast flow contributions to the lower Bradley River.

\section{CONCLUSIONS}

The minimum allowable discharge of 40 $\mathrm{ft}^{3} / \mathrm{s}$ in the lower Bradley River from November 2 to April 1 provides adequate salmon incubation habitat protection. Stream-water velocity is the limiting factor to ensure habitat protection for flows less than $40 \mathrm{ft}^{3} / \mathrm{s}$. The long-term minimum flow limits could not be determined because the potential for tide-induced fine-sediment deposition with decreased stream-water velocities, is unknown. In the event of sudden decreases in flow, a minimum flow of $30 \mathrm{ft}^{3} / \mathrm{s}$ would adequately protect salmon incubation habitat. Stranding is not a problem for rapid decreases in flow. The discharges that must be released at the fish-water bypass to ensure 40 $\mathrm{ft}^{3} / \mathrm{s}$ in the Lower Bradley River ranged from 0 to $37.5 \mathrm{ft}^{3} / \mathrm{s}$. 


\section{REFERENCES CITED}

Alonso, C.V., and Mendoza, C., 1992, Near-bed sediment concentration in gravel-bedded streams: Water Resources Research, v. 28, no. 9, p. 2459-2468.

American Public Health Association, American Water Works Association, and Water Pollution Control Federation, 1989, Standard methods for the examination of water and wastewater (17th ed.): Washington D.C., 1451 p.

Ashton, G.D., ed., 1986, River and lake ice engineering: Littleton, Colo., Water Resources Publications, $485 \mathrm{p}$.

Baldrige, J.E., and Trihey, E.W., 1982, Potential effects of two alternative hydroelectric developments on the fishery resource of the lower Tazimina River, Alaska: Anchorage, Alaska, Arctic Environmental Information and Data Center, Report for Alaska Power Authority.

Becker, C.D., Neitzel, D.A., and Fickeisen, D.H., 1982, Effects of dewatering on Chinook salmon reddsTolerance of four developmental phases to daily dewatering: Transactions of the American Fisheries Society, v. 111, p. 624-637.

Benson, S.L., Hess, D.L., Meyer, D.F., Peck, K.A., and Swanner, W.C., 1998, Water resources data for Alaska, water year 1997: U.S. Geological Survey Water-Data Report AK-97-1, 306 p

Bigelow, B.B., Bailey, B.J., Hiner, M.M., Schellekens, M.F., and Linn, K.R., 1995, Water resources data for Alaska, water year 1994: U.S. Geological Survey Water-Data Report AK-94-1, 289 p.

Burbank, D.C., 1977, Circulation studies in Kachemak Bay and lower Cook Inlet: Alaska Department of Fish and Game, Anchorage, Alaska, 207 p.

Chapman, D.W., 1988, Critical review of variables used to define effects of fines in redds of large salmonids: Transactions of the American Fisheries Society, v. 117 , p. 1-21.

Chapman, D.W., and McLeod, K.P., 1987, Development of criteria for fine sediment in the Northern Rockies ecoregion: Final report for the U.S. Environmental Protection Agency, Contract No. 68-01-6986, $279 \mathrm{p}$.

Chow, V.T., 1959, Open-channel hydraulics: New York, McGraw-Hill Book Company, Inc., 680 p.

Coble, D.W., 1961, Influence of water exchange and dissolved oxygen in redds on survival of Steelhead Trout embryos: Transactions of the American Fisheries Society, v. 90, p. 469-474.
Daly, S.F., 1981, Prediction of ice growth and circulation in Kachemak Bay, Bradley Lake hydroelectric project: Corps of Engineers, U.S. Army Cold Regions Research and Engineering Laboratory, Hanover, New Hampshire, 62 p.

Fulford, J.M., 1994, User's guide to SAC-A computer program for computing discharge by slope-area method: U.S. Geological Survey Open-File Report 94-360, $30 \mathrm{p}$.

Godin, J.G.J., 1980, Temporal aspects of juvenile pink salmon (Oncorhynchus gorbuscha Walbaum) emergence from simulated gravel redd: Canadian Journal of Zoology, v. 58, p. 735-744.

Groot, C., and Margolis, L.,1991, Pacific salmon life history: Vancouver, Canada, UBC Press, 564 p.

Guy, H.P., 1969, Laboratory theory and methods for sediment analysis: U.S. Geological Survey Techniques of Water Resources Investigations, book 5, chap. $\mathrm{C} 1,58 \mathrm{p}$.

Guy, H.P, and Norman, V.W., 1970, Field methods for measuring fluvial sediment: U.S. Geological Survey Techniques of Water Resources Investigations, book 3, chap. C2, 59 p.

Helsel, D.R., and Hirsch, R.M., 1992, Statistical methods in water resources: New York, Elsevier Science Publishing Company, Inc., 522 p.

Hem, J.D., 1985, Study and interpretation of chemical characteristics of natural water (3d ed.): U.S. Geological Survey Water-Supply Paper 2254, 263 p.

Hoffman, R.J.,1986, A horizontal intragravel pipe for sampling water quality in salmonid spawning gravel: North American Journal of Fisheries Management, v. 6, p. 445-448.

Johnson, R.A., 1980, Oxygen transport in spawning gravels: Canadian Journal of Fisheries and Aquatic Science, v. 37, no. 2, p. 155-162.

Linn, K.R., Kemnitz, R.T., Bailey, B.J., Rickman, R.L., and Swanner, W.C., 1994, Water resources data for Alaska, water year 1993: U.S. Geological Survey Water-Data Report AK-93-1, 373 p.

Linn, K.R., Shaw, S.K., Swanner, W.C., Rickman, R.L., and Schellekens, M.F., 1997, Water resources data for Alaska, water year 1996: U.S. Geological Survey Water-Data Report AK-96-1, 270 p.

Miller, R.L., Bradford, W.L., and Peters, N.E., 1988, Specific conductance-Theoretical considerations, and applications to analytical quality control: U.S. Geological Survey Water-Supply Paper 2311, 16 p. 
Morrow, J.E., 1980, The freshwater fishes of Alaska: Anchorage, Alaska, Alaska Northwest Publishing Company, $248 \mathrm{p}$.

Morsell, John, 1994, Bradley Lake Hydroelectric Project investigation of winter flow conditions required to support salmon egg incubation: Anchorage, Alaska, Northern Ecological Services, 10 p.

Morsell, John, 1996, Bradley River salmon study program-1996, annual report: Anchorage, Alaska, Northern Ecological Services, 23 p.

Morsell, John, 1997, Bradley River salmon study program-1997, annual report: Anchorage, Alaska, Northern Ecological Services, 45 p.

Morsell, John, and Howard, R.L., 1995, Final reportBradley River salmon study program: Anchorage, Alaska, Northern Ecological Services, 59 p.

Morsell, John, Howard, R.L., and Bingham, M.M., 1993, Bradley River salmon escapement monitoring and tailrace attraction studies 1993-Final report: Anchorage, Alaska, Northern Ecological Services, prepared for the Alaska Energy Authority, 71 p.

Prewitt, C.M., and Whitmus, C., 1986, A technique for quantifying effects of daily flow fluctuations on stranding of juvenile salmonids: Colorado State University Instream Flow Chronicle, v. II, no. 4, 8 p.

Rantz, S.E., and others, 1982, Measurement and computation of streamflow: U.S. Geological Survey Water-Supply Paper 2175, 631 p.

Reiser, D.W., and White, R.G., 1981, Influence of streamflow reductions on salmonid embryo development and fry quality: Idaho Water and Energy Resources Research Institute, Report for Office of Water Research and Technology, Washington, D.C., $154 \mathrm{p}$.

Rickman, R.L., 1993, Hydrologic conditions and lowflow investigations of the Lower Bradley River near Homer, Alaska, October 1991 to February 1992: U.S. Geological Survey Open-File Report 93-95, $17 \mathrm{p}$.

Rickman, R.L., 1995, Hydrologic and water-quality data for the lower Bradley River, Alaska, March 1993 to April 1994: U.S. Geological Survey Open-File Report 95-338, 30 p.

Rickman, R.L., 1996, Effect of ice formation and streamflow on salmon incubation habitat in the lower Bradley River, Alaska: U.S. Geological Survey WaterResources Investigations Report 96-4202, 34 p.
Rickman, R.L., 1998, Hydrologic and water-quality data for the lower Bradley River, Alaska, November through April, 1995-98: U.S. Geological Survey Open-File Report 98-385, 38 p.

Riggs, H.C., 1972, Low-flow investigations: U.S. Geological Survey Techniques of Water-Resources Investigations, book 4, chap. B1, $18 \mathrm{p}$.

Rundquist, L.A., and Baldrige, J.E., 1990, Fish habitat considerations, in Ryan, W.L., and Crissman, R.D., eds., Cold regions hydrology and hydraulics: American Society of Civil Engineers Monograph, p. 579. 613.

Rundquist, L.A., Baldrige, J.E., and Joyce, M.R., 1985, Lower Bradley River flow regime and its relation to fish, in Resolving Alaska's water resources conflicts, Proceedings, Alaska Section, American Water Resources Association: Fairbanks, University of Alaska, Institute of Water Resources Report IWR108 , p. 77-88.

Schellekens, M.F., Linn, K.R., Bigelow, B.B., Shaw, S.K., and Hiner, M.M., 1996, Water resources data for Alaska, water year 1995: U.S. Geological Survey Water-Data Report AK-95-1, 278 p.

Shumway, D.L., Warren, C.E., and Doudoroff, P., 1964, Influence of oxygen concentrations and water movement on the growth of steelhead trout and coho salmon embryos: Transactions of the American Fisheries Society v. 93, p. 342-356.

Stevens, H.H., Jr., Ficke, J.F., and Smoot, G.F., 1975, Water temperature-Influential factors, field measurements, and data presentation: U.S. Geological Survey Techniques of Water-Resources Investigations, book 1, chap. D1, 65 p.

U.S. Environmental Protection Agency, 1977, Quality criteria for water, 1976: Washington, D.C., U.S. Government Printing Office, 256 p.

Vaux, W.G., 1968, Intragravel flow and interchange of water in a streambed: Fishery Bulletin, v. 66, no. 3, p. 479-489.

Wickett, W.P., 1954, The oxygen supply to salmon eggs in spawning beds: Journal of the Fisheries Research Board of Canada, v. 11, no. 6, p. 933-953.

Woods, P.F., 1980, Dissolved oxygen in intragravel water of three tributaries to Redwood Creek, Humboldt County, California: American Water Resources Association, Water Resources Bulletin, v. 16, no. 1, p. 105-111.

Woodward-Clyde Consultants, 1983, Bradley River instream flow studies: Anchorage, Alaska, 75 p. 